\title{
Fast Flux Test Facility Final Safety Analysis Report Amendment 72
}

D. A. Gantt

Reactor Electrical/I\&C Engineering

Date Published

August 1992

Prepared for the U.S. Department of Energy Assistant Secretary for Nuclear Energy

\section{Q. Westinghouse P.O. Box 1970 \\ Hanford Company Richland, Washington 99352}

Hanford Operations and Engineering Contractor for the

U.S. Department of Energy under Contract DE-AC06-87RL10930 


\section{DISCLAIMER}

This report was prepared as an account of work sponsored by an agency of the United States Government. Neither the United States Government nor any agency Thereof, nor any of their employees, makes any warranty, express or implied, or assumes any legal liability or responsibility for the accuracy, completeness, or usefulness of any information, apparatus, product, or process disclosed, or represents that its use would not infringe privately owned rights. Reference herein to any specific commercial product, process, or service by trade name, trademark, manufacturer, or otherwise does not necessarily constitute or imply its endorsement, recommendation, or favoring by the United States Government or any agency thereof. The views and opinions of authors expressed herein do not necessarily state or reflect those of the United States Government or any agency thereof. 


\section{DISCLAIMER}

Portions of this document may be illegible in electronic image products. Images are produced from the best available original document. 


\section{LEGAL DISCLAIMER}

This report was prepared as an account of work sponsored by an agency of the United States Government. Neither the United States Government nor any agency thereof, nor any of their employees, nor any of their contractors, subcontractors or their employees, makes any warranty, express or implied, or assumes any legal liability or responsibility for the accuracy, completeness, or any third party's use or the results of such use of any information, apparatus, product, or process disclosed, or represents that its use would not infringe privately owned rights. Reference herein to any specific commercial product, process, or service by trade name, trademark, manufacturer, or otherwise, does not necessarily constitute or imply its endorsement, recommendation, or favoring by the United States Government or any agency thereof or its contractors or subcontractors. The views and opinions of authors expressed herein do not necessarily state or reflect those of the United States Government or any agency thereof.

This report has been reproduced from the best available copy. Available in paper copy and microfiche.

Available to the U.S. Department of Energy and its contractors from

Office of Scientific and Technical Information

P.O. Box 62

Oak Ridge, TN 37831

(615) 576-8401

Printed in the United States of America

DISCL.M-3.CHP (1-91) 


\section{PAGES 1 to 2 WERE INTENTIONALLY LEFT BLANK}




\section{DISCLAMMER}

Portions of this document may be illegible in electronic image products. Images are produced from the best available original document. 


\section{DISCLAIMER}

This report was prepared as an account of work sponsored by an agency of the United States Government. Neither the United States Government nor any agency thereof, nor any of their employees, makes any warranty, express or implied, or assumes any legal liability or responsibility for the accuracy, completeness, or usefulness of any information, apparatus, product, or process disclosed, or represents that its use would not infringe privately owned rights. Reference herein to any specific commercial product, process, or service by trade name, trademark, manufacturer, or otherwise does not necessarily constitute or imply its endorsement, recommendation, or favoring by the United States Government or any agency thereof. The views and opinions of authors expressed herein do not necessarily state or reflect those of the United States Government or any agency thereof. 
WHC-TI-75002-Amend. 12

Document Title: Fast Flux Test Facility Final Safety Analysis Report (Amendment 72)

Prepared by:

Approved by:

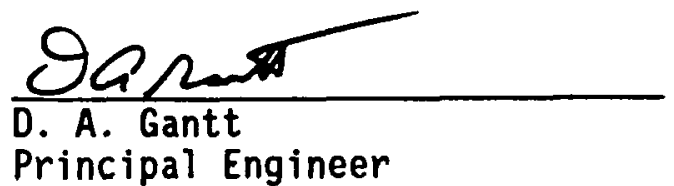

Principal Engineer

5.7. Crow

S. H. Crow, Manager

Reactor Electrical/I\&C Engineering

Approved by:

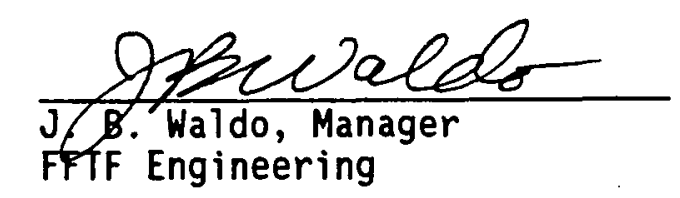

FF fF Engineering $\frac{7-3 /-92}{\text { Date }}$

$\frac{8 / 3 / 92}{\text { Date }}$

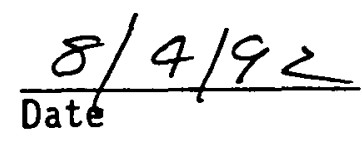

v 


\begin{tabular}{|c|c|c|c|}
\hline ACTION & DATE & CHANGE & APPROVAL \\
\hline Amendment 71 & $10 / 25 / 91$ & 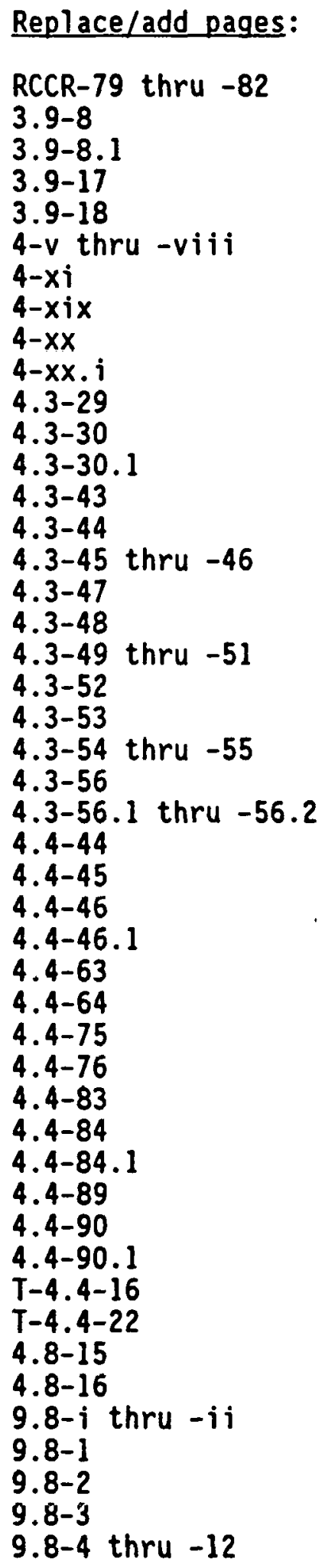 & $\begin{array}{l}\text { Engineering Change Notices: } \\
\text { New Page } \\
\text { ECN 152427 } \\
\text { Text Rotation, New Page } \\
\text { Text Rotation } \\
\text { ECN 152427 } \\
\text { Update } \\
\text { Update } \\
\text { Editorial } \\
\text { Update, Text Rotation } \\
\text { Text Rotation, New Page } \\
\text { Editorial, Text Rotation } \\
\text { ECN 108897, Text Rotation } \\
\text { Text Rotation, New Page } \\
\text { ECN 108897, Editorial } \\
\text { Text Rotation, Editorial } \\
\text { Text Rotation } \\
\text { Editorial } \\
\text { ECN 108897, Text Rotation } \\
\text { Text Rotation } \\
\text { Editorial, Text Rotation } \\
\text { ECN 108897, Text Rotation } \\
\text { Text Rotation } \\
\text { ECN 108897, Text Rotation } \\
\text { Text Rotation, New Page } \\
\text { Text Rotation } \\
\text { ECN 108897, Text Rotation } \\
\text { Text Rotation, Editorial } \\
\text { Text Rotation, Editorial } \\
\text { Text Rotation } \\
\text { ECN 108897, Text Rotation } \\
\text { Editorial } \\
\text { ECN 108897, Editorial } \\
\text { ECN lo8897, Text Rotation } \\
\text { Editorial, Text Rot Page } \\
\text { Text Rotation, New } \\
\text { ECN 108897 } \\
\text { Text Rotation, Editorial } \\
\text { Text Rotation, New Page } \\
\text { ECN 108897 } \\
\text { ECN 108897 } \\
\text { Text Rotation } \\
\text { ECN 108897 } \\
\text { Update } \\
\text { Editorial } \\
\text { ECN 148446 } \\
\text { Text Rotation } \\
\text { ECN 148446 }\end{array}$ \\
\hline & & RCCR-79 & $\begin{array}{l}\text { Amendment } 71,10 / 25 / 91 \\
\text { New Page }\end{array}$ \\
\hline
\end{tabular}


FFTF FINAL SAFETY ANALYSIS REPORT

RELEASE AND CHANGE CONTROL RECORD

\begin{tabular}{|c|c|c|c|}
\hline ACTION & DATE & CHANGE & APPROVAL \\
\hline \multirow{4}{*}{$\begin{array}{l}\text { Amendment } 71 \\
\text { (Cont inued) }\end{array}$} & $10 / 25 / 91$ & Replace/add pages: & Engineering Change Notices: \\
\hline & & $\frac{\text { Remove page: }}{9.8-8.1}$ & ECN 148446 \\
\hline & - & $\begin{array}{l}\text { Replace/add pages: } \\
9.8-13 \\
9.8-14 \\
9.8-15 \text { thru }-16 \\
9.8-17 \text { thru }-20 \\
9.8-21 \\
\text { T-9.8-1 } \\
\text { T-9.8-2 } \\
\text { T-9.8-3 } \\
\text { F-9.8-1 } \\
11.11-\text { i } \\
11.11-11 \\
11.11-12 \text { thru }-14 \\
15.0-j i \\
15.1 .3-23 \text { thru }-24 \\
15.1 .3-24.1 \\
T-15.1 .3-2 \\
13.1 .5-3 \text { thru }-4 \\
T-16.2-11 \\
T-16.2-12 \\
17-i \\
17-i \text { i } \\
17-x \\
17-6 \text { thru }-7 \\
17-8 \\
17-8.1 \\
17-47 \\
17-56 \\
17-184 \text { thru }-185 \\
17-199 \text { thru }-200 \\
17-200.1 \\
17-211 \text { thru }-213 \\
17-250 \text { thru }-252 \\
17-253 \\
17-264 \\
17-274 \\
17-322 \\
17-323 \\
17-334 \\
17-343 \\
17-344 \\
17-352 \\
17-354 \text { thru }-356\end{array}$ & $\begin{array}{l}\text { Editorial } \\
\text { Text Rotation } \\
\text { Editorial } \\
\text { ECN 148446 } \\
\text { ECN 148446, New Page } \\
\text { Editorial } \\
\text { ECN 148446, } \\
\text { Text Rotation, New Page } \\
\text { ECN 148446 } \\
\text { Update } \\
\text { ECN 122931 } \\
\text { Text Rotation } \\
\text { Update } \\
\text { ECN 122933 } \\
\text { Text Rotation, New Page } \\
\text { ECN 122933 } \\
\text { ECN 122933 } \\
\text { ECN 137781 } \\
\text { Editoria1 } \\
\text { ECN 127611 } \\
\text { ECN 127476, Updato } \\
\text { Updale } \\
\text { ECN 127611 } \\
\text { Text Rotation } \\
\text { Text Rotation, New Page } \\
\text { ECN 127611 } \\
\text { ECN 108897 } \\
\text { ECN 127667, Editorial } \\
\text { ECN 122711 } \\
\text { ECN 122711, New Page } \\
\text { ECN 136326 } \\
\text { ECN 141809 } \\
\text { Text Rotation } \\
\text { ECN 127611 } \\
\text { ECN 127611 } \\
\text { ECN 127611 } \\
\text { Text. Rotation } \\
\text { ECN 127611 } \\
\text { Text Rotation } \\
\text { ECN 127667 } \\
\text { ECN 127611 } \\
\text { ECN 127611 }\end{array}$ \\
\hline & & RCCR-80 & $\begin{array}{l}\text { Amendment } 72,08 / 15 / 92 \\
\text { Typo }\end{array}$ \\
\hline
\end{tabular}


FFTF FINAL SAFETY ANALYSIS REPORT

RELEASE AND CHANGE CONTROL RECORD

\begin{tabular}{|c|c|c|c|}
\hline ACTION & DATE & CHANGE & APPROVAL \\
\hline $\begin{array}{l}\text { Amendment } 71 \\
\text { (Continued) }\end{array}$ & $10 / 25 / 91$ & 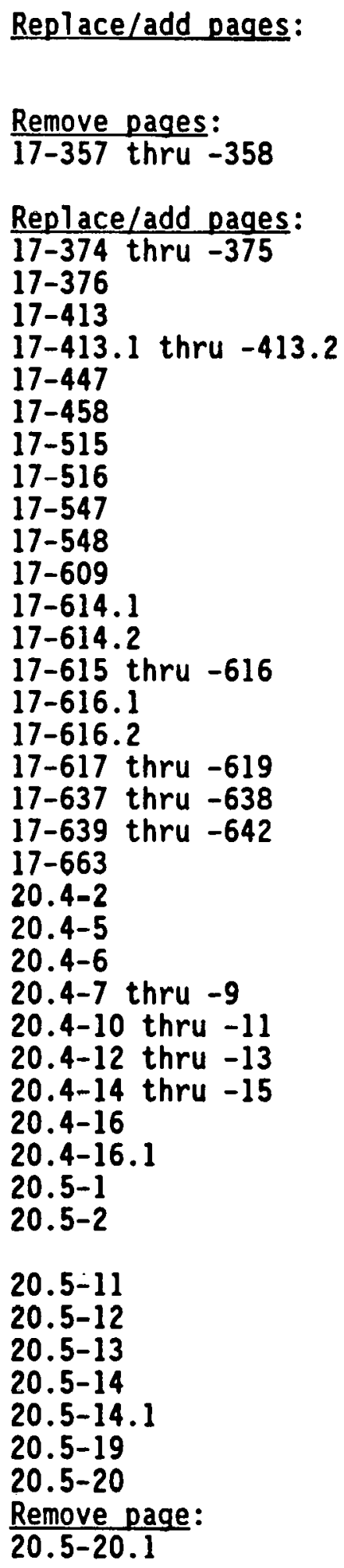 & $\begin{array}{l}\text { ECN } 108897 \\
\text { Editorial } \\
\text { ECN 122705 } \\
\text { ECN 122705, New Page } \\
\text { ECN 141852 } \\
\text { ECN 141852 } \\
\text { ECN } 152401 \\
\text { Editorial } \\
\text { Text Rotation } \\
\text { ECN 127667 } \\
\text { ECN 122711 } \\
\text { ECN 122711, Text Rotation } \\
\text { Text Rotation } \\
\text { ECN 122711 } \\
\text { ECN 122711 } \\
\text { Text Rotation } \\
\text { ECN 122711 } \\
\text { ECN 136326 } \\
\text { Text Rotation } \\
\text { ECN 122711, 136326, los897 } \\
\text { ECN 148447 } \\
\text { Editorial, Text Rotation } \\
\text { Text Rotation } \\
\text { ECN 148447 } \\
\text { ECN 148447, Text Rotation } \\
\text { Text Rotation } \\
\text { ECN 148447, Text Rotation } \\
\text { Text Rotation, Editorial } \\
\text { Text Rotation, New Page } \\
\text { Editorial, Text Rotation } \\
\text { ECN 148447, Editorial, } \\
\text { Text Rotation } \\
\text { Editorial } \\
\text { ECN 148447 } \\
\text { Text Rotation } \\
\text { ECN 148447, Text Rotation } \\
\text { Text Rotation, New Page } \\
\text { ECN 148447 } \\
\text { Text Rotation } \\
\text { ECN 148447 }\end{array}$ \\
\hline & & RCCR-81 & $\begin{array}{l}\text { Amendment } 71,10 / 25 / 91 \\
\text { New Page }\end{array}$ \\
\hline
\end{tabular}


FFTF FINAL SAFETY ANALYSIS REPORT

RELEASE AND CHANGE CONTROL RECORD

\begin{tabular}{|c|c|c|c|}
\hline ACTION & DATE & CHANGE & APPROVAL \\
\hline \multirow{5}{*}{$\begin{array}{l}\text { Amendment } 71 \\
\text { (Cont inued) }\end{array}$} & $10 / 25 / 91$ & Replace/add pages: & Engineering Change Notices: \\
\hline & & $\begin{array}{l}20.5-22 \\
20.5-23 \text { thru }-24 \\
20.5-24.1\end{array}$ & $\begin{array}{l}\text { ECN } 148447 \\
\text { ECN 148447, Text Rotation } \\
\text { Text Rotation, New Page }\end{array}$ \\
\hline & & $\begin{array}{l}\text { Appendix } F \\
\text { F-iii thru }-i v \\
F \cdot 4 \cdot 2-31 \\
F \cdot 4 \cdot 2-32 \text { thru }-33 \\
F \cdot 4 \cdot 2-34 \text { thru }-38 \\
F \cdot 4 \cdot 2-44 \\
T-F \cdot 4-15\end{array}$ & $\begin{array}{l}\text { Update } \\
\text { Editorial } \\
\text { ECN 122933, Text Rotation } \\
\text { Text Rotation } \\
\text { ECN } 122933 \\
\text { ECN } 122933\end{array}$ \\
\hline & : & $\begin{array}{l}\text { Addendum } 2 \text { to Appendix } F \\
\text { F.A2-i i i thru }=i v \\
\text { F.A2-1 thru }-9 \\
\text { F.A2-12 thru }-17 \\
\text { F.A2-18 } \\
\text { F.A2-19 thru }-20 \\
\text { T-F.A2-1 thru }-4 \\
\text { F-F.A2-1 }\end{array}$ & $\begin{array}{l}\text { E } \\
\text { Update } \\
\text { ECN } 127613 \\
\text { ECN } 127613 \\
\text { Text Rotation } \\
\text { ECN 127613, New Page } \\
\text { ECN 127613 } \\
\text { Update }\end{array}$ \\
\hline & & $\begin{array}{l}\text { Remove page: } \\
F-F \cdot A 2-2\end{array}$ & ECN 127613 \\
\hline
\end{tabular}

Amendment $7208 / 15 / 92 \quad$ Renlace/add pagos:

RCCR-80

RCCR-82

RCCR-83 thru -85

12.1-i

2.1-iv

2.2-3 thru -6

Remove page:

F-2.2-1

Replace/add pages:

2.6-3 thru -4

3.0-iij

3.0-iv

3.0-xi

3.2-i thru $-i i$
Engineering Change Notices:

Typo

Update

New Page

Update

Update

ECN 170342

ECN 170342

ECN 170342

Update

ECN 170423

Update

Update 
FFTF FINAL SAFETY ANALYSIS REPORT

RELEASE AND CHANGE CONTROL RECORD

\begin{tabular}{|c|c|c|c|}
\hline ACTION & DATE & CHANGE & APPROVAL \\
\hline \multirow{2}{*}{$\begin{array}{l}\text { Amendment } 72 \\
\text { (Continued) }\end{array}$} & $08 / 15 / 92$ & Replace/add pages: & Engineering Change Notices: \\
\hline & & 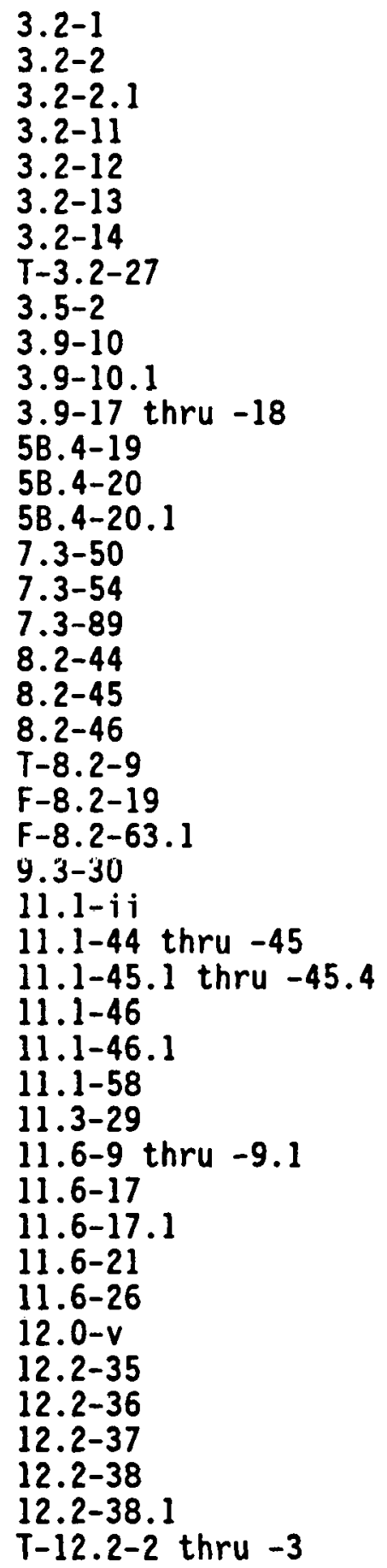 & 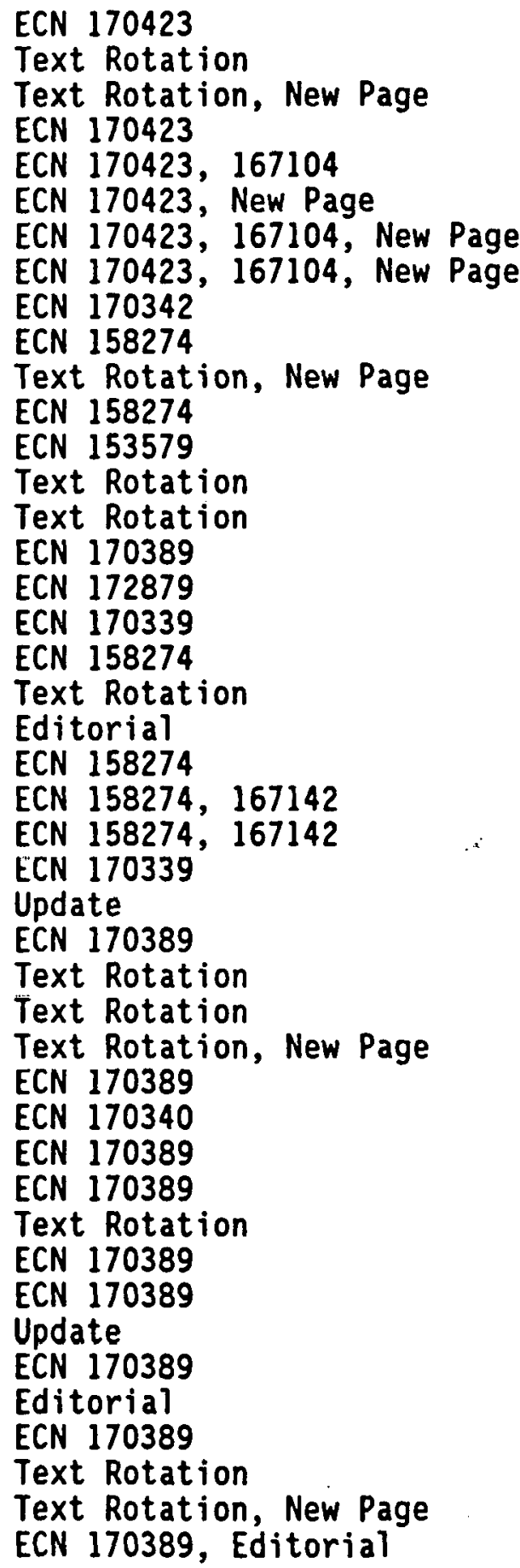 \\
\hline
\end{tabular}




\begin{tabular}{lll}
\hline ACTION & DATE & CHANGE \\
\hline
\end{tabular}

Amendment $7208 / 15 / 92$ Replace/add pages:

Engineering Change Notices: (Continued)

\author{
$T-12.2-4$ \\ 12.3-2 \\ 13.0-i \\ 13.1-11 \\ 13.1-15 thru -16 \\ 13.3-27 \\ $13 \cdot 3-51$ \\ $13.3-68$
}

Remove all existing pages of Chapter 16 and replace with:

16-1 thru -iv

16.1-1 thru -2

16.2.1-1 thru -2

16.2.2-1 thru -4

16.2.3-1 thru -11

16.2.4-1 thru -2

16.2.5-1 thru -4

$16.2 \cdot 6-1$

$16 \cdot 2 \cdot 7-1$

$16.2 .8-1$

16.2.9-1 thru -2

16.2.10/11-1 tiliru -3

16.2.12-1 thru -2

16.2.13-1 thru -2

16.2.14-1

16.2.15-1 thru -2

16.2.16-1

16.2.17-1 thru -2

16.2.18-1

16.2.19-1

T-16.2-1 thru -17

Replace/add pages:

$17-v$
$17-8.1$
$17-9$
$17-178$
$17-186$
$17-212.1$
$17-228$
$17-258$
$17-531$
$17-564$

RCCR-84
Editorial, Text Rotation

ECN 170389

Update

ECN 167052

ECN 167052

ECN 170389

ECN 170309, Editurid

ECN 170389
Update

ECN 137778

ECN 137778

ECN 137778

ECN 137778

ECN 137778

ECN 137778

ECN 137778

ECN 137778

ECN 137778

ECN 137778

ECN 137778

ECN 137778

ECN 137778

ECN 137778

ECN 137778

EC.N 137778

ECN 137778

ECN 137778

ECN 137778

ECN 137778

ECN 158506

Text Rotation

ECN 132411

ECN 141869

ECN 158274

ECN 136326

ECN 168470

ECN 158506

ECN 158535

ECN 158535

Amendment 72, 08/15/92 New Page 
FFTF FINAL SAFETY ANALYSIS REPORT

RELEASE AND CHANGE CONTROL RECORD

ACTION

DATE

CHANGE

APPROVAL

Amendment 72 08/15/92 Replace/add pages: (Cont inued)

\author{
17-581 \\ 17-587 \\ 17-592 \\ 17-620 thru -621 \\ 19.2-4 \\ $19.3 / 4-17$ \\ 20.3-1 thru -3 \\ 20.3-4 \\ 20.4-1 \\ 20.4-2 thru -5 \\ 20.4-6 \\ 20.4-7 \\ 20.4-8 \\ 20.4-11 \\ 20.4-19 \\ 20.5-1 \\ 20.5-2 \\ 20.5-2.1 \\ 20.5-5 thru -6 \\ 20.5-7 thru -8 \\ 20.5-9 \\ 20.5-10 \\ 20.5-11 \\ 20.5-12 \\ 20.5-13 thru -14 \\ 20.5-14.1 \\ $20.5-14.2$ \\ - 20.5-15 \\ 20.5-17
}

Appendix B:
Engineering Change Notices:

ECN 153577

ECN 158535

ECN 158274

ECN 170389

ECN 158280

ECN 158280

ECN 132542

Text Rotation

ECN 167101

ECN 132542

ECN 132542, 167102

ECN 132542

ECN 132542, 167102

ECN 132542

ECN 132542

ECN 132542

Text Rotation

ECN 132542, New Page

ECN 132542

Text Rotation

ECN 132542, 167102,

Text Rotation

ECN 132542, Text Rotation

Text Rotation

ECN 132542, 167102,

Text Rotation

Text Rotation

ECN 132542, Text Rotation

Text Rotation, New Page

ECN 132542

ECN 132542

ECN 170339 


\section{CHAPTER 2.0 \\ SITE CHARACTERISTICS}

CONTENTS

2.1 GEOGRAPHY AND DEMOGRAPHY

Page

2.1.1 Site Location

2.1-1

2.1.2 Site Description

2.1-1

2.1.2.1 Exclusion Area Control

2.1-2

2.1.2.2 Boundaries for Establishing Effluent Release Limits

2.1-2

2.1-3

2.1.3 Population and Population Distribution

2.1-3

2.1.3.1 Population Within Ten Miles and Between Ten and Fifty Miles

2.1-4

2.1.3.2 Low Population Zone

2.1-5

2.1.3.3 Transient Population

2.1-5

2.1.3.4 Population Center

2.1-5

2.1.3.5 Public Facilities and Institutions

2. $1-6$

2.1.4 Uses of. Adjacent Lands and Waters

2.1-6

2.2 NEARBY INDUSTRIAL, TRANSPORTATION, MILITARY FACILITIES

2.2-1

2.2.1 Location

2.2-1

2.2.2 Description

2.2-1

2.2.2.1 Waterways

2.2-3

2.2.2.2 Airports

2.2-3

2.2.2.3 Highways

$2.2-3$

2.2.2.4 Railways

$2.2-4$

2.2.2.5 Projections of Industrial Growth

$2.2-4$

2.2.3 Evaluation of Potential Accidents

2.2-5

2.3 METEOROLOGY

2.3-1

2.3.1 Regional Climatology

2.3-1

2.3.1.1 General Climate

2.3-1

2.3.1.2 Severe Weather

2.3-3

2.3.1.2.1 Criteria for Tornado Design

2.3-5

2.3.1.3 Pollution Potential

2.3-6 
CONTENTS (Cont'd)

2.3.2 Local Meteorology

Page

2.3.2.1 Local and Extreme Values of Meteorological Parameters

2.3-6

2.3.2.2 Potential Influence of the Plant and Its Facilities on Local Meteorology

2.3-6

2.3-7

2.3.3 On-site Meteorological Measurements--Programs

2.3-7

2.3.4 Short Term (Accident) Diffusion Estimates

2.3-8

2.3.5 Long Term (Routine) Diffusion Estimates

2.3-8

2.4 HYDROLOGIC ENGINEERING

2.4-1

2.4.1 Hydrologic Description

2.4-1

2.4.1.1 Site and Facilities

2.4-1

2.4.1.2 Hydrosphere

2.4-1

2.4 .2 Floods

2.4-2

2.4.2.1 Flood History

2.4-2

2.4.2.2 Flood Design Consideration

2.4-3

2.4.3 Potential Dam Failure

2.4-3

2.4.4 Groundwater

2.4-4

2.5 GEOLOGY AND SEISMOLOGY

2. 5-1

2.5.1 Basic Geologic and Seismic Information

2.5-1

2.5.1.1 Regional Geology

2.5-1

2.5.1.2 Site Geology

2. 5-?

2.5.2 Vibratory liround Motion

2.5-2

2.5.3 Surface Faulting

2.5-3

2.5.4 Stability of Subsurface Materials

$2.5-4$

2.5.5 Slope Stability

$2.5-4$

2.6 REFERENCES

2.6-1 


\section{TABLES}

2.1-1 Population Projections

Page

2.1-2 Working and School Populations

T-2.1-1

2.1-3 Projected Population Within 10 Miles of FFTF Site

T-2.1-2

2.1-4 Principal Crops Within 50 Miles of FFTF

T-2.1-3

2.1-5 Fishery in Hanford Area

T-2.1-4

2.2-1 Rail Shipments of Hazardous Materials Via ERDA Owned

2.3-1 Monthly Extremes of Daily Maximum and Minimum Temperatures

$T-2.1-5$ and Daily Temperature Ranges--Hanford Townsite (Near) and HMS Based on Period of Record: 1912-1970

2.3-2 Composite Record of Monthly and Annual Mean Temperatures ( ${ }^{\circ} \mathrm{F}$ ) Hanford Townsite (Near) and HMS: 1912-1970 T-2.3-2

2.3-3 Frequency Distribution in Percent of Dry Bulb Temperature vs Relative Humidity

$T-2.3-4$

2.3-4 Monthly Averages of Psychometric Data Based on Period of Record: . 1950-1970

$T-2.3-6$

2.3-5 Composite Record of Monthly and Annual Precipitation (inches) Hanford Townsite (Near) and HMS: 1912-1970

2.3-6 Average Number of Days with Precipitation of Specified Amount: 1956-1970

T-2.3-9

2.3-7. Monthly and Annual Averages and Extremes in Total Time with Precipitation Observed: 1946-1970

$T-2.3-10$

2.3-8 Total Duration and Maximum Persistence of Fog Tabulated in Hours: 1945-1970

2.3-9 Annual Percent Occurrence of Wind Speed vs Elevation: 1950-1970

$T-2.3-13$

2.3-10 Annual Percent Occurrence of Wind Direction vs Elevation: 1950-1970

$T-2.3-14$

2.3-11 Annual Percent Occurrence of Stability Classes T-2.3-15

2.3-12 Atmospheric Diffusion Factors T-2.3-18

2.3-13 Average Atmospheric Diffusion Factors T-2.3-19

2.3-14 Sector Averaged Annual $X / Q^{\prime}$ 's Beyond Site Boundary T-2.3-20 


\section{FIGURES}

2.1-1 Location of Hanford Reservation

Page

2.1-2 Topography Within 50 Miles of FFTF

F-2.1-1

2.1-3 Area Within 10 Miles of FFTF

$\mathrm{F}-2.1-3$

2.1-4 FFTF Plot Plan

F-2.1-5

2.1-5 Population Distribution About FFTF (1970 Census)

$\mathrm{F}-2.1-7$

2.1-6 Cumulative Population Distribution about FFTF (1970 Census)

$F-2.1-9$

2.3-1 Average Monthly Precipitation Amounts

F-2.1-10

2.4-1 Water Table Map

F-2.3-1

F-2.4-1

2.4-2 Predicted Groundwater Table with Ben Frankl in Dam Construction.

$\mathrm{F}-2.4-2$

2.5-1 Tectonic Map of the Hanford and Adjacent Areas

F-2.5-1 


\subsubsection{Waterways}

Barges of 2,000-3,000 tons capacity can be accommodated on the Columbia River. The manufacturers of large equipment can use barge transportation for delivery. Components must be unloaded at the Port of Benton barge slip, which is located approximately $7 \neq \mathrm{mi}$ from the FFTF. From this point, components will be loaded on DOE-owned or -contracted transportation vehicles for delivery to the site. Hazardous materials (i.e., chemicals, explosives, munitions, or liquid and gaseous fuels) have not been transported by waterways within the Hanford Reservation and approval measures must be met before such shipments can be made.

\subsubsection{Airports}

The Richland Airport, operated by the Port of Benton, is located approximately $8 \frac{1}{2} \mathrm{mi}$ to the south-southeast of the FFTF. The dominant role of the Richland Airport is classified as General Utility. Activities include recreational flying, soaring, and sail plane operations, and parachute jumping and skydiving. Aircraft using the Richland Airport are limited to less than $12,500 \mathrm{lb}$, based on runway ratings.

Activity at the Richland Airport has declined since 1979. In 1979, typical day operations were 170 takeoffs and landings (69,300 operations per year). In 1991, operations had declined to about 70 operations per day $(20,000$ operations per year $)$. Further, the number of aircraft based at the Richland Airport had declined from 65 to 45 . Storage tanks at the airport are 6,000 gal each, one for 80-octane fuel and a second for 100-octane fuel. Based on its present and expected level of operation, the Richland Airport is not considered to present a hazard to the safety of the FFTF.

The Tri-Cities Airport, at Pasco, Washington, is the principal airport in the area for commercial air carriers. The Tri-Cities Airport is located $17 \mathrm{mi}$ to the southeast of the FFTF. Daily operations at the Tri-Cities Airport are about 200 (75,000 operations per year).

\subsubsection{Highways}

The DOE-owned road system serves the areas of the Hanford Site with approximately $270 \mathrm{mi}$ of paved two-lane and four-lane primary roads. State and 
national highway standards prevail for designing and maintaining DOE roads. Figure 2.1-3 shows the primary arteries, both public and DOE-owned, which traverse and/or bypass the site.

Road shipments to and from the Hanford Site 100 Area, 100-N Area, 200 Areas, FFTF, and WPPSS WNP-2 site often use Route 4 (DOE-owned), which passes about $1 \mathrm{mi}$ from the FFTF. The type of materials normally shipped via this route are reagents and chemicals from Central Stores (1100 Area). Commercial shipments of these types of materials are delivered to Central Stores Receiving, close to the city of Richland (\#13 on Figure 2.1-3), or directly to WPPSS WNP-2. Smaller quantities (pounds and gallons) are then transported to the various sites by the Transportation Department on a normal-use or as-needed basis. Gasoline and diesel fuel \#2 are delivered in 4,000- and 6,000-gal tank trucks.

\subsubsection{Railwạs}

The DOE-owned railroad system has a capability of moving approximately 12,000 cars per year over $150 \mathrm{mi}$ of site track. The system includes five main lines and two classification yards and is connected to the Burlington Northern and Union Pacific Lines in the south and to the Chicago, Milwaukee, St. Paul, and Pacific Line in the north. Delivery is usually made to the site Central Stores area in the south with final delivery to the sites by DOE-owned railroad equipment.

Table 2.2-1 identifies the hazardous material types and amounts, and the frequency of shipments transported currently by rail within $2 \frac{1}{2}$ mi of the FFTF site. Increases in the frequency of shipments of chlorine can be expected when the WPPSS reactors come online. As anticipated, however, the shipments will be in 1-ton containers as is presently being transported. The potential hazards of these chlorine shipments are addressed in Section 2.2.3.

\subsubsection{Projections of Industrial Growth}

Within the scope of proposed development for the site, there are no known facilities or industries (with the exception of the WPPSS) unrelated to the FFTF reactor plant operations, planned in the vicinity of the FFTF site. 


\subsubsection{EVALUATION OF POTENTIAL ACCIDENTS}

In general, rail and truck shipments or stored industrial materials do not pose a significant hazard to the FFTF. The shipments are either infrequent, in small quantities, or insufficiently hazardous to present a potential problem. The use of chlorine at the WPPSS, however, did present a possible hazard and was evaluated as to potential consequences at the FFTF site. Because the chlorine is shipped in 1-ton containers, a 1-ton release was postulated (in accordance with the WPPSS evaluation of the problem). ${ }^{(36)}$ The release was assumed to occur on the highway at the closest point to the FFTF (approximately $1 \mathrm{mi}$ ). Under the assumptions of Regulatory Guide $1.78^{(30)}$ and $1.95,{ }^{(35)}$ the maximum concentration of chlorine achieved in the Control Room was $39 \mathrm{mg} / \mathrm{m}^{3}$, thus beneath the limiting value of $45 \mathrm{mg} / \mathrm{m}^{3}$. Accordingly, chlorine does not present an unacceptable hazard at the FFTF.

Operations of the FFTF in the vicinity of local airports, the Richland Airport and the Tri-Cities Airport, do not present an undue risk to the health and safety of the public and meets the limits of 10 CFR 100 applicable to commercial nuclear power plants. The airports are located at sufficient distance and have a sufficiently low number of operations that airport operations aren't a hazard. However, a small number of aircraft entering and leaving the Tri-Cities Airport may be directed on Federal Airways and landing approach routes that pass over or near the FFTF. The probability of such traffic resulting in an impact on FFTF vital areas is less than about $10^{-7}$ per year, ${ }^{(40)}$ which is the limiting, acceptable probability of an aircraft event resulting in consequences exceeding 10 CFR 100 values in NRC Regulatory Guide $1.70^{(41)}$ and NUREG-0800, ${ }^{(42)}$ Section 3.5.1.6.

Potential hazards to the FFTF from radiological accidents were assessed for the $N$ Reactor in the 100-N Area, the waste processing facilities in the 200 Areas, the WPPSS reactors, and the Siemens Nuclear (formerly EXXON) fuel fabrication facility. The $N$ Reactor and the waste processing facility do not pose a hazard because of the distances involved. The Design Basis Accidents (DBA) for the WPPSS reactor, as presented in their Preliminary Safety Analysis Reports, ${ }^{(36,37)}$ were reviewed as to potential hazard at the FFTF site. The worst case found, a Loss of Coolant Accident (LOCA) occurring at either WNP-1 or -4 , hypothetically could yield significant thyroid doses in the vicinity of 
the FFTF. The consequences of this event are mitigated, however, by radiation detectors that automatically isolate the FFTF control room. See Sections 6.4 and $\mathbf{1 5 . 2}$ for further details. Postulated radiological accidents occurring at Siemens Nuclear as addressed in Reference 38 were also assessed as to potential hazard to the FFTF and no problem was found to exist. 
24. Final Soil Investigation Report for Fast Flux Test Facility (Bechtel Corporation), October 1971.

25. Deleted

26. A Summary Report Seismic Evaluation and Development of Ground Acceleration and Response Spectra for FFTF Site, JABE-WADCO-03.

27. Deleted

28. HEDL-TME 71-35, Review of Tornado Considerations for FFTF, January 1971.

29. Deleted

30. Regulatory Guide 1.78, "Assumptions for Evaluating the Habitability of a Nuclear Power Plant Control Room During a Postulated Hazardous Chemical Release," USAEC, June 1974.

31. Deleted

32. AEC Reg. Guide 1.3, "Assumptions Used for Evaluating the Potential Radiological Consequences of a Loss of Coolant Accident for Boiling Water Reactors," Rev. 2, USAEC, June 1974.

33. AEC Reg. Guide 1.4, "Assumptions Used for Evaluating the Potential Radiological Consequences of a Loss of Coolant Accident for Pressurized Water Reactors," Rev. 1, U.S. Atomic Energy Commission, June 1974.

34. D. H. Slade, ed., Meteorology and Atomic Energy--1968, TID-24190, Division of Technical Information, U.S. Atomic Energy Commission, 1968.

35. AEC Regulatory Guide 1.95, "Protection of Nuclear Power Plant Control Room Operator Against an Accidental Chlorine Release, " USNRC, Fébruary 1975.

36. Preliminary Safety Analysis Report, WPPSS Nuclear Projects 1 and 4, Docket \#50-460 and 50-513.

37. Prel iminary Safety Analysis Report, Hanford No. 2, Docket \#50-397.

38. Final Environmental Statement Related to Operation of Uranium Oxide Fuel Plant, EXXON Nuclear Co., Docket \#70-1257, U.S. Atomic Energy Commission, Directorate of Licensing, March 1974.

39. G. W. Spangler, et a1., Description of the COMRADEX Code, Atomic International, AI-67-TDR-108, 1967.

40. D. A. Gantt, Aircraft Hazards to the FFTF, WHC-SD-FF-ER-083, Rev. O, Westinghouse Hanford Company, Richland, Washington, (December 31, 1991). 
41. U.S. Nuclear Regulatory Commission, NRC Regulatory Guide 1.70, Revision 3, "Standard Format and Content of Safety Analysis Reports for Nuclear Power Plants, LWR Edition," November 1978, Washington, D.C.

42. U.S. Nuclear Regulatory Commission, NUREG-0800, U.S. NRC Standard Review Plan, Section 3.5.1.6, "Aircraft Hazards," July 1981, Washington, D.C. 
3.1.7.7 Criterion 43 - Accident Aggravation Prevention

3.1.7.8 Criteria 44 and 45 - Emergency Core Cooling

3.1.7.9 Criteria 46, 47 and 48 - Testing of Emergency Core

Cooling Provisions
C

$3.1-46$

3.1.7.10 Criterion 50 - NDTT Requirements for Containment Material

3.1-46

3.1.7.11 Criterion 51 - Reactor Coolant Pressure Boundary Outside Containment

3.1-47

3.1.7.12 Criterion 52 - Containment Heat Removal Systems

3.1-47

3.1.7.13 Criterion 53 - Containment Isolation Valves

$3.1-48$

3.1.7.14 Criterion 54 - Containment Leakage Rate Testing

$3.1-49.1$

3.1.7.15 Criterion 55 - Containment Periodic Leakage Rate Testing

$3.1-50$

3.1.7.16 Criterion 56 - Provisions for Testing of Penetrations

$3.1-50$

3.1.7.17 Criterion 57 - Provisions for Testing of Isolation Valves

$3.1-50$

3.1.7.18 Deleted Criteria

$3.1-51$

3.1.7.19 Criteria 62 through 65 - Containment Atmosphere Cleanup Systems

3.1-52

3.1-52

3.1.8 Fuel and Waste Storage Systems

3.1-52

3.1.8.1 Criterion 66 - Prevention of Fuel Storage Criticality

$3.1-54$

3.1.8.2 Criterion 67 - Fuel and Waste Storage Decay Heat

3.1 .55

3.1.8.3 Criterion 68 - Fuel and Waste Storage Radiation Shielding

3.1.8.4 Criterion 69 - Protection Against Radioactivity Release from Spent Fuel and Waste Storage

3.1-56

3.1-57

3.1.9 Plant Effluents

3.1-57 Control of Releases
to the Environment

$3.1-59$

3.1.10 Fuel and Test Assembly Handling Systems

3.1.10.1 Criterion 71 - Cooling Systems for Core Component and Test Assembly Handling Equipment

3.1-59 
3.2 Classification of Structures, Equipment and Systems

3.2.1 Seismic Classification

3.2.1.1 Seismic Classification Criteria

3.2.1.2 Seismic Requirements

3.2.2 System Quality Group Classification

3.2.2.1 Quality Group Classification Criteria

3.2.2.2 Code Requirements

$3.2-6$

3.2.3 Safety Classifications

$3.2-11$

3.2.4 References

$3.2-11$

3.2 .14

3.3 Wind and Tornado Loadings

3.3.1 Wind Loadings

3.3.1.1 Design Wind Velocity

3.3.1.2 Vertical Velocity Distribution and Gust Factor

3.3.1.3 Determination of Applied Forces

3.3.2 Tornado Loadings

3.3.2.1 Design Parameters

3.3.2.2 Determination of Forces on Structures

3.3.2.2.1 Wind Pressure Calculation, Load Combination and Stress Limits

3.3.2.3 Ability of Hardened Structures to Perform Despite Failure of Structures Not Designed for Tornado Loads

3.3.3 Tornado Effects

3.3-5

3.3.4 References

3.3-6

3.4 Water Level Design

3.5 Missile Protection

3.5.1 Missile Barriers and Loading 3.5-1

3.5.2 Missile Selection

$3.5-2$

3.5.2.1 External Missiles

$3.5-2$

3.5.2.2 Internal Missiles

$3.5-3$ 


\section{TABLES}

Table

Page

3.2-1 Classification of Structures, Systems and Components

T-3.2-1

3.2-2 Quality Standards vs Minimum Code Requirements

$\mathrm{T}-3.2-26$

3.2-3 FSAR Systems and Phrases Equivalent to "Safety Class"

$\mathrm{T}-3.2-27$

3.6-1 Steel Liner Design for Major Equipment Cells

Containing Primary Sodium Systems

T-3.6-1

3.7-1 Standard Format Cross Index

T-3.7-1

3.7-2 Embedment Conditions of Category I Buildings and Structures

$T-3.7-2$

3.7-3 Index for Seismic Qualification

$\mathrm{T}-3.7-3$

3.9-1 Seismic Category I Equipment

T-3.9-1

3.10-1 Rooms Containing Active Safety Related Equipment

T-3.10-1

3.10-2 Environmental Conditions - In-Containment Inerted Cells

$\mathrm{T}-3.10-6$

3.10-3 Environmental Conditions - In-Containment Air Cells

$T-3 \cdot 10-11$

3.10-4 Environmental Conditions - Ex-Containment

$T-3.10-14$

3.10-5 Environmental Qualifications of Mechanical and Electrical Equipment

$\mathrm{T}-3 \cdot 10-22$

3.10-6 FFTF Valve Environmental Qualification

$\mathrm{T}-3.10-62$

3.10-7 Environmental Qualifications of Mechanical and Electrical Equipment

$T-3 \cdot 10-72$

3.10-8 Systems and Equipment Required to Function After an HCDA

T-3. 10-108

T-3.10-109

3.10-9 Radiation Level Qualification of Electrical Equipment Equipment

$\mathrm{T}-3.10-138$

Related Equipment

$T-3.10-143$ Equipment

$\mathrm{T}-3.10-148$

3.10-13 Instrumentation and Electrical Equipment to Be Qualified by Test 


\section{FIGURES}

Figure

Page

3.2-1 Seismic Category I Piping and Instrument Drawing (P\&ID) Index

$F-3.2-1$

3.5-1 Above Grade Tornado Hardened Structures F-3.5-1

3.5-2 Missile Barrier Features for Containment Building (\#405)

$F-3.5-2$

3.5-3 Missile Barrier Features for DHX Structure - East (\#408-A)

F-3.5-3

3.5-4 Missile Barrier Features for Reactor Service Building ( $\# 4717$ )

F-3.5-4

3.5-5 Missile Barrier Features for Control Building (\#4703) and Auxiliary Equipment Building - East (\#4621-E)

F-3.5-5

3.5-6 Missile Barrier Features for Auxiliary Equipment Building - West (\#4621-W)

$F-3.5-6$

3.5-7 Missile Barrier Features for Heat Transport Service Buildings - East and West (\#491-E and $-W$ ) F-3.5-7

3.5-8 Missile Barrier Features for HTS - South Building (\#491-S)

$F-3.5-8$

3.9-1 DBE Horizontal Response Spectrum at Elevation 550'-0", Ex-Containment

F-3.9-1

3.9-2 DBE Vertical Global Response Spectrum, Ex-Containment F-3.9-2

3.9-3 Control Accelerometer Plots Battery Test F-3.9-3

3.10-1 Post-HCDA Radiation Levels F-3.10-1 


\section{SECTION 3.2 \\ CONTENTS}

3.2 Classification of Structures, Equipment and Systems

Page

3.2.1 Seismic Classification

$3.2-1$

3.2.1.1 Seismic Classification Criteria

$3.2-1$

3.2.1.2 Seismic Requirements

$3.2-1$

3.2.2 System Quality Group Classification

$3.2-3$

3.2.2.1 Quality Group Classification Criteria

$3.2-5$

3.2.2.2 Code Requirements

3.2-6

3.2-11

3.2.3 Safety Classifications

$3.2-11$

3.2.4 References

3.2-14 


\section{TABLES}

3.2-1 Classification of Structures, Systems and Components

Page

3.2-2 Quality Standards vs. Minimum Code Requirements

$\mathrm{T}-3.2-1$

3.2-3 FSAR Systems and Phrases Equivalent to "Safety Class"

$T-3.2-26$

$\mathrm{T}-3.2-27$ 


\subsection{CLASSIFICATION OF STRUCTURES, EQUIPMENT AND SYSTEMS}

This section lists the Fast Flux Test Facility (FFTF) safety-related structures, equipment, and systems and the seismic and quality-related design requirements $\mathrm{placed}$ on them by the FFTF Project. These design requirements are then compared to the minimum requirements recommended by the applicable licensing documents, 10 CFR Parts 50 and 100, and their respective U.S. Nuclear Regulatory Commission (NRC) regulatory guides, as interpreted by the FFTF for a sodium-cooled reactor. In most cases, the regulatory guides for light-water-cooled reactors could be applied directly to the FFTF. In other cases where a described item was not duplicated on the FFTF, the intent of the requirements was compared against whatever FFTF item performed a similar function. Nonsafety-related FFTF structures, equipment, and systems are not covered in this section. Equivalent-graded Safety $\mathrm{Classes}$ for the safety-oriented nomenclature used throughout this FSAR are addressed in Section 3.2.3.

\subsubsection{SEISMIC CLASSIFICATION}

This section identifies by tabulation those FFTF structures, systems, and components that are safety related and designated Seismic Category I. Detailed descriptions of the specific items and their design can be found in the Final Safety Analysis Report (FSAR) systems sections and the System Design Descriptions (SDD).

\subsubsection{Soismic Classification Criteria}

Those FFTF structures, systems, and components important to safety, including their foundations and supports, are designated Seismic Category I and are designed to remain functional in the event of a Design Basis Earthquake (DBE) (equivalent to a Safe Shutdown Earthquake). These plant features are those necessary to ensure (1) the integrity of the reactor coolant pressure boundary, (2) the capability to shut down the reactor and maintain it in a safe shutdown condition, and/or (3) the capability to prevent or mitigate the consequences of accidents that could result in potential offsite exposure comparable to the guideline exposures of 10 CFR Part 100. 
The FFTF features that differ from those discussed for light-water-cooled reactors in NRC Regulatory Guide 1.29, are as follows:

A. In the FFTF a separate "emergency core cooling system" for removing core decay heat does not exist. This function is performed by the Seismic Category I Reactor Heat Transport System (HTS). With respect to seismic requirements, the three HTS loops and their guard pipes and guard vessels provide redundancy. The emergency core cooling system (ECCS) function can be performed by convective flow without electric power to the HTS pumps (see Section 5B.4.2.6).

B. The FFTF Closed Loop Systems (CLS) are considered, for classification purposes, as separate, integral reactor systems. The ECCS function is performed by the reactor HTS, i.e., heat is transferred from the fue 1 test assemblies through the Closed Loop In-Reactor Assembly (CLIRA) to the reactor coolant within the reactor vessel under ECCS conditions (see Section $15 \cdot 1.7 \cdot 2 \cdot 4.3)$.

C. Although a HEPA particulate filtering loop is provided in the containment air exhaust, the FFTF does not have a containment atmosphere cleanup system for radioactivity source reduction because it is not needed for safe shutdown mitigation of offsite doses. In the event of significant releases of radionuclides, the containment is isolable until such time as fallout, plateout, and decay mechanisms reduce the activity levels to allow entry and decontamination.

D. Active heat removal systems are not needed for the containment because the containment is designed to withstand the pressures and temperatures of all identified accidents without service cooling systems (SDD-23 and $S D D-25$ ).

E. The FFTF is designed so that loss of all offsite and diesel electrical power will not preclude a safe shutdown. All safety-related instruments, monitoring instruments, and equipment needed by control personnel for a safe shutdown are powered by Seismic Category I storage batteries and power transformation and distribution systems. Certain Seismic 
Category I valves, control room ventilation solenoids for dampers, and fan control contactors are not supplied with $1 E$ electric power, but they are in or are moved to a safe position on loss of power.

F. Spent fuel, contained in the Interim Decay Storage (IDS) Tank, is normally cooled by one of two independent systems, both requiring electrical power. After an earthquake and subsequent loss of all offsite 
E. Certain portions of the System 82 Radioactive Argon Processing System (RAPS) and Cell Atmosphere Processing System (CAPS) (see H-4-11056 and $\mathrm{H}-4-11090)$, which are normally nonradioactive, could contain considerable inventories of radioactive gas under abnormal conditions. Although the piping and filters (F-57 and F-58) are listed as ANSI B31.1 and ASME Section VIII, respectively, the discussion above in Part (A) applies to these items also, and they are considered equivalent to Section III, Class 3. All bellows seal valves in this piping were procured to Section III, Class 1, as part of the standardization program on this type of valve.

\subsubsection{Code Requirements}

The minimum code requirements applicable to each quality group classification are identified in Table 3.2-2 and correspond to those indicated in Article 50.55a of 10 CFR 50 and NRC Regulatory Guide 1.26. These minimum quality group classifications can be compared to the design codes applied by the FFTF Project.for safety-related systems, or portions of systems, in Table 3.2-1. Because of the high reliability/availability needed for a test reactor, the codes and standards applied to the FFTF sodium and gas systems normally exceed the minimum requirements (see Table 3.2-1, Part B, Systems 51, $61,81,82$, and 85).

For 11 lustrative purposes, key FFTF P\&IDs are included in a separate document described in Figure 3.2-1. The latest revision of each P\&ID is maintained by Engineering Configuration Management. The actual design codes used for the piping systems are shown on the P\&IDs, where each length of pipe is letter designated to indicate (a) design pressure, (b) pipe material, and (c) design code classification. The letter designation used on FFTF P\&IDs to indicate code class is identical to that used by the Regulatory Guide (see Table 3.2-2).

\subsubsection{SAFETY CLASSIFICATIONS}

The final design and construction of the FFTF were completed in the 1970s. The safety-oriented nomenclature that was used to ensure that the plant was 
built and operated according to the specific safety requirements is different from the graded Safety Classes used in the nuclear industry in the 1990s.'

Table 3.2-3 lists the broad systems and phrases used throughout this FSAR that can be assigned an equivalent Safety Class. The FFTF hardware items are assigned Safety Classes in the FFTF Master Information and Data Acquisition System (MIDAS) computer 1 ist $^{2} /$ job control system (JCS)..$^{5}$ This information is used in maintenance, repair, and procurement activities to establish quality requirements that support the unique performance requirements as well as the assumptions and conclusions in the Safety Analyses.

Definitions of the four Safety $C l a s \operatorname{ses}^{1}$ are given below.

1. Safety class $1(\mathrm{SC} 1)$ is the highest classification. The purpose in applying this designator is to ensure that sufficient quality and environmental requirements are met to:

a. Protect the offsite public from receiving a radioactivity dose in excess of 0.5 rem effective dose equivalent (EDE) (excluding ingestion) from credible, postulated accidents that are analyzed in the FSAR

b. Protect the offsite public from receiving an airborne concentration of nonradioactive hazardous material in excess of the applicable toxic chemical limit in the Emergency Response Planning Guidelines No. 2 $(E R P G-2)^{3}$ or in other relevant guides for those toxic chemicals that are not listed in the ERPG

c. Protect the environment from damage to onsite and offsite rivers, lakes, or groundwater from dispersible radioactive materials or nonradioactive hazardous materials, where the Environmental Hazard Safety Classification (EHSC) ${ }^{1}$ number is equal to or greater than $10^{6}$

d. Protect the environment from damage to offsite soil from radioactive airborne discharges which result in contamination that is greater than 20 times the threshold concentrations listed in WHC-CM-7-5. ${ }^{4}$

The offsite public is assumed to be located at the site boundary that is $4.5 \mathrm{mi}$ from the FFTF. NOTE: The FFTF FSAR accident analyses conservatively verified that potential doses at a control distance of $1.5 \mathrm{mi}$ were less than the 10 CFR 100 limits for the Site boundary. 
2. Safety $\mathrm{Class} 2$ (SC2) ensures that sufficient quality and environmental requirements are met to:

a. Protect the onsite worker ${ }^{a}$ from receiving a maximum radioactivity dose in excess of 5 rem EDE from credible, postulated accidents that are analyzed in the FSAR

b. Protect the onsite worker from receiving an airborne concentration of nonradioactive hazardous material in excess of the applicable toxic chemical 1 imit in the ERPG No. 3 (ERPG-3) ${ }^{3}$

c. Protect the environment from damage to onsite and offsite rivers, lakes, or groundwater from dispersible radioactive materials or nonradioactive hazardous materials, where the EHSC ${ }^{1}$ number is $\geq 500,000$ but $<10^{6}$.

3 Safety $\mathrm{Class} 3$ (SC3) ensures that sufficient quality and environmental requirements are met to:

a. Protect the facility worker from receiving a maximum radioactivity dose in excess of an amount that is as low as reasonably achievable (ALARA) (see Section 12.2.1, Assuring That Occupational Radiation Exposures Are As Low As Practicable, ALAP)

b. Protect the facility worker from receiving an airborne concentration of nonradioactive hazardous material in excess of an amount that is ALARA

c. Protect the facility worker from industrial hazards, including fires

d. Protect the environment from unanticipated releases of radioactive materials or dispersible nonradioactive hazardous materials which exceed the threshold values that require reporting to Washington State or Federal agencies under applicable laws, regulations, DOE orders, permits, or agreements

An onsite worker has a normal workstation in the 400 Area but is located outside of the FFTF structures or outdoor control areas. NOTE: The FFTF FSAR does not specifically address providing protection for onsite workers because it was not a requirement at the time of construction. Protection for the offsite public combined with the ALAP program protection for the facility worker (As Low As Practicable, see Section 12.2.1) provides protection for the onsite worker.

${ }^{b} A$ facility worker has a normal workstation located within the FFTF structures or outdoor control areas, which require a keycard access. 
e. Provide monitoring of normal and unanticipated releases of radioactive materials or dispersible nonradioactive hazardous materials.

4. Nonsafety Class 4 includes all other items that meet the normal performance-oriented requirements but do not significantly affect personnel safety or health or environmental protection.

\subsubsection{REFERENCES}

1. Management Requirements and Procedures, WHC-CM-1-3, "Safety Classifications of Systems, Components and Structures," MRP 5.46, Rev. 4, Westinghouse Hanford Company, Richland, Washington, Aug. 28, 1991.

2. "FFTF MIDAS User's Guide," PS-98ABC-MIDAS/UGI, Rev. 6, Westinghouse Hanford Company, Richland, Washington, March 14, 1986.

3. Emergency Response Planning Guidelines, ERPG, American Industrial Hygiene Association, (AIHA), Akron, Ohio. (ERPGs are issued for individual hazardous chemicals as requirements are established.)

4. Environmental Compliance Manual, WHC-CM-7-5, "Standards for Radioactive Soil Contamination," Part K, Rev. 0, Westinghouse Hanford Company, Richland, Washington, October 1, 1988.

5. Job Control System, WHC-CM-8-8, "Process Description," Section JCS-1, Rev. 2, Westinghouse Hanford Company, Richland, Washington, July 3, 1991. 
Table 3.2-3. FSAR Systems and Phrases Equivalent to "Safety Class" (Typical page references)

Seismic Category I (FSAR, p. 3.2-1)

$\frac{\text { Safety Class" }}{\text { SCI }}$

Category I (FSAR, p. 7.2-11)

$\mathrm{SCl}$

SC I (Seismic Category I)

SCl

Seismic Category III/I (the specific attribute) SCl

Tornado Hardened (FSAR, p. 3.3-3) SC1

Plant Protection System (PPS) (FSAR, p. 7.1-4) SCl

Class IE Electrical (FSAR, p. 3.1-41) SCl

Containment Isolation System (CIS) (FSAR, p. 6.5-2) SC1

Control Room Habitability System (FSAR, p. 6.4-1) SC1

Decay Heat Removal System (FSAR, p. 7.2-25) SC1

Quality Classifications A, B, or C (FSAR, p. 3.2-11) SC1

Criticality Two-Contingency Features (FSAR, p. 20.3-1) SCl

Post-Accident Monitoring System (PAM) (FSAR, p. 7.2-5) SC1

Engineered Safety Features (ESF) (FSAR, p. 3.1-39) SC1

Design Features (FSAR, p. 17-228) $\quad$ SCl or 3

"Safety Related." (FSAR, p. 3.2-1) SCl or 3

"Important for Safety" (FSAR, p. 3.2-3) SC1 or 3

"Safety Equipment" (FSAR, p. 7.1-49) $\quad$ SCl or 3

"Critical" Instrument (FSAR, p. 7.1-11) SC1 or 3

Seismic Category III (FSAR, p. 3.2-4) SC3

Industrial Hazards $\quad$ SC3

"Some exceptions may exist.

NOTE 1: "Three levels of safety" are provided by the design in the FSAR (see Sections 1.1.2.1 and 6.1.4):

Level 1 is achieved by system design

Level 2 is achieved by system protective features

Level 3 is achieved by backup features that provide protection for analyzed hypothetical accidents (e.g., containment building).

These levels of safety are not related to SC3, SC2, and SC1.

NOTE 2: "Class 1, 2, or 3" refers to ASME B\&PV Code, Section III, Class 1, 2, or 3 (see p. 3.2-8) and are equivalent to Quality Classifications $A$, $B$, and $C$; they do not refer to Safety Classes directly. Most, but not ail, components built to these codes were analyzed for Seismic Category I requirements and hence are Safety Class 1. Refer to Figure 3.2-1, Red Line P\&ID Drawings, for details. 


\subsection{MISSILE PROTECTION}

\subsubsection{MISSILE BARRIERS AND LOADING}

Missile barriers are designed to protect structures and components necessary for safe shutdown from hazardous effects of internally or externally generated missiles. Such structures or parts thereof and their missile barriers are tabulated below.

STRUCTURE

Containment

Bldg. ( $\$ 405)$
MISSILE BARRIER

1" thick top shell

$13 / 8$ " thick

cylindrical shell
HTS E \& W BIdg. (\#491-E \& W)

Reactor Service B1dg. ( \#4717)
Conitrul Bldg.

(\#4703) \&

Auxiliary

Equipment

BIdg. $-E$

(\#4621-E)
2' 6" concrete

floor at El. 550'

2' $0^{\prime \prime}$ concrete wall

Sodium pump cell

hatches are

protected by 1/2"

thick steel

barrier.

$3^{\prime} 0^{\prime \prime}$ concrete

floor at El. 550',

$3 / 4$ " thick steel

barrier at

equipment hatch

and $1 / 2$ " thick

steel barrier at

Cask Loading

Station.

1' 0 " concrete floor at El. 550', and 3 ' 0 " concrete floor on top of Control Room and 2' 0 " concrete wall around the Control Room.
REMARKS

All components inside the Containment Vessel are protected. All PPS penetrations are hardened. External portions of electrical, heating and ventilation penetrations and equipment and personnel airlocks are not hardened.

All components below El. 550' and the secondary sodium pump and piping systems are protected.

All areas below El. 550' except stair openings are protected.

All components inside the Control Room or below El. 550' are protected. 


\begin{tabular}{|c|c|}
\hline STRUCTURE & MISSILE BARRIER \\
\hline HTS-S (\#491-S) & $\begin{array}{l}3^{\prime} 0^{\prime \prime} \text { concrete } \\
\text { floor at El. } 550^{\prime} \\
\text { and } 2 \text { ' O"-min. } \\
\text { concrete wall } \\
\text { below the } 550^{\prime} \\
\text { level. }\end{array}$ \\
\hline $\begin{array}{l}\text { Auxiliary } \\
\text { Equipment } \\
\text { Bldg. -W } \\
\text { (\$4621-W) }\end{array}$ & $\begin{array}{l}2^{\prime} 6^{\prime \prime} \text { concrete } \\
\text { floor at El. } 550^{\prime} \\
\text { and } 1 / 2^{\prime \prime}-\text { steel } \\
\text { barrier at } \\
\text { equipment hatch }\end{array}$ \\
\hline DHX-E (\#408A) & $\begin{array}{l}1 / 2^{n} \text {-thick steel } \\
\text { barrier }\end{array}$ \\
\hline
\end{tabular}

REMARKS

All components below El. 550' level, as well as sodium cells above, are protected.

All components below El. 550' are protected.

The missile barriers were designed to withstand the tornado wind load within the elastic range of the material and the impingement effects of the design missiles postulated in Section 3.5.3. The abovegrade tornado-hardened structures are illustrated in Figure 3.5-1.

\subsubsection{MISSILE SELECTION}

\subsubsection{External Missiles}

Falling objects generated from commerçal, industrial, or military activities near the plant site are not included as a design basis. All commercial and industrial activities on the Hanford Reservation are administratively controlled by the U.S. Department of Energy as to the nature and location of such activity. The nearest military installation is the Yakima Firing Range, $45 \mathrm{mi}$ west-northwest of the plant site. This is not a guided missile facility; therefore, no such missile hazard is postulated for the FFTF. Several airways pass near the FFTF; however, the probability of an aircraft accident affecting the FFTF is $<1 \times 10^{-7}$ per year and therefore isn't a design basis event. A detailed description of local air traffic is provided in Section 2.2.2.2.

One plant component was identified and analyzed as a potential external missile, the dump heat exchanger fan rotor. The fan is a double-width, double-inlet centrifugal fan with a maximum speed of 1,200 rpm. Design 
weighs about 90 pounds more, which has no significant effect on the seismic performance of the unit since the assembled weight is 4300 pounds.

Test response spectra exceeded required response spectra in all frequency bands except 1.4 to $1.8 \mathrm{~Hz}$. The test amplitude in this band was about 15 percent less than that required in the horizontal axis only. The zero period amplitude of the test response spectra was $1.8 \mathrm{G}$ horizontal and $1.1 \mathrm{G}$ vertical, which exceeds the required amplitude by a factor of 4.5 . The test response spectra was synthesized by combining pseudo-random inputs and sine beats.

A resonant frequency search at $0.33 \mathrm{G}$ was conducted from $1 \mathrm{~Hz}$ to $35 \mathrm{~Hz}$. No resonances were detected in the frequency range from $1 \mathrm{~Hz}$ to $2 \mathrm{~Hz}$.

The test was sufficiently conservative and the tested article was sufficiently prototypic to fully qualify the HTS main breaker for plant use. The tested unit functioned within design parameters and responded to close and trip commands during and after vibration tests as reported in Reference 12.

The HTS feeder breakers have been qualified by test in essential agreement with the procedure described in Section 3.9.2.1A. The test response spectra exceeded required response spectra and the breakers functioned within design parameters during and following vibration testing as reported in Reference 13. The breaker responded to close and trip commands during and after vibration tests.

Deviation from the described test procedure was limited to exposure time and motion analysis interval. The switchgear was exposed to the DBE test response spectra three times in each of the lateral-vertical and longitudinal-vertical directions for a total of 99 seconds and to one-half test response spectra levels for 99 seconds. The test motion was analyzed at $1 / 3$ octave intervals. The test is therefore only slightly less conservative than that described in Section 3.9.2.1A.

Solenoid valves and motor operators for containment isolation valves will be qualified by test in accordance with the procedure described in Paragraph 3.9.2.1B prior to installation in the plant. Isolation valves have been qualified by analysis as discussed in Section 3.7. 


\subsubsection{Seismic Qualification of Electrical Power System Equipment}

\subsection{Direct Current Power Equipment}

Storage batteries have been qualified by test in essential agreement with the procedure described in Section 3.9.2.1A. Test response spectra exceeded required response spectra and the batteries met functional design parameters during and after vibration testing, as reported in Reference 14.

The battery cells were mounted in a rack in groups of three. Although the racks used were similar to those in the plant, there was no attempt to qualify the racks in this manner.

The tests differed from the described procedure in test duration and number of DBE tests. A low-level (approximately $0.2 \mathrm{~g}$ ) single-axis sine sweep was performed in each of the three orthogonal axes. The frequency range of the sine sweep was from 0.5 to 40 to $0.5 \mathrm{~Hz}$ at a sweep rate of one-half octave per minute. The specimens were then subjected to 30-s-duration biaxial, multifrequency, random motion which was amplitude-controlled in one-third octave bandwidths spaced one-third octave apart over the frequency range of 1 to $40 \mathrm{~Hz}$. Three simultaneous, but independent random signals were used as the excitation to produce phase-incoherent motions in the vertical and two horizontal axes. The amplitude of each one-third octave bandwidth was independently adjusted in each axis until the test response spectra enveloped the required response spectra. The resulting table motion was analyzed by a response spectrum analyzer at $2 \%$ damping, and plotted at one-sixth octave intervals over the frequency range of 1 to $200 \mathrm{~Hz}$.

The racks to support the batteries were qualified through prediction of equipment performance by mathematical analysis. This is one of the two methods authorized by Section 3.9. This analysis was completed by Arora and Associates subcontracted to GNB Industrial Battery Co. and is reported in Reference 32.

Direct current distribution panels have been qualified by test in essential agreement with the procedure described in Section 3.9.2.1A. Test response 
spectra exceeded required response spectra and the panels functioned with in design parameters during and after vibration testing, as reported in Reference 15. The test differed from the described procedure only in exposure duration and narrowband test response spectra low amplitude.

The test panels were exposed to three DBE simulations in each of the lateralvertical and longitudinal-vertical directions for a total duration of $360 \mathrm{~s}$.

The test table was not able to provide required horizontal motion between 1.25 and $1.6 \mathrm{~Hz}$ because of displacement limitations. A resonance search was therefore performed in both horizontal axes over the range of 1 to $5 \mathrm{~Hz}$. Five response accelerometers were mounted in the panel to measure panel response. No resonances were observed.

The tested distribution panel is a plant unit containing devices used in other, smaller distribution panels that require qualification. The tests performed on the larger panel have been shown to be fully applicable to other smaller panels by analysis. Thịs analysis provides calculated resonant 
14. Seismic Simulation Test Program on Six Naturally Aged NCX1680 and Three Naturally Aged MCX510 Battery Cells, Wyle Laboratories for Gould, Incorporated, Report 48725-1, April 17, 1987.

15. Seismic Test Report, Wyle Laboratories for Delta Switchboard, Report 53782, August 5, 1974.

16. Analytical Justification for Using Two Panels for Seismic Qualification on Purchase Orders E-15 and E-47, Delta Switchboard (undated).

17. Seismic Vibration Test on Motor Generator Set Part No. 73-422-2 for Holt Brothers, Wyle Laboratories for Holt Brothers, Report 53789, January 28, 1975.

18. Stress Report For FFTF In Accordance With ASME BPVC Code 3 Subsection N.E., Richland, Washington. Amphenol Western Connector Division, 123-2036H, March 10, 1975.

19. Design Qualification Testing Report of Prototype Assemblies for the Fast Flux Test Facility, Richland, Washington. Amphenol Western Connector Division, 123-2037, September 9, 1974.

20. Seismic Analysis of Control Room Console, Prepared for Reliance Custom Controls by Control Data Corporation, December 1973.

21. Sefsmic Simulation Test Program on Seven Electrical Components, Wyle Laboratories for Reliance Electric, Report 42695-1, March 21, 1974.

22. Seismic Simulation Test Program on Three Cabinet Racks and Console Simulator Group DHX, Wyle Laboratories for Honeywe11, Inc., Report 42831-2, January 20, 1975.

23. Seismic Test Report (C137B \& E), Honeywell, Inc., February 27, 1975. Includes Reference 21 above. 
24. Seismic Vibration Tests of DHX and Preheat Panels FFIF, Analytical Engineering Associates, Inc., for Honeywe11, Inc., Report 74013-T1, December 2, 1974.

25. Seismic Test of Two Power Positioners and a Solenoid Valve, Westinghouse CID, for Struthers Wells, Report EL: 516, July 1975.

26. Seismic Verification Report for Qualification Testing Conducted from 12-6-74 to 12-12-74 - Cabinet C126A. Honeywell, Inc., February 28, 1975.

27. Seismic Verification Report for Qualification Testing Conducted April 17, 1974 to April 19, 1974 on 204C Cabinet, Report 42702-1, Honeywell, Inc., May 24, 1974.

28. Seismic Vibration Test, Seismic Monitoring System, HWS-1255, P.0. 8776-I-056, Teledyne Geotech, March 30, 1975.

29. Primary and Secondary Transformer Structural Analysis, Royal Industries Report 128X276, January 29, 1975.

30. Seismic Simulation Test Program on Two Cabinets (Nos. 127 and 890), Wyle Laboratories, Inc., Report Number 43154-1, dated January 15, 1976, Huntsville, Alabama.

31. Seismic Qualification of Agastat Model E7014AD and E7022AA Relays for FFTF Usage, Westinghouse Hanford Company, M. R. Lindquist, WHC-SD-FF-SA-008, dated March 13, 1991, Richland, Washington.

32. Seismic Calculations and Packaging Details, Arora and Associates, P. C. Consulting Engineers, for GNB Industrial Battery Co., Job \#1034-21, November 12, 1987. 
Before nuclear operation, the primary temperature was raised to $800{ }^{\circ} \mathrm{F}$ utilizing pump power, 1.e., non-nuclear heat. When the temperature was at $800^{\circ} \mathrm{F}$, a periscope investigation of the HTS and valve cells was made to ensure that the pipe hanger displacements remained within acceptable ranges during that period of operation.

An inspection of numbers 1 and 2 primary pump shield plug/support cylinder (SP/SC) assemblies will be performed before sodium fill to ensure that the routine precautions to avoid a hostile environment in containment have been exercised. The need for these inspections results from the intergranular attack problem (IGA) that occurred during the manufacture of the SP/SC for the primary pumps in Loops 1 and 2. An evaluation of the IGA problem was performed and corrective actions were implemented. ${ }^{(30)}$ Inspections will be performed again $1 \mathrm{yr}$ after FFTF plant operation to confirm that the containment environment has not initiated or propagated IGA. These inspections will be compared to baseline inspections made before shipment of the pumps to the site. Inspections beyond the 1-yr period are not required unless the inspection at 1 yr has indicated potential problems.

Accelerometers have been provided at several locations on the primary and secondary pumps: (a) near the pump discharge nozzle, (b) on the drive motor frame, and (c) on the seal/bearing housing. Vibrations will be.: recorded during initial startup and for all speed changes, starts, and coastdowns until the pump has operated at full speed for at least onehalf hour. During normal operation, vibrations will be measured regularly to monitor the pump operation with either accelerometers or equivalent measuring equipment.

A summary of the surveillance and in-service inspection to be performed is shown in Table 5B.4-1.

\section{B.4.1.2.4 Sodium Leak Detection}

Although the probability of a sodium leak is small, leak detection is provided for primary and secondary sodium-containing equipment to provide early warning 
in the event of a sodium leak. Early detection allows prompt corrective action, which can minimize the adverse effects, such as corrosion of the boundary material or a sodium fire, that might result from a sodium leak.

The primary functions of the leak detection system are:

1. To notify the operator of the presence of a sodium leak at the earliest possible time

2. To minimize the time required to locate the position of the leak and thereby reduce the potential down time.

The purpose of the primary HTS leak detection system is, therefore, to provide early detection of small leaks and thus minimize the potential for large leaks.

The primary HTS leak detection systems include the continuity type (spark plug) leak detectors and the aerosol leak detection systems. These are supplemented by the Nitrogen Atmosphere Sampling and Analysis System (System 82). The continuity leak detectors are located in the Reactor Guard Vessel, in each HTS guard vessel, underneath the isolation valves and check valve, and along primary piping runs. These leak detectors will respond when sodium shorts out the contacts and will actuate an alarm. Thermocouples between the freeze seals and the backup seal packing on the primary and DHX isolation valves will detect a failed freeze seal by a temperature increase. The aerosol leak detection system monitors the atmosphere within the Reactor Guard Vessel and the reactor guard pipes by means of a sodium ionization detector (SID) and replaceable filters. This system continuously samples the nitrogen gas in the Reactor Guard Vessel to check for the presence of any sodium. Aerosol monitors also sample the Reactor Cavity and HTS cell atmospheres. The Nitrogen Atmosphere Sampling and Analysis System can detect leaks in the Reactor Cavity area and in the inerted HTS cells and pipeways by periodically checking for decreases in oxygen and moisture and increases in radiation that would result from a leak.

In the secondary HTS system, ionization-type smoke detectors are provided in air atmospheres to respond to the smoke of a sodium fire resulting from a 
leak. For the DHX modules, a low secondary expansion tank level alarm will provide an indication of a leak. Each shutdown, the DHX internal air is sampled, filtered, and analyzed for traces of sodium aerosol.

Any actuation of a leak detection system will result in local alarms in the HTS Service Buildings or in-containment. Common alarms are provided in the control room, to alarm leak detection signals for specific areas.

Table 5B.4-2 shows the leak detection systems and their respective sensitivities, response times, and threshold detection limits. Appendix $G$ of SDD-51 (Continued on page 5B.4-21) 
4. Electrical Requirements:

The radiation monitoring and toxic materials monitoring equipment shall be designed to operate from the following power source: $120 \mathrm{~V}$ ac $\pm 10 \%, 60 \pm 3 \mathrm{~Hz}$. Channels $A$ and $B$ of the CIS monitors, the gamma-sensitive monitor of CR atmosphere, the containment postaccident monitors and the CAPS exhaust PPS monitors shall be supplied from the 2TO buses. Channel C of the PPS monitors shall receive power from Emergency Power Buses. All other radiation monitors shall receive power from Emergency Power Buses.

5. Design Life:

A target 1 ife of 20 years shall be used as a basis for the design. Components for which a predicted 20-year 1 ife expectancy cannot reasonably be assured shall be installed to permit replacement.

6. HCDA

The containment high-range post-accident monitors and the control Room Habitability monitors for sodium and radioactivity shall be designed to perform their functions in the postulated environment following an HCOA.

\subsection{Design Margins for Hypothetical Accidents}

Design margins provide equipment capable of monitoring the radiation levels postulated to emanate from the containment dome above the operating floor that would result from a major accident up to and including an HCDA.

\subsection{Design Codes}

The codes and NE standards used in developing System 96 design are References 5 through 11.

\subsubsection{Design Description}

A. Summary Description:

System 96 is divided into four subsystems. The Area Monitoring Subsystem serves to warn operating personnel of excessive radiation and includes Post-Accident Monitors of containment and gamma monitors of CR atmosphere. The Process Monitoring Subsystem regulates radioactive 
processes and warns of malfunctions. The Air Monitoring Subsystem indicates the presence of radioactivity, sodium, and chlorine in the control room H\&V supply ducts. High levels are alarmed and the first two initiate control room isolation. The CIS monitors the head compartment exhaust and containment exhaust and acts by interfacing with the PPS to effect containment.

\section{B. Area Monitoring Subsystem:}

Area monitoring consists of fixed and portable radiation monitoring sensors, readouts, alarms, and air samplers whose primary purpose is to provide protection for plant employees by monitoring the plant work areas and ventilating system. These instruments alarm when local radiation is detected. Area monitors are provided in approximately 38 plant work areas to continuously monitor the radiation status of the plant and provide indication and alarms in the monitored areas and in the control room when limits are exceeded. Four of the monitors are provided in cells containing secondary HTS piping. These monitors warn of possible release of radioactive sodium to the secondary system and provide protection for personnel in the vicinity of secondary piping.

A group of three of these monitors in containment and three in the RSB are each connected in two-out-of-three logic which automatically initiates an evacuation alarm when predetermined limits are exceeded. These six monitors comprise the high-gamma evacuation subsystem for the operating floors (550-ft level) of containment and the RSB.

Redundant high-level post-accident monitors (PAM) function by sensing the radiation levels from the containment dome above the operating floor that could result from a major radiological accident up to and including an HCDA. The PAMs immediately outside of containment fulfill this function. 
monitor the status of the air contamination when the life support system is in use. To provide assurance that the system is operable when needed, it is tested on a periodic basis. The air is sampled from the duct which transports air to the control room. This duct is a portion of the recirculation system that will be in use during all modes of operation of the H\&V system.

The continuous monitors provide indication and annunciation in the control room and are recorded by the DDH \& DS.

The portable CAMs previously described can be attached to the monitored ducts and can temporarily be substituted for the fixed continuous monitors during maintenance periods.

The control room inlet air is monitored for gaseous radioactivity and sodium. High levels of radioactivity or sodium will isolate the control room H\&V.

\section{E. CIS Radiation Monitoring Subsystem:}

The main H\&V duct which vents all of containment and the H\&V duct which vents the head compartment to the main H\&V duct are each monitored with a set of three redundant gamma detectors to initiate closure of the Containment Building H\&V valves if a preset limit is exceeded, and to initiate Principal Containment when a higher preset limit is exceeded. These six monitoring channels are part of the PPS and as such meet the. requirements for PPS systems as defined in SDD-99.

These two sets of detectors are of the same design, one set being located adjacent to the main H\&V duct with about six seconds of transit time (at normal flow rate) before the exhaust air exits containment, and the other set being located adjacent to the head compartment duct prior to its junction with the main containment exhaust duct.

The sensors respond to direct radiation releases in containment up to an HCDA release. The sensors can also detect radioactivity caused by the transport of radioactive gases or particulates to the sensor location adjacent to the ducts. In either case, the radioactive gas or entrained particulates are detected with sufficient lead time so that the H\&V valves are closed before the active material can leave containment. The Radiation Monitoring System provides signals to the PPS-CIS with sufficient sensitivity that the limits stated in Table 7.1-2 will not be exceeded. 
F. Air Monitoring During Containment Isolation:

A provision for monitoring the airborne radioactivity of the atmosphere inside the containment vessel during containment isolation is made by piping penetrations at the equipment air lock. To perform this operation, portable monitors can be connected to the piping penetrations.

\subsubsection{Design Verification and Acceptance}

\subsection{Design Analysis}

A. The following analyses were performed in order to prepare the specification for the equipment:

1. Sensitivity--All portions of the system have been analyzed to verify that the minimum sensitivity requirements can be met

2. Location--Locations have been chosen so as to optimize safety.

3. System.. 96 has been analyzed to verify that the CIS design basis has been met.

B. Additional sensitivity and reliability analyses are required of the vendor to ensure that the equipment specifications are met.

\subsection{Performance Tests}

The procurement specification of the Radiation Monitoring System requires the vendor to perform verification tests. These include the following:

1. Channel Accuracy--Calibrated radioactive sources will be used to verify that required accuracy specifications are met

2. Sensitivity--Mintmum radiation levels above the expected background radiation will be used to verity sensitivity requirements.

3. Alarm Trip Verification--Trip accuracy will be verified with external sources

4. Stability--Equipment drift will be verified to be within specification over at least a 24-hour period 
Control of argon supply pressure to reactor seals is accomplished with a conventional pressure feedback control system. Inlet line pressure is measured and pressurization valve position automatically adjusted to maintain a constant pressure.

Primary HTS pump argon seal pressure and lube $0 i 1$ argon pressure are controlled in a manner similar to that described above. Cover gas pressure is controlled by the reactor cover gas control system because the reactor cover space and each pump cover space are interconnected by gas equalization lines. Primary pump cover gas pressure is indicated in the control room.

Cover gas pressure of secondary HTS pumps and expansion tanks is controlled in the same manner as reactor cover gas pressure except that inlet flow limiting is not employed.

Cover gas pressure control of the CLS surge tanks, the IDS, IEM Cell, and the Auxiliary Liquid Metal System tanks also employ a feed and bleed system without inlet flow limiting.

Control of Secondary HTS, IDS, CLS, and Auxiliary Liquid Metal System argon supply is provided at local control stations.

Indication of liquid argon level in argon storage dewars is provided in the control room. Argon distribution header pressures are indicated in the control room. Conventional instruments are provided for these measurements.

\subsection{Nitrogen Supply and Pressurization Instrumentation}

Instrumentation for nitrogen supply and pressurization is designed to monitor and control nitrogen service supply to inert gas cells. Principal features of this system are as follows:

1. Control and monitor cell gas pressure and oxygen content

2. Monitor cell gas humidity content

3. Record cell gas radiation (signals provided by the Radiation Monitoring System, SDD-96)

4. Monitor nitrogen instrument gas header pressure 
5. Control and monitor nitrogen supply pressure to the Control Rod Drive Mechanisms (CRDM) and Low Level flux Monitor (LLFM).

6. Monitor liquid nitrogen storage inventory and nitrogen distribution headers.

Cell gas pressure and oxygen content are controlled by three different methods, depending on $p$ lant location.

1. The reactor cavity operates at a slight positive pressure which is maintained by a constant nitrogen purge. A mass flowmeter controller in the reactor cavity nitrogen feed line regulates the nitrogen pressure control valve which maintains the prescribed flow rate. The nitrogen supply is premixed with dry instrument alr to maintain a specified oxygen content. The oxygen concentration is controlled by an oxygen monitor and controller downstream of the nitrogen/air mixing valve.

2. Inerted cells in-containment other than the reactor cavity operate at a slight positive pressure. Like the reactor cavity, the nitrogen feed gas is pre-mixed with air to a prescribed oxygen level. Provision is made for negative pressure operation of any cell in the event of a small radioactive argon leak.

3. The ex-containment inerted cells in HTS-South operate at a slight negative pressure.

Cell gas pressure control for Groups 2 and 3, above, is accomplished by use of a feed and bleed control scheme similar to that used for reactor cover gas pressure control. Cell differential pressure is sensed, with respect to reactor containment pressure or amblent atmospheric pressure, by a conventional differential pressure transmitter. The measured pressure provides input to a proportional controller which regulates nitrogen feed and bleed valve positions. A sufficiently wide control deadband is provided to prevent both feed and bleed valves from being open at the same time. 
package unit, seismically qualified to Category I per Ref. 37, completely self-sufficient for operation, requiring only interfaces for incoming fuel, and electrical circuits for control and power output. The design was verified by factory testing at various power output levels including full-rated power. These tests established calibration of turbine control, protection devices, and of the excitation control of the generator.

Subsequent to the rated power testing, the unit was mounted on a test stand at the Earthquake Simulator Laboratory of the University of California, Berkeley, and subjected to seismic testing consistent with the requirements of Ref. 37 for Seismic Category I equipment. For the test, all on-set connections were made up and all fluid systems were filled. Following the test, the unit was returned to the test area at the manufacturing $p l$ ant for inspection and load testing. No damage or distress as a result of the seismic test were detected. Repeat of the load tests demonstrated satisfactory performance.

B. Acceptance Testing -- Following installation, startup and acceptance tests were performed to verify performance capabilities and operational readiness. Initially the test program verified operation of the turbine support equipment, including the fuel oil transfer system, the centrifuge and control panels. Because the turbine/generator provides power for its own auxiliaries and has storage batteries for cranking, it is not dependent on the availability of external power in order to run.

Starting and load tests demonstrated the equipment's ability to provide stable power at all levels from no load to $110 \%$ load. A 24-hour, fullload test, followed immediately by a 2-hour, 10\%-overload test were completed successfully without incident, verifying that turbine gas temperatures, fuel supply and lube oil temperatures stabilized within the 1 imits recognized for normal operation. The generator output was paralleled with offsite power to provide load. Excitation and power 
factor regulators were observed to control generator voltage accurately for varying load conditions. The turbine speed control was adequately adjustable to facilitate paralleling without difficulty. At the conclusion of the 2-h, 110\%-load test, the load was adjusted back to the full-load level and the generator circuit breaker tripped to verify the ability of the speed governor and voltage regulator to limit the transient swings of frequency and voltage to levels that did not cause tripping or shutdown.

\subsubsection{Feature Tests for $125 \mathrm{~V}$ DC Systems}

\subsection{Design Testing}

Three cells mounted in a shortened but typical battery rack were tested to demonstrate their qualification to the Seismic Category I level. Similar tests were done for the $D C$ distribution panels to qualify them. Ampere-hour capacity tests for both batteries were performed at the manufacturer's plant.

\subsection{Acceptance Testing}

After Instaliation, each battery was given a repeat discharge test to verify the acceptability of the battery connections and the as-installed ampere-hour capacity. Following this discharge, each charger was tested to verify its ampere rating and its general performance in restoring the battery capacity. Other tests were made for the proper operation of the meters, the setting of the undervoltage relays, and the sensitivity of the ground detectors. Distribution cable was checked for proper insulation, and breakers were tested for operability. All acceptance test results met the requirements.

For further acceptance testing information, see FSAR Chapter 14. 


\subsubsection{ZTO M-G Set Testing}

A series of qualification tests were conducted by the $M-G$ set manufacturer to determine the adequacy of the equipment to meet the requirements. Seismic testing is described in Section 3.9.2. A listing of the operational tests performed by the manufacturer follows:
a. Transfer Time
b. Steady-State Load
c. Transient Load Change
d. DC Motor Overspeed
e. Generator Output Overvoltage
f. Harmonic Content
g. Voltage Modulation
h. Assembled Machinery Balance
i. Instrumentation Check.

The following results were obtained. Performance tests were made at the nameplate rating of the generator ( $15 \mathrm{~kW}, 120 \mathrm{~V}, 1$ phase, $0.8 \mathrm{pf})$.

A. Transfer Time -- The unit was operated under AC motor drive and in the automatic control position. The $A C$ voltage was then lowered to 414 V AC. The unit transferred to $D C$ drive within the 0.4-s time 1 imit and maintained the voltage and frequency within the $120 \pm 12-\mathrm{V}$ limit and $60 \pm 2.5-\mathrm{Hz}$ limit and within the 0.5 and $5.0-\mathrm{s}$ respective recovery times. The $A C$ input voltage was returned to $460 V A C$ and the unit transferred back to $A C$ motor drive. The $A C$ input frequency was then lowered to $59 \mathrm{~Hz}$. The unit transferred to $D C$ motor drive within the aforementioned transient limits. The $A C$ input frequency was returned to $60 \mathrm{~Hz}$ and the unit returned to $A C$ motor drive. A manual transfer from $A C$ to $D C$ drive and back to $A C$ drive was performed to check out the manual circuitry. 
B. Steady-State Load - The unit was operated under $A C$ and then $D C$ drive with a 15-kW steady-state load while the generator output was observed. The output remained within the stability limits of $120 \mathrm{~V} \pm 1 \%$ and $60 \pm 1 \mathrm{~Hz}$.

C. Transient Load Change -- The unit was operated under $A C$ and then $D C$ drive while a $100 \%$ step load change was placed on the generator. The unit maintained the voltage within the $120 \mathrm{~V} \pm 10 \%$ band with recovery to within the $1 \%$ band in $<0.5 \mathrm{~s}$, and maintained the frequency within the $60 \pm 2.5-\mathrm{Hz}$ band with recovery to within the $2 \%$ band in under $0.4 \mathrm{~s}$.

D. DC Motor Overspeed -- The DC motor speed was increased by raising the DC voltage to confirm the overspeed relay trip point of $2,000 \mathrm{rpm}$.

E. Generator Output Overvoltage -- The generator output was increased to confirm the overvoltage trip point of $156 \mathrm{~V} \mathrm{AC.}$

F. Harmonic Content -- The harmonic content of the output was measured and found to be within the prescribed limits of $5 \% \mathrm{rms}$ total and $4 \% \mathrm{rms}$ for any single harmonic.

G. Voltage Modulation -- The voltage modulation in the generator output was observed to be less than the $0.5 \%$ specified limit. 
Table 8.2-2 (cont.)

Idenification of critical control and instrumentation loads

DC AH

equivalent (see notes)

\begin{tabular}{|l|l|}
\hline 3. Metering - Voltmeters for $D C$ and inverter output. & Monitoring for battery and inverters \\
4. Battery leakage resistance & Allowance for undetected battery drains
\end{tabular}

Notes: "Each battery is rated $860 \mathrm{AH}$ at $77^{\circ} \mathrm{F}$ and 8-h discharge rate to $1.75 \mathrm{~V}$ per cell or $105 \mathrm{~V}$ for the battery.

bAll loads are adjusted for discharge rate and battery temperature of $50^{\circ} \mathrm{F}$. The AH equivalent represents the $8-h$ rate at $i 7^{\circ} \mathrm{F}$. Inverter efficiency assumed to be 0.60 . 
Table 8.2-3

PROTOTYPE PENETRATION MODULE ACCEPTANCE TESTS

TEST DESCRIPTION

1. Visual inspection

2. Leak Integrity

3. Voltage Withstand (Hi-Pot) (pin-to-pin and pin-to-ground)

4. Insulation Resistance (pin-to-pin and pinto-ground)
MODULE TYPE

A11

A11

L.V. Control and Med. Volt Power (600 V rated)

A11
ACCEPTANCE TEST LEVEL

No voids, pits, etc., on seal surface

Leak rate less than $1 \times 10^{-8} \mathrm{cc} / \mathrm{sec}$ as measured with VEECO Mass Spectrometer

2640 Vac for $2 \mathrm{sec}$

$1 \times 10^{8}$ ohms at $500 \mathrm{Vdc}$ 


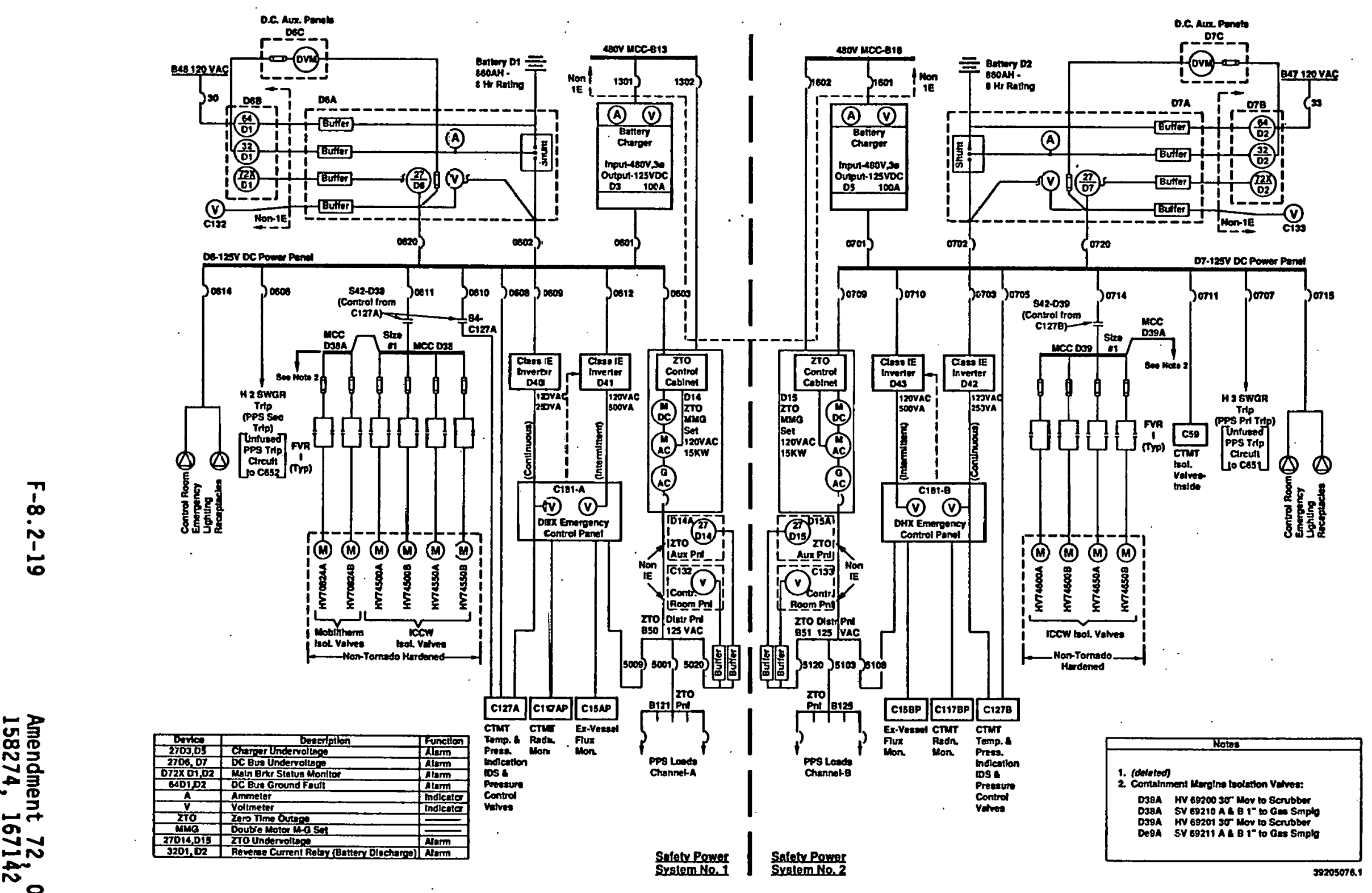

FIGURE 8.2-5a. Single Line Diagran (1E) 125 VDC System. 

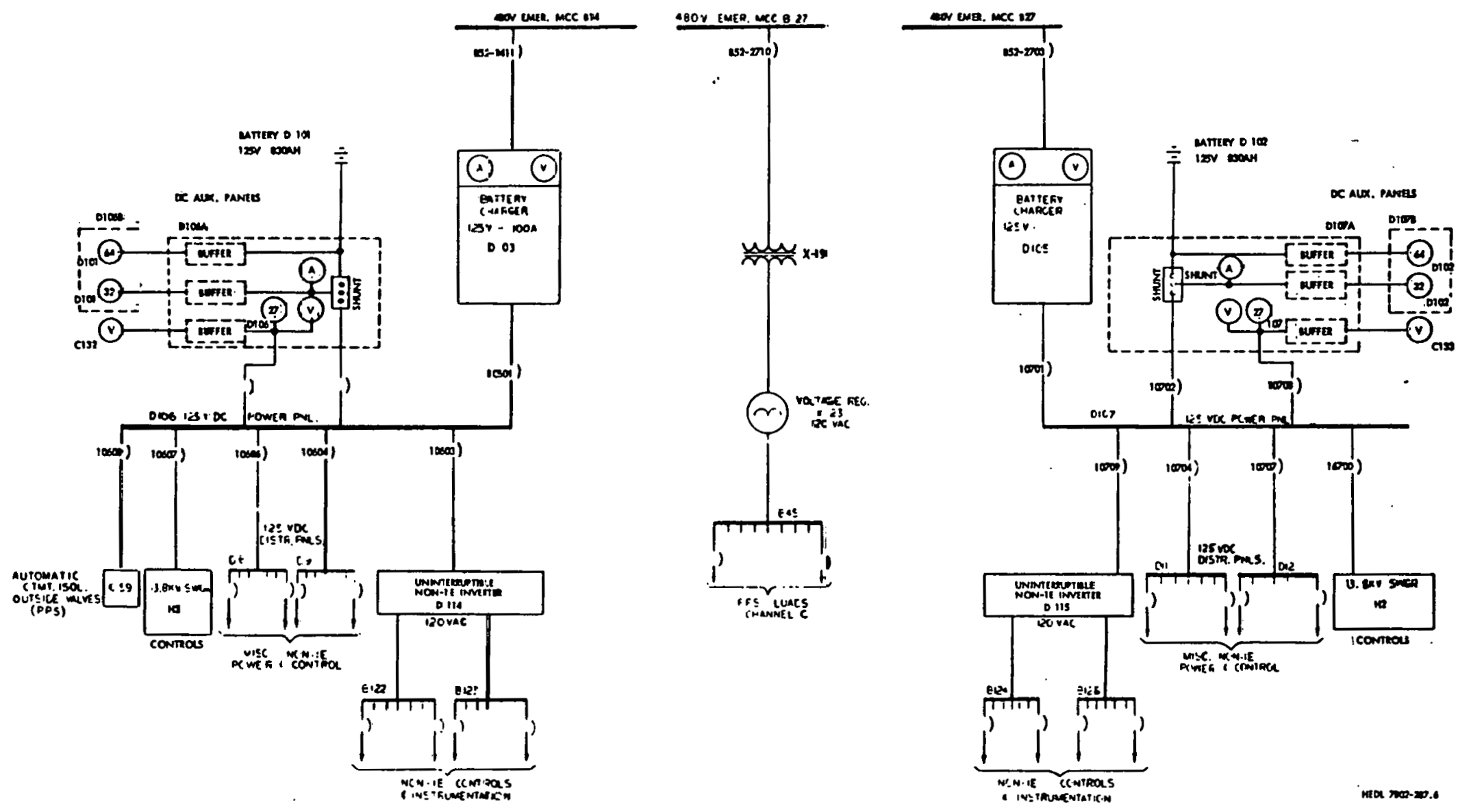

FIGURE 8.2-5b. Emergency Power System (Non-1E) Single Line. 


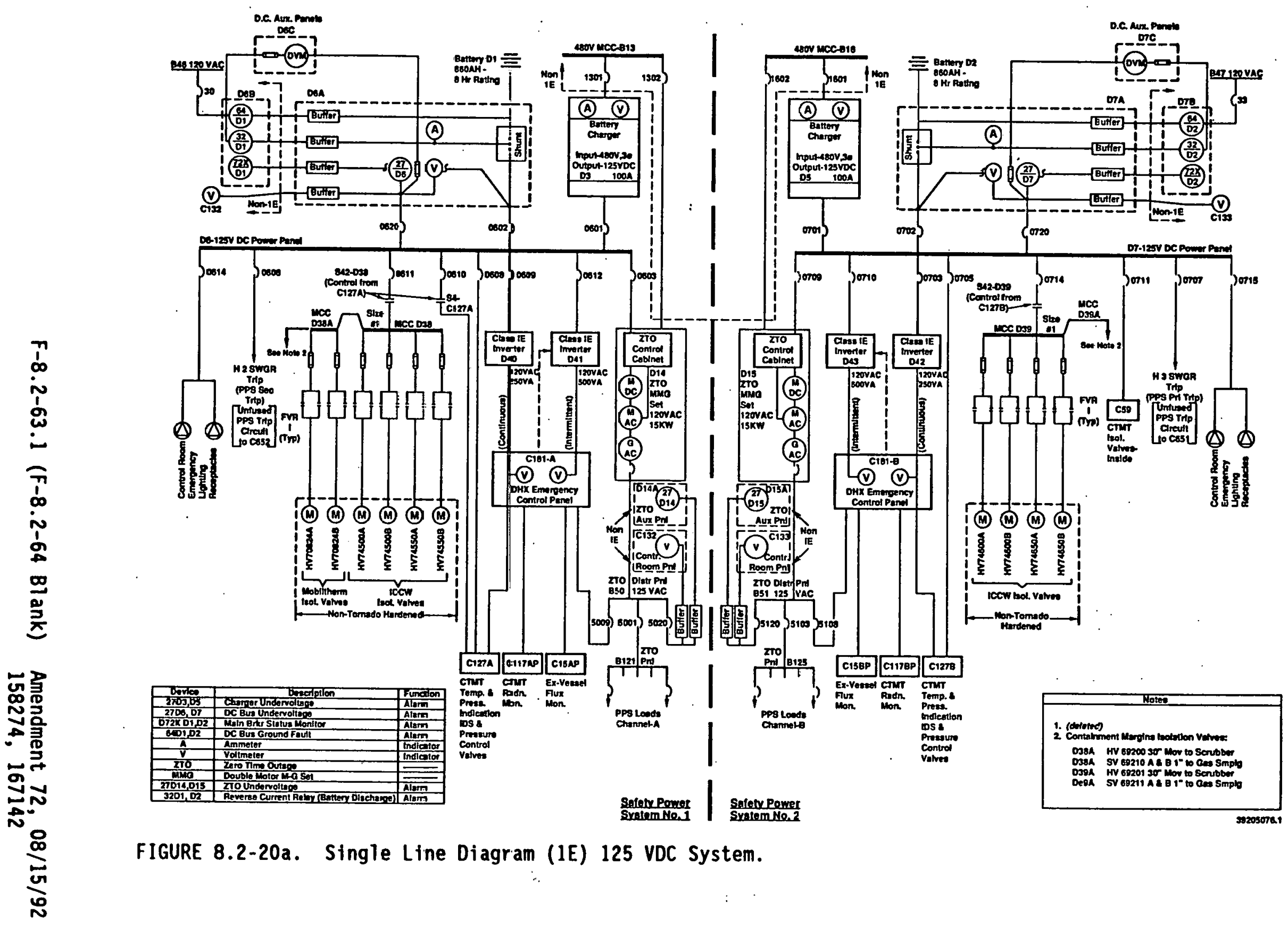


Reduction from supply pressure to the low pressure service level is accomplished through dual pneumatically actuated, fully isolable, pressure control valves; one valve group is on-line, the other is redundant. This arrangement allows continued low pressure service during maintenance and power outages, and the redundancy can compensate for certain control malfunctions. An additional reduction to a lower pressure provides the pressure control for the inerted area. An automatically operated, differential pressure actuated, fully isolable, feed/bleed pressure control valve arrangement is employed. A remotely operable purge bypass valve is provided on the supply side with a manual bypass provided on the discharge side.

The in-containment low pressure nitrogen ( $1.2 \%$ oxygen) supply flow is automatically regulated to insure that off normal demands in the inerted areas do not overload the Cell Atmosphere Processing System. Reduction from supply pressure to high pressure service is accomplished by an automatically operated set of feed/bleed pressure control valves. Each control valve is fully isolable and has a manual bypass. Supply pressure reductions, such as instrument nitrogen regulation, are accomplished by single fully isolable, self-contained pressure regulators. A manual bypass is provided. Cell purge service is provided through branch lines with single block valves.

The design pressure for the piping at each stage of the distribution system is selected so that a single control valve failure or operator error will not induce stress levels in the piping of components in excess of that allowed by the appropriate design code.

Self-sensing automatic containment isolation valves are provided on the high pressure distribution piping entering containment. This allows for flow into containment as long as the line pressure is maintained. A reduction from the normal pressure will cause the isolation valves to close, thus insuring the containment vessel's structural integrity of at least 10 psig through the containment penetrations. Low pressure lines which do not have self-sensing containment isolation valves close automatically upon Containment Isolation System (CIS) actuation. The nitrogen distribution system containment penetrations are automatically closed during a principle containment isolation. 
The nitrogen distribution piping is designed, constructed, and tested in accordance with the provisions of ANSI B31.1 except for the containment penetrations which are designed to the provisions of the ASME Code Section III per HWS-2353, Piping Design Criteria for System 82. Except for the containment penetrations, no special requirements apply to the nitrogen distribution system because the piping neither serves as a necessary boundary on serviced equipment nor is required to maintain the reactor in a safe shutdown condition.

The nitrogen distribution network is designed to perform all the required distribution and pressure control functions. Continuous pressure control is ensured by inclusion of redundant automatic control elements. Single-element control functions can be continued by manual control. The system is protected against the effects of overpressure by the parameter limitations inherent in the system's design and operation.

\section{Purity Control}

The Nitrogen System, which includes the supply and distribution networks, performs the function of monitoring and maintaining the purity of the nitrogen-inerted areas. Also, it monitors the radioactivity levels in certain air atmosphere areas. The monitoring function is accomplished by five groups of gas monitoring modules. Four groups monitor nitrogen atmospheres for oxygen, water vapor content, and radioactivity level. The fifth group monitors air atmospheres, in HTS Service Building South, for radioactivity levels.

Monitoring is automatic, except in the case of moisture analysis, which is initiated manually. Each module group acts to sequentially sample the atmosphere of each cell connected to its sample collection header. A total of 10 sample points ( 8 maximum in use and 2 minimum spares) are available for each module group. Sample duration is about $10 \mathrm{~min}$. Thus, each used sample point is sampled at least once every $80 \mathrm{~min}$.

Sample taps, provided in the System 25 ducting, allow a grab sample analysis as backup to the automatic sampling function. 


\subsection{REACTOR REFUELING SYSTEM}

Page

11.1.1 DESIGN BASES

11.1-1

11.1 .1 DESIGN BASES

11.1.1.1 Functional and Performance Requirements

11.1.1.2 Design Parameters

11.1.1.3 Service and Transient Conditions

11.1.1.4 Design Safety Margins for Hypothetical Events

11.1.1.5 Documentary Criteria

11.1.1.6 Instrumentation and Control Requirements

11.1-1

11.1-1

$11.1-2$

$11.1-4$

11.1-6

$11.1-6$

11.1-8

11.1 .2 DESIGN DESCRIPTION

11.1-8

11.1.2.1 Core Component Handling

11.1-11

11.1.2.1.1 Initial Core Component Handling

11.1.2.1.2 Cycle One Core Component Handling

11.1.2.1.3 Core Characterizer Component Handling

11.1-12

$11.1-12.2$

$11.1-12.4$

11.1.2.2 Test Assembly Handling

$11.1-12.5$
11.1.2.2.1 Initial Test Assembly Handling

$11.1-15$

11.1 .3 DESIGN VERIFICATION AND ACCEPTANCE

$11.1-15.2$

11.1.3.1 Analysis

$11.1-15.2$
11.1.3.1.1 Thermal
11.1.3.1.2 Radiation and Containment
11.1.3.1.3 Mechanical
11.1 .3 .1 .4 Seismic
11.1.3.1.5 Failure Analysis

$11.1-15.2$

$11.1-19$

$11.1-21$

$11.1-21$

$11.1-23$

11.1.3.2 System and Feature Tests

11.1-24

11.1.3.2.1 Emissivity Tests

11.1.3.2.2 Heat Removal Tests

11.1-24

11.1.3.2.3 Inflatable Seal Tests

$11.1-25$

11.1.3.2.4 Acceptance Tests

11. $1-25$

11.1-25 


\subsubsection{EVALUATION}

Page

11.1.4.1 System Design Evaluation

$11.1-26$

11. 1-26

11.1.4.1.1 Protection of Nuclear Properties

11.1.4.1.2 Accountability of

$11.1-26$

Serialized Assemblies

11.1.4.1.3 Provisions for Safe

Functional Operation

11.1.4.1.4 Packaging of Radioactive Material

11.1.4.1.5 Examination and Reassembly

11. 1-27

$11.1-28$

$11.1-34$

of Special Test Assemblies

11.1.4.1.6 Introduction of Foreign

Objects

11.1.4.1.7 Leakage Provisions

11.1.4.1.8 Shlelding Provisions

11.1.4.1.9 Criticality of Fuel

Assemblies

$11.1-35.1$

$11.1-35.1$

$11.1-36$

$11.1-37$

11.1-38.1

11.1.4.1.9.1 Criticality

Experiments

11.1.4.1.9.2 Criticality

Analyses

11.1.4.1.9.3 Criticality

Safety of

Reactor

Refueling

System

$11.1-40$

11.1.4.1.10 Error Avoidance in Fuel Handling Operations

$11.1-46$

$11.1-47$

11.1.4.2 System Protective Features Evaluations

$11.1-47$

11.1.4.2.1 Loss of Off-Site Power

$11.1-48$

11.1.4.2.2 Emergency Cooling

$11.1-48$

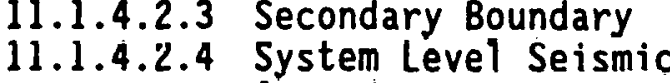

Considerations

$11.1-49$

11.1.1.2.6 Loss of Emergency Püwer

$11.1-50$

11.1.5 REFERENCES

11.1-57 
position. There are three IVSM locations within the RV, one in each sector between the core barrel and the RV. Each module contains storage locations for up to 19 core components. When decay heat is less than $10 \mathrm{~kW}$ per assembly, fuel can be moved directly from the core to a transfer location by the IVHM and removed to IDS using the CLEM. If decay heat rates exceed $10 \mathrm{kWt}$ per subassembly, the fuel will be transferred from the core to an IVSM storage position using the IVHM. Fuel stored in IVSM will remain there until decay heating is less than $10 \mathrm{kWt}$ per subassembly, at which time it can be moved to the transfer location when the reactor is shut down, using the IVHM, for subsequent removal by the CLEM. Calculations indicate that least 29 outer driver assemblies in an optimum array are required to achieve a critical configuration; therefore, the 19 positions in an IVSM, if totally filled, provide a safe array. Interaction between the core and these modules and also between modules does not increase reactivity significantly because of the intervening materials. It is not possible to place two assemblies in a single IVSM position, and the mechanical structure maintains a minimum spacing between assemblies. The IVSM and IVHM are adequately designed from the standpoint of criticality considerations.

\section{F. Interim Examination and Maintenance (IEM) Cell}

The IEM Cell has a basic functional objective of providing a reliable means of retrieving data from irradiated fuel while maintaining controlled environmental conditions. In addition, the IEM Cell processes irradiated fuel for off-site shipment, and performs limited maintenance on contaminated or radioactive plant equipment. The sealed shielded cell is equipped with manipulators, cranes, viewing windows, and specialized remote handling equipment. The IEM Cell is designed to accommodate individual sodium-wetted irradiated fuel assemblies with decay heats of up to $7 \mathrm{kWt}$. Irradiated fuel is brought to the IEM Cell by using the CLEM and is transferred through either of two smaller-diameter valves in the IEM Cell ceiling valve.

The maximum decay heat removal capability of the argon atmosphere in the IËM Cell is $18 \mathrm{kWt}$, and the number of irradiated fuel assemblies to be 
located within the IEM Cell at any one time is to be limited administratively by FSAR, Chapter 20, FFTF Criticality Specifications. The logistics of the confined cell space will likely limit this to two assemblies. Individual fuel pins are to be nondestructively examined, including dimensional checks, weighing, gamma scanning, visual inspection, and photography. Disassembly of the fuel will take place in the IEM Cell annex, where the pins will also undergo examination and will be stored temporarily. No criticality problem is associated with the fuel assemblies or packaged pins, because these will remain safely subcritical under any potential accident condition. (27)

Administrative control will be required to account for all pins from the disassembled fuel element. Because the 217 pins in an assembly are more than adequate to form a critical assembly if appropriately spaced and moderated (see Table 11.1-4), administrative controls will be required to maintain safe storage of the individual pins and to ensure that no moderator can inundate the stored pins. When examination of the pins is complete, the pins are to be placed in a container and sealed for subsequent offsite shipment. The number of pins in the sealed container is limited to ensure thermal safety and is more than adequate to ensure criticality safety under any moderating or other accident condition.

\section{G. Test Assembly Conditioning Station (TACS)}

The TACS performs an analogous function to the CCCS for the longer fuel test assemblies. There are 27 storage positions in the TACS, with an inert gas atmosphere.

Design features disallow insertion of assemblies into interstitial positions, thus limiting the number of contained assemblies to 27 . As the critical number of outer driver fuel assemblies in gas is 33 when tightly packed (Table 11.1-3), this facility is subcritical as designed for the present enrichment and quantity of fuel in outer driver fuel assemblies. 
In the unlikely event of Mobiltherm flooding (Table 11.1-1), analyses show TACS would remain subcritical because of large spacing (14-1/2 in.) between assemblies, a spacing ensured by the mechanical design.

The storage array must remain subcritical under the worst-case postulated conditions. These conditions would consist of concurrent flooding of the TACS with Mobiltherm or water and an independent seismic event. Under these conditions, criticality can be postulated in the TACS New Storage Vault and in the Radioactive Storage Vault if the grid spacer fails, allowing the fuel assemblies to swing freely in the fully moderated condition. (28) To preclude such a criticality, the number of fueled assemblies allowed to be stored in each vault is administratively controlled to limits in Chapter 20.

\section{H. Cask Loading Station}

The Cask Loading Station, located in the RSB, includes equipment for handling irradiated reactor core components and equipment. Irradiated fuel exits from the containment Building through the equipment airlock in the BLTC. The fuel is transferred from the BLTC to the shipping cask, which is positioned in the Cask Loading Station (CLS). Offsite shipment of FFTF fuel assemblies to examination facilities will comply with the cask criticality requirements. The BLTC single, core component transfer operation at the CLS and the shipping cask single assembly capability are judged to be inherently safe from the standpoint of criticality.

I. Manually Operated Rail Kart (MORK) and Multipurpose Rail Transporter (MPRT)

Driver fuel assemblies are received in the RSB in a Radial Reflector Shipping Container (RRSC) transported into containment on the MORK or the MPRT. Each RRSC can hold up to four fuel assemblies, and two containers can be transported simultaneously on the MORK or the MPRT. The construction of the RRSC provides a minimum spacing of 20.5 in. between assemblies in adjacent containers. Eight containers with four assemblies each cannot be made critical (see Table 11.1-3). Two containers each 
containing four fuel assemblies would remain subcritical even if the containers were flooded with Mobiltherm (see Table 11.1-1). The Mobiltherm is a better moderator than water.

J. Core Component Handling Machine (CCHM) and Component Test Assembly Service Stand (CTASS)

The RRSC strongback is uprighted and secured to the CCHM or CTASS for inspection and insertion of the fuel assemblies into the inerting cells. One storage location is provided on the CCHM with provision for two storage locations spaced $7.5 \mathrm{ft}$ center to center. One storage location is provided on CTASS. The greatest concentration of assemblies would result from one fully loaded strongback in a storage location with one assembly supported from the crane in close proximity to the strongback. Flooding is not possible in a vertical attitude, and this configuration would remain subcritical (see Table 11.1-3).

K. Temporary Drive Fuel and Test Assembly Inerting System

New fuel or test assemblies will be inserted one at a time into the temporary inerting cells. Each cell consists of a tube installed at a TACS location. The diameter of the tube makes it impossible to insert mure thain one assembly. A single assembly in the incrting ccll would bo subcritical even in the unlikely event that the cell might be flooded with Mobiltherm (see Table 11.1-1).

L. Storage and Handling Requirements for Fueled Assemblies in the RSB and RCB

These requirements are contained in the criticality Safety Specifications, which are in FSAR Chapter 20.

M. Component Loading/Unloading Equipment (CLUE)

Up to twelve Cycle One and/or characterizer core components (maximum enrichment $29.3 \% \mathrm{Pu}$ ) will be transferred from the Radial Reflector 
Shipping Container (RRSC) to the CLUE tank and placed in receptacles within the tank that will maintain proper spacing. This loading is done using the NIH-3 grapple and the polar crane. Flooding of the CLUE would appear to be impossible, but in any event, the 12 core components would remain subcritical (maximum $k_{\text {eff }} 0.76$ ) caused by the component spacing ensured by the receptacles within the CLUE tank. It would take three very unlikely events to cause a criticality within CLUE as follows:

1. A seismic event that could fail the receptacles and allow the 12 core components to come in close contact

2. Some external force to pack the core components into the ideal spacing

3. A flooding of the CLUE tank.

The CLUE will be installed over the open IDS port when the IDS contains irradiated core components. For the loading of Cycle One and/or characterizer core components these irradiated core components will have a power level of approximately $0.3 \mathrm{~kW}$. The calculated dose rates are as follows:

1. At the top of the CLUE tank

From core components surrounding the open port -- $14.5 \mathrm{mRem} / \mathrm{h}$

From core component directly under the open port -- $150 \mathrm{mRem} / \mathrm{h}$

Total $164.5 \mathrm{mRem} / \mathrm{h}$

2. Around the base of the CLUE tank (550' level)

From core components surrounding the open port -- $58 \mathrm{mRem} / \mathrm{h}$

From core components directly under the open port -- $20 \mathrm{mRem} / \mathrm{h}$

Total $78 \mathrm{mRem} / \mathrm{h}$

The plan is to load from the CLUE into empty IDS positions that do not have any irradiated core components surrounding them. Also the movement of the IDS basket will be planned such that irradiated core components will not pass under the open port under the CLUE. This will preclude any radiation exposure to operating personnel caused by the irradiated core components in the IDS. 
NOTES:

1. If it becomes necessary to move the IDS basket such that an irradiated core component passes the open port under the CLUE, the following precautions will be taken to limit the radiation exposure of operating personnel:

a) All personnel will be removed from the top of the CLUE tank

b) The area around the base of the CLUE tank will be roped off to prevent personnel access.

2. If it becomes necessary to load a core component into an empty IDS position with irradiated core components surrounding it, the following precautions will be taken to limit the radiation exposure of operating personnel:

a) The area around the base of the CLUE tank will be roped off to prevent personnel access

b) A review of the calculated dose rates shows that the dose rate at the top of the CLUE tank is $14.5 \mathrm{mRem} / \mathrm{h}$. This is acceptable for limited personnel exposure time. Therefore, precautions will be taken to 7 imit the exposure time of the operating personnel.

\section{N. I-3 Cask}

The T=3 cask will be loaded in the CLS by the BLTC. Only one fuei assembly or pin container may be contained in the T-3 and it will remain subcritical even if flooded with Mobiltherm (see Table 11.1-1).

\section{SERF Cask}

The SERF cask may be loaded in the TACS New Storage Vault by the CLEM or in the CLS by the BLTC. The SERF cask will only be loaded with one pin container with a maximum of 30 pins and will remain subcritical even if flooded with Mobiltherm (see Table 11.1-4). 
P. Top Loading Fuel Transfer Cask (TLFTC)

The TLFTC is loaded in the TACS New Storage Vault by the CLEM or in the CSL by the BLTC. The TLFTC payload consists of a sodium-filled CCP and a fuel assembly or Ident 69 pin container. The fuel assembly can be either irradiated or nonirradiated. The fuel in the TLFTC remains subcritical even in the unlikely event that the cask were to be flooded with Mobiltherm (see Table 11.1-1).

\section{Q. Solid Waste Cask (SWC)}

The SWC is used to transport radioactive waste from the IEM Cell directly to the CLS where it is loaded into the Disposable Solid Waste Cask (DSWC) or from the IEM Cell to the MASF for sodium cleaning and then to the CLS, or from the Solid Waste Transfer Pit (SWTP) to the MASF for sodium cleaning and then to the CLS. Waste is enclosed normally in a sixposition waste container. The waste container is sized to accept six core components, such as reflectors, in-core shims, and control rods. Because of this size, it is possible to place six fuel assemblies into the waste container if it is loaded in the SWTP by the BLTC. In the extremely unlikely event of this happening, since the FFTF Inventory Control System would preclude the six transfers required, the waste container would remain subcritical even if immersed in water during cleaning at the MASF (see Table 11.1-1).

\section{R. Disposable Solid Waste Cask (DSWC)}

In the CLS, the DSWC is loaded by the SWC. The waste is enclosed normally in a six-position waste container. In the unlikely event that six fuel assemblies were loaded into the waste container and the cask flooded with water, it would remain subcritical (see Table 11.1-1). 


\subsection{Error Avoidance in Fuel Handling Operations}

There are points where errors might occur in the interaction between the requirements of the Reload Design Report (RDR), the Detailed Refueling Plan (DRP), the associated procedures to carry out specific moves, the sequences of procedures to accomplish total routing from receipt onsite to departure for an assembly, and the response of the machine or facility to carry out the required action. These errors are precluded or reduced to an economic type of problem, e.g., lost time, through the use of established and proven procedures, sequences, and machine computer programming.

At the same time, there is a strong incentive to reduce the shutdown time of the reactor for refueling, and provide flexibility in the operation where safety is not involved. Additionally, it is important not to increase the complexity of the system with excessive interlocks or to lock out a proper response by an operator in an offnormal event. Based on the planned procedures and sequences, the content of the DRP, and the administrative control, the defined Inventory Control System assists the operators in safely and expeditiously executing FFTF fuel handling functions.

A. The DRP is the guiding document for the refueling operations. Only one RDR will be in effect that defines core and In-Vessel Storage Module (IVSM) inventory. Systematic preparation of the DRP will follow administrative guidelines to implement both the needs of reactor operation and the goals of the test program. The draft copy will then be reviewed in depth by the affected disciplines, such as Core Physics. Signoff of the final copy by these disciplines and the approving authority will ensure to a high degree that all precautions have been taken. The DRPs are generated using the confirmed core map found in the RDR and are consistent with requirements in the various SDDs. For instance, the fuel assemblies handled by the CLEM must not exceed $10 \mathrm{kWt}$ unless CLEM is shown to be more capable); one of the two doors of the airlock must be closed whenever the reactor is operating (administrative procedure); and CLEM will not remove assemblies from the CCCS-North location (physical impossibility). 
B. The identified fuel handling sequences with the associated procedures constitute a framework that is necessary for the implementation of the DRP, but this also serves as a cross-check for errors in the RDR because a new or different requirement imposes the need for a new procedure or a different handling sequence. The combination of review by the knowledgeable disciplines and comparison to proven procedures following approved handling sequences provides a high degree of confidence that a safety-related error will not originate with the DRP.

C. Finally, the IVHM refueling sequence tapes will be cross-checked before use to ensure that they correctly implement the RDR when used sequentially from beginning to end. If tapes are alternated because of problems in one sector or to facilitate optimum refueling, the DRP will ensure that all safety-related factors have been checked before any action. Further, it will ensure a return to safe operation in the original sector. 
0. Refueling Support System

Loss of power to these facilities and both mobile and portable equipment has no direct safety impact.

P. Hypothetical Accident Evaluation

The HCDA directly involves only the mechanical part of the IVHM. This is discussed in Section 11.2 of this document. The potential effect of the HCDA on the RRS is to deny access to Containment, and the system components have been shown to be safe under similar conditions in the foregoing discussion. Action following this event will not prevent safe shutdown of the plant, containment isolation, or protection of the public.

\section{1 .5 REFERENCES}

1. CLEM Cold Wall Emissivity Tests - Final Report $(30,60,100$ day $700^{\circ} \mathrm{F}$. Sodium Soak), TR-681-414-002, Atomics International, June 22, 1972 .

2. Fuel Storage Facility Final Safety Analysis Report, HEDL-TI-75328.

3. Thermal and Process Analys is of the Interim Decay Storage (IDS), VITRO-R-212, Addendum 1, March 1975.

4. Thermal and Process Analys is of the Interim Decay Storage (IDS), VITRO-R-212, May 1973.

5. Reactor Fuel Transfer Port Floor Valves Adapter Stuck Fuel Assembly Analysis, VITRO-R-404, December 1975.

6. M. V. Collins, Seismic Analysis of Core Component Pot, HEDL Report, October 1975.

7. M. V. Collins, Seismic Analysis of Fuel Driver Assembly in CCP, in CLEM, HEDL Report, October 1975.

8. M. V. Collins, Seismic Analysis of Floor Valve, HEDL Report, October 1975.

9. Letter, T. J. Cranley to C. L. Boyd, "Fuel Handling Equipment Seismic Impact on CLIRA," July 1975.

10. M. V. Collins, FFTF Fuel Handling Equipment, Stress Analysis of Fuel Driver Duct in BLTC for Seismic. (DBE) Loads, HEDL Report, November 1975. 
11. M. V. Collins, IACS Category I Seismic Analysis, HEDL-SR-TACS-01, August 1975.

12. M. V. Collins, CCCS Category I Seismic Analysis, HEDL Report, August 1975.

13. Smal1 Tools Transfer Lock Doors Seismic Analysis, AMCO Report, 02-M-143, Rev. B, January 1975.

14. Seismic Analysis for Cell Ceiling Valve, AMCO Report, 02-M-159, Rev. C, July 1975.

15. Thermal Analysis of a Bare FFTF Driver Fuel Assembly, VITRO-R-383, July 1975.

16. Memo, J. C. Guzek to G. R. Franz, "IDS Maximum Decay Heat Revised to $155 \mathrm{~kW}, " \mathrm{~T} / \mathrm{H}: 86-105$, June 9, 1986.

17. NE Standard F 2-2, "Quality Assurance Program Requirements."

18. NE Standard F 2-4T, "Quality Verification Program Requirements."

19. ASME Boiler and Pressure Vessel Code.

20. NE Standards E 15-2T, "Requirements for Nuclear Components."

21. Industrial standards, American Society for Testing Materials.

22. Industrial standards, National Electrical Manufacturers Association.

23. DOE Order 5480.1B, "Environment, Safety, and Health Program for Department of Energy Operations."

24. JABE-WADCO-02, Rev. 2, Seismic Design Criteria for the Fast Flux lest Facility, July 1975.

25. FFTF Safety Assurance Summary, HEDL-TME 75-76.

26. U.S. Nuclear Regulatory Commission, Certificate of Compliance for Radioactive Materials Packages, Number 9132, latest revision.

27. C. A. Rogers, Exemption of IEM Cell from Criticality Alarm Coverage, NCS Memorandum W81-15, HEDL-TI-75342, August 3, 1981.

28. S. L. Bahtia, "Justification for Fuel Handling and Storage at FFTF Without a Criticality Alarm System," WHC-SD-SQA-CSA-20303, Westinghouse Hanford Company, Richland, Washington, April 20, 1990. 
sections require additional stiffening to prevent failure of the pressure boundary. These will be strengthened and re-analyzed before delivery to the FFTF. The CLEM will survive the DBE upright with the pressure boundary intact and the natural convection cooling system operating. As in paragraph 11.3.4.2G, the ensuing loss of power on the plant will not prevent maintenance of safe temperatures for a contained 10-kWt assembly.

I. Failure of Suspension System to Cause Grapple Freefall

There are two grapples available for use by the CLEM: a short unit (5 ft) is used when handling test assemblies, and a long unit (32 ft) is used when handling assemblies contained within a CCP. Grapples are usualiy exchanged remotely within the IEM Cell or at the CLEM grapple changer located in the CLEM maintenance pit. Either grapple is attached by four bolts to the head piece, which is part of the grapple chain suspension system. The head piece is supported by two, triple-strand roller chains. Also pinned to the head piece is a double-strand actuator rod chain.. Each of the three chains is capable of supporting either grapple, including maximum suspended load.

A component load capacity diagram and fault tree-type analysis has verified that adequate loading margins and redundant support mechanisms exist within the grapple and suspension system. Grapple freefall would require at least a double failure within the suspension system. 


\subsubsection{REFERENCES}

1. S. Berger, Closed Loop Ex-Vessel Machine Conceptual Design Shielding Analysis, AI Report TI-681-414-017, June 8, 1971.

2. S. Berger, Viewport Shielding Analys is for CLEM, AI Report TI-681-414-076, November 22, 1972.

3. S. B. Moore, Maximum Probable Pressure Fluctuation in CLEM During Refuel ing Report No. 2, AI Report TI-681-414-063, June 13, 1972.

4. J. Kleinpeter, Reactor Floor Valve Adaptor. Stuck Fuel Analysis, VITRO-R-404, Decomber 1975.

5. S. B. Moore, Thermal Analys is of Floor Valve with Stuck 10 Kwt Fuel Assembly, AI Report TI=681=414=020, July 17, 1971.

6. R. Craig, Circumferential Temperature Profile in CLEM Cold Wall During Preheating, AI Report TI-681-414-034, September 10, 1971.

7. R. Craig, CLEM Flange Temperature Profiles and Module VII Iemperature Distribution, AI Report TI-681-414-035, September 10, 1971.

8. J. Brukiewa, Temperature Distribution in CLEM Module II Under Emergency Cooling Conditions, AI Report TI-681-414-038, February 16, 1972.

9. S. B. Moore, Ihermal Analysis of CLEM Grapple Uuring Insertion into a $450{ }^{\circ} \mathrm{F}$ Sodium Pool, AI Report TI-681-414-052, March 1, 1972.

10. S. B. Moore, Thermal Analys is of CLEM Viewport with a Stuck 10 KWT Fuel Assembly, AI Report TI-681-414-053, March 2, 1972.

11. W. D. Pearson, CLEM Decay Power Handling Capability, AI Report TI-681-414-044, December 23, 1971.

12. E. M. Mouradian, Thermal Performance of CLEM with Emergency Cooling Condition, TI-681-414-001, Apri1 23, 1971.

13. R. Postma, CLEM Seismic Stress Analysis, SR-681-414-001, June 1975. 


\subsection{TACS Inerting and Preheating (IP) Vault}

The TACS inerting and preheating vault consists of three IP cells and a heater cell. The IP cells are used for conditioning with argon and holding at temperature, new reactor test assemblies up to $42 \mathrm{ft}$ in length (including grapple adapter) for transfer by the CLEM to the reactor. The heater cell is similar to the CCCS heater cell and houses the Heater Assembly that provides $15 \mathrm{~kW}$ maximum power for heating of the inert gas (argon) that is used to condition the new test assemblies.

Cooling nitrogen from System 25 flows up through the IP vault to maintain $100{ }^{\circ} \mathrm{F}$ average wall temperature.

\subsection{TACS New Storage Vault}

The TACS New Storage Vault, located immediately east of the IP vault, is designed to store up to 12 new test assemblies. However, administrative controls limit the number of fueled assemblies that may be stored in the vault (see Section 20.4.1, Chapter 20). The 46-ft deep vault is argon filled and supports new test assemblies from their grapple adapters in an open vault. The top shield plate is removable to provide space for lowering a CLEM coldwall container into the vault during cold-wall exchange.

The top shield plate can be removed and replaced with a SERF Cask support that will provide the necessary structural support for the SERF Cask. This will provide a temporary facility that can be made available whenever it is necessary to load the SERF Cask in containment.

The facility is made available by removing an existing top shield plate from the New Storage Vault and replacing it with a SERF Cask support (see Figure 11.6.6). This support is rectangular (to fit cell opening), 
45.0 in. $\times 64.12 \times 15.0$ in. high with a 4.0-in.-thick top plate. The top plate has a 43.63-in.-diam hole to accommodate the SERF Cask adapter flange. The SERF Cask, through the adapter flange, interfaces with the FFTF refueling floor valve. The dead load of the SERF Cask, floor valve, and CLEM movable closure valve is carried by the SERF Cask support to the main structure of the New Storage Vault.

\subsection{TACS Radioactive Storage Vault}

The Radioactive Storage Vault is designed to provide eight shield storage locations for radioactive and contaminated test assemblies and test assembly components. However, administrative controls limit the number of fueled assemblies that may be stored in the vault (see Section 20.4.1, Chapter 20). This storage vault is also $46 \mathrm{ft}$ deep, argon filled, and supports the assemblies from the grapple adapter in an open vault. The design is for 90-day decayed tests. ${ }^{(5)}$

\subsection{TACS Recycled CLIRA Storage Vault}

The Recycled CLIRA Storage Vault is located immediately east of the New Storage Vault and immediately south of the Radioactive Storage Vault. Recycled CLIRA fuel assemblies will be stored in three, 43-ft-deep cells located within this vault. Both heating and cooling, and separate isolation argon purge capability are provided for recycled sodium-filled CLIRA units to maintain the test assembly duct temperature between 250 and $600{ }^{\circ} \mathrm{F}$ while in this storage position. The design is for a 90-day decayed test, generating a maximuin 
The conditioning stations were designed to meet Section III of the ASME Code $^{(20)}$ without Code stamping. Materials were procured to ANSI ${ }^{(22)}$ B-31.1. Welding and inspection requirements were per Section III, Class $2,{ }^{(20)}$ for the recycled CLIRA cells and Class 3 for all other cells. The Stress Reports ${ }^{(10,11,12)}$ demonstrate compliance with the Section III, Class 2 and Class 3 Code stress requirements. Positive margins of safety were found for all components in the drop-load accident cases except for the sacrificial honeycomb that crushes to absorb the impact energy.

An analysis to determine the subcritical condition of TACS storage vaults indicated that a maximum $k_{\text {eff }}$ of 0.7 would exist for a postulated situation where all storage locations are occupied by fueled test assemblies and the vault is flooded with Mobiltherm or water glycol. (13)

When two independent, concurrent events were considered, i.e., flooding and seismic events, it was postulated that criticality might occur in either the New Storage Vault or the Radioactive Storage Vault. This criticality is postulated on the failure of the spacer grid assemblies, allowing the fuel assemblies to swing freely in the fully moderated condition. (23) To preclude such a criticality, the number of fueled assemblies allowed to be stored in each vault is administratively controlled to limits in Chapter 20.

A stress analyeis was performed on the SERF Cask Support Structure and the TACS New Storage Vault Structure. This analysis included consideration of the combined static load of the SERF Cask loaded, the floor valve, and CLEM Movable Closure Valve. Based on this analysis, the stress produced in the vault structure and in the SERF Cask support is below the allowable stress levels for the material used. To verify structural integrity, the SERF Cask support was load tested after fabrication with a total weight of 165,000 lb. This is $50 \%$ greater than the total expected static load. Additional radiation shielding has been designed that will provide protection at the 550-ft level from radiation emitted from a source located in an IEM cell streaming through an argon-circulating wall duct when the cell shield plug is removed to install the SERF Cask. This shielding is provided in the form of a labyrinth of steel louvers that are placed in the rectangular opening where the duct penetrates the cell wall. A framework 36 in. by 36 in. by 18 in. deep contains the 
steel louvers and is fitted into the existing ductwork. The arrangement of the louvers provides an equivalent of $6 \mathrm{in}$. of steel shielding while allowing passage of the argon through the ducting. This shielding limits the dose rate on top of the conditioning station (550-ft elev) to $0.2 \mathrm{mRem} / \mathrm{h}$. A source of radiation has been identified that may compromise the allowable radiation levels at the 550-ft elevation. This source is an irradiated CLIRA stored in an adjacent recycled CLIRA Storage Cell. This condition will not exist until a CLIRA has been cycled through the reactor and brought to this storage cell. Additional shielding will be provided before this event occurs.

\subsection{Temporary Inerting Systems}

\subsection{Temporary DFA Inerting Cell}

A stress analysis has been performed for the temporary driver fuel inerting cell. The analysis included consideration of the combined static load of the cell plus the weight of a CCP, the heaviest assembly to be handled (620 1b), and the CLEM grapple weight resting on the cell. Additionally, the application of a sudden load consisting of the CCP, the heaviest assembly, plus the weight of the CLEM grapple was also analyzed for stress levels produced in the inerting cell during handling operations. Finally, an analysis was performed for the offnormal condition where the CLEM Movable Valve fails to stop when first contacting the inerting cell seal plate and continues to move down until stopped by the mechanical stop on the CLEM, resulting in maximum compression of the inerting cell's support springs. Based on these analyses, the stress produced in the cell is significantly less (max. stress less than 1,000 psi for static and offnormal load condition and less than 2,500 psi sudden load condition) than the yield strength of the 304 stainless steel material used for construction. The only exception to this is the 10-in. vacuum gate valve, which experiences a compressive load during the offnormal condition. To verify structural integrity, the valve was compressively tested in a load testing machine to ensure compressive load carrying capability for the offnormal condition. Based on test results, the valve performed satisfactorily at loads up to nearly three times the maximum offnormal load condition with no indication of incipient failure. 
underside of the top shield plates. These seals maintain the inert atmosphere and no significant amount of gaseous contamination will occur. Argon purge procedures, to System 82 processing, and the seal system design provide backup protection. (7)

Radiation protection is provided by the thick top shield plates, plugs, and surrounding concrete or heavy steel walls that attenuate radiation from components within, including radiation streaming through the stations from adjacent sources. The CCCS TC liner wall is $1.25 \mathrm{in}$. thick, embedded in concrete. A 6-in. steel wall north of the TC attenuates IDS sources and a 3-in. steel wall in the equipment gallery south of the cell provides protection during transfer operations. The Recycled CLIRA and Radioactive Storage TACS Vaults are enclosed by a 3-ft-thick concrete wall, which is common with the IEM cell on the north side, and three, 6-in.-thick steel walls on the remaining three sides. Additionally, the south and west walls are increased in thickness at the elevation of the stored activated tests to provide for limited access to the adjacent pipeway. Adequate shielding is provided to limit the dose rate on top of the Conditioning Stations to $0.2 \mathrm{mRem} / \mathrm{h}$ and limited access areas adjacent to the sides of the stations to $5 \mathrm{mRem} / \mathrm{h}^{(5,6)}$ design or $2 \mathrm{mRem} / \mathrm{h}$ averaged over $1 \mathrm{yr}$.

Subcritical storage of the test assemblies in the TACS is provided by sufficient geometric spacing to decouple the stored assemblies. ${ }^{(13)}$ Grid plates are provided in the storage locations of the New and Radioactive Storage Vaults to ensure that the spacing is maintained in the event that a disruptive force occurs, which would tend to modify the storage lattice spacing. However, because the grid spacers have not been seismically qualified, the number of stored, fueled assemblies is administratively controlled. These controls ensure that a criticality cannot occur in either the New or Radioactive Storage Vault. The CCCS services only one fuel assembly at a time in each station and SPSS-1 stores only nonfissile shield plugs; therefore, these stations do not have criticality considerations. No criticality condition will occur in these facilities.

The inert atmosphere of the stations minimizes the possibility of a fire. Cells are normally filled with dry argon and are located in nitrogen-filled vaults. 


\subsubsection{Protective Features Evaluation}

\subsection{Conditioning Stations}

Design features are provided to minimize the effect of potential off-normal occurrences such as dropping of a sealed transfer container or test assembly from the maximum loading height. The design provisions to prevent this have been evaluated. In addition, the Conditioning Stations are designed to withstand loss of power in seismic events. These protective features are discussed in this section.

The cCcS transfer cell is designed to accommodate a drop load energy level of $34,400 \mathrm{ft}-1 \mathrm{~b}$, which is postulated to occur from the transfer container ( $370 \mathrm{lb}$ ) and grapple (1500 lb) dropping $20 \mathrm{ft}$ (maximum height) into the TC. The cell was found to be capable of absorbing the energy without rupturing. ${ }^{(10)}$ The drop load energy is absorbed by crushing the honeycomb structure in the bottom of the cell. This item is considered sacrificial in the dropping case, and is replaceable.

The TACS IP and recycle CLIRA storage cells are designed to accept the drop load with an energy of $140,000 \mathrm{ft}-1 \mathrm{~b}$, which is postulated to occur from dropping a test assembly $(1300 \mathrm{lb})$ and the CLEM grapple $(1500 \mathrm{lb})$ a distance of $50 \mathrm{ft}$ into the cells. It was found that the TACS cells could absorb the drop load energy without rupturing. (11) The energy was absorbed in yielding the upper support liner and by crushing the honeycomb absorber column, both of which are considered sacrificial for the drop load event.

Transient analyses of CCCS and TACS following an outage of primary and backup electrical power sources have indicated that the maximum $c l$ ad temperatures of decaying pins in transfer containers or recycled CLIRA assemblies reach the $1500^{\circ} \mathrm{F}$ emergency fuel pin cladding temperature limit, ${ }^{(8,9)}$ but are judged to be safe with no release to occupied areas.

Analyses of off-normal conditions show that the CCCS TC and TACS Recycle CLIRA cells which have been designated Category III, have been analyzed to meet the requirements of seismic Category I. ${ }^{(19)}$ Furthermore, the CLIRA pressure boundary will not incur gross failure under Design Basis Earthquake (DBE) loading and produce a release to the cell. During the DBE the maximum stress in the TACS cell wall is 25,800 psi (allowable is 30,400 psi). Under 


\subsubsection{REFERENCES}

1. CCCS Loop and Blower Design Operating Conditions, TI-681-413-067, Revision A, February 8, 1973.

2. Getter-Heater Thermal Analysis, TI-681-413-072, Revision A, February 8, 1973.

3. IACS Inerting and Preheat LOop Design and Operating Characteristics, TI-681-413-070, Revision A, February 8, 1973.

4. Thermal Analysis of the Heating and Insulation Requirements for the IACS Recycle CLIRA Storage Cell, TI-681-413-057, Change No. 1, October 25, 1972.

5. Shielding Analysis for TACS (Test Assembly Conditioning Station), TI-681-413-025, Revision A, November 1, 1972.

6. Shielding Analysis for CCCS (Core Component Conditioning Station), TI-681-413-071, November 17, 1972.

7. CCCS - New Fuel, Recycle and Transfer Cell Gas Leakage Requirements, TI-681-413-053, Revision B, February 8, 1973.

8. CCCS Transfer Cell Thermal Analysis, VITR0-R-407, January 1976.

9. TACS Recycle Cell Thermal Analysis, VITRO-R-405, December 1975.

10. Structural Analysis - CCCS Components, TI-681-413-080, August 8, 1973.

11. Structural Analysis, TACS and SPSS No. 2 Components, TI-681-413-082, April 10, 1974.

12. Structural Analysis - SPSS No. 1. Components, TI-681-413-079, August 3, 1973.

13. Results of TACS Criticality Study, CAM 17-87, May 14, 1973.

14. Installation Requirements Document for Shield Plug Storage Station, T-151, T1-681-413-083, Revision 1. December 18, 1974. 
15. Installation Requirements Document for the Test Assembly Conditioning Station. T-37, TI-681-413-086, Revision 1, December 18, 1974.

16. Installation Requirements Document for the Core Component Conditioning Station. T-71, TI-681-413-087, Revision 1, December 18, 1974.

17. M. V. Collins, CCCS Category I Seismic Analysis, HEDL Stress Report, August 21, 1975.

18. M. V. Collins, IACS Category I Seismic Analysis, HEDL Stress Report, HEDL-SR-TACS-01, August 7, 1975.

19. Seismic Design Criteria of the Fast Flux Test Facility, Richland, Washington, JABE-WADCO-02, Rev. 2, July 1975.

20. ASME Boiler and Pressure Vessel Code, Section III, Nuclear Power Plant Components.

21. Uniform Building Code.

22. Amertian National Standards Institute.

23. S. L. Bahtia, "Justifiçation for Fuel Handling and Storage at FFTF without a Criticality Alarm System," WHC-SD-SQA-CSA-20303, Westinghouse Hanford Company, Richland, Washington, April 20, 1990. 


\section{CONTENTS (Cont'd)}

\subsubsection{RADIATION PROTECTION DESIGN FEATURES}

Page

12.2.3.1 Facility Design Features

$12.2-20$

12.2.3.1.1 Shielding for Design Basis Events

$12.2-20$

12.2.3.1.2 Biological Criteria

$12.2-21$

12.2.3.1.3 Material Criteria

$12.2-21$

12.2.3.1.4 Facility Design Example

$12.2-24$

$12.2-25$

$12.2-27$

12.2.3.2.1 Reactor Shield Description

$12.2-28$

12.2.3.2.2 Reactor Containment Building Shields

12.2-29

12.2.3.2.3 Reactor Support Building Shields

12.2-31

12.2.3.2.4 Main Control Room Shielding

$12.2-32$

12.2.3.2.5 Other Plant Areas

$12.2-33$

$12.2-33$

$12.2-33$

12.2.3.3.1 Design Bases

$12.2-33$

12.2.3.3.2 Design Description

12.2-34

$12.2-34$

$12.2-36$

12.2.3.4.2 Airborne Radioactivity Monitoring

12.236

12.2.3.4.3 Operating Procedures

12.2-37

$12.2-38$

$12.2-38$

$12.2-38$

12. $2-38$

12. $2-38$

$12.2-40$

12.2-41

12.2-41

12,2.5.2.1 Facilities

$12.2-42$ 


\section{CONTENTS (Cont'd)}

12.2.5.2.3 Portable Radiation Instruments

Page

12.2.5.2.4 Specifications

$12.2-43$

12.2.5.2.5 Calibrations

$12.2-43$

12.2.5.2.6 Air Sampling

$12.2-44$

12.2.5.2.7 Protective Clothing and Respirators

$12.2-46$

12.2.5.2.8 Supplied Breathing Air System

$12.2-46$

$12.2-47$

12.2.5.3 Procedures

$12.2-48$

12.2.5.3.1 Radiation Surveys

$12.2-48$

12.2.5.3.2 Control Programs for ALAP Occupational Radiation Dose

$12.2-48$

12.2.5.3.3 Control of Access and Residence Time

$12.2-49$

12.2.5.3.4 Protection Against Airborne Radioactivity

$12.2-50$

12.2.5.3.5 Routine Radiation Safety Audits

$12.2-52$

12.2.5.3.6 Training Program

$12.2-53$

12.2.5.4 Personnel Dosimetry

$12.2-55$

12.2.5.4.1 External Dose Measurement

$12.2-55$

12.2.5.4.2 Internal Dose Measurement

$12.2-57$

12.2.5.5 Sample Processing

$12.2-61$

12.2.5.5.1 Effluent Sample Processing

$12.2-61$

12.2.5.5.2 Environmental Sample Processing

$12.2-66$

12.2.5.6 Radioactive Materials Safety and Security

$12.2-67$

12.2.5.6.1 Materials Safety Programs

$12.2-67$

12.2.5.6.2 Personnel and Procedures for Safety and Security

$12.2-68$

12.2.5.6.3 Control Levels for Radioactive Materials

$12.2-68$

12.2.5.6.4 Shipment and Receipt of Radioactive Material

12. $2-70$

12.2.5.7 Records

12. $2-71$

12.3-1

\subsection{REFERENCES}


The primary purpose of the area monitors is to provide the radiation status at all plant locations and indications of any changes in radiation conditions. The locations of the monitors are determined by the following considerations:

1. The anticipated radiation level under operating, shutdown maintenance, and abnormal conditions

2. The frequency and duration of occupaney

3. The radiation sources and their proximity to the personnel

4. The flow of traffic under normal and emergency conditions

5. The consequences of possible undetected increase in radiation level.

A detailed description of the monitors and the design bases are provided in Section 7.3 and in SDD-96, "Radiation Monitoring System." The essential design features of the area monitors include:

1. Continuous measurement capability of gamma radiation level from 0.1 to $10^{4} \mathrm{mRem} / \mathrm{h}$

2. Continuous recording and display in the control room

3. High-high-level alarm with audible and visual indication at work locations and annunciation in the control room

4. High-level alarm with visual indication at work locations and annunciation in the control room

5. Loss-of-signal instrument failure annunciator in the control room with visual al arm at the work location.

A post-accident monitor (PAM) of containment provides continuous measurement cabability of high gamma radiation levels, from 1 to $10^{7} \mathrm{R} / \mathrm{h}$. The PAM also has design feature (5) and high and high-high visual alarms.

A functional diagram of the area monitoring channels is shown in Figure 12.2-2.

In addition to the local area monitors, the High Gamma Alarm System consisting of six gamma monitors is provided to detect high gamma activity and to sound an evacuation alarm. Two sets of three detectors each are provided to monitor the Reactor Service Building and Containment Building. A trip of two or more monitors from either set initiates an evacuation alarm. The monitors are positioned to detect radiation originating in fuel handling or fuel storage facilities and from the reactor primary system. 
The locations and specifications of equipment operational characteristics such as method of calibration and maintenance and calibration program of the area monitors is described in SDD-96. The type and locations of power sources and indicating and recording devices are also described in SDD-96.

The locations and specifications of the area monitors including type, range, alarms, and indicating devices are given in Table 12.2-2. The type and location of power sources, methods of calibration, and maintenance programs are described in SDD-96.

\subsection{Airborne Radioactivity Monitoring}

Fixed radioactivity monitoring instruments are used for service as process and effluent monitors or as area monitors. Sections 12.1.5, Process and Effluent Monitoring, and SDD-96, Radiation Monitoring System, provide a description of these monitors, including criteria used to determine:

1. Necessity for and location of instruments

2. Sampler and detector operational characteristics

3. Detector type, sensitivity, and range

4. Type and locations of power sources, and indicating and recording devices

5. Type and location of annunciators and alarms, and the system or operator actions they initiate

6. The maintenance and calibration programs to be followed.

Section 12.1.5 also describes the portable instruments and samplers to be used to check the fixed systems.

\subsection{Operating Procedures}

Plant operating procedures ensure that onsite exposures will be kept as low as practicable during plant operation and maintenance. A discussion of the Health Physics Programs is included in Section 12.2.5 and a discussion of the operation of ventilating systems during normal and offnormal operations is included in SDD-25, Heating and Ventilation System. 
In normally accessible areas where airborne contamination may exist, area monitors provide continuous measurement and alarm capability. The ventilation exhaust monitors discussed in Section 12.1.5 provide sensitive indication and alarm capability of the airborne radioactivity levels in exhaust from normally accessible areas. Periodic sampling of the ventilation systems with portable air samplers and analysis in the laboratory will provide a continuous assessment of the ambient airborne contamination levels and verify the accuracy of the fixed instruments.

Normally closed or inaccessible areas where airborne contamination may exist are also provided with continuous monitoring capability and are discussed in Section 12.1.5, Process and Effluent Monitoring. Whenever entry to these areas is required, the concentration of airborne radioactivity will be verified with portable sampling equipment. If airborne radioactivity is found to exist, the atmosphere will be purged to the CAPS until the radioactivity monitors indicate that the radiation level is safe for entry.

In areas where the airborne radioactivity cannot be removed or controlled by the ventilation system, appropriate measures will be taken to remove the source of the airborne radioactivity before personnel entry. These measures may include draining or purging of radioactive materials contained in equipment that is located in the area and removal of surface contamination from equipment and area surfaces. If a source of airborne activity cannot be removed or controlled, either occupancy will be restricted and/or respiratory protection equipment will be provided to maintain exposures within the guidelines of ERDAM Chapter 0524.

\subsubsection{Criticality Monitoring}

An evaluation of fuel handling and storage activities(27) has determined that a Criticality Monitoring and Alarm System is not required at the FFTF because of the physical form and the isotopic distribution of the fissionable materials handled. Additional details of the criticality considerations in the design of fuel handling and storage facilities are contained in Chapter 11. 


\subsubsection{DOSE ASSESSMENT}

\subsubsection{Shielding Basis to Limit Radiation Levels}

The shielding thicknesses are designed to reduce radiation levels from external sources to below the design dose rates, which were established to permit adequate operational access during operation of the plant. Maximum source strengths were employed in the shield design of the fuel handling equipment and the cover gas system. The shield walls were designed by approximating as closely as possible the actual geometry and physical condition of the source or sources. The sources were converted to a suitable energy group structure for calculational purposes. The final shielding thickness for each cell was designed to maintain the aggregate computed dose rate from all external sources of radiation at less than the design dose rate for the cell. In most cases the dose rate was evaluated at the point of maximum radiation through each individual wall. Therefore, the actual anticipated dose rate within a cell is expected to be less than the design dose rate.

Computer codes used in the shielding calculations for the reactor and $p l$ ant are listed in Table 12.2-3.

\subsubsection{HEALTH PHYSICS PROGRAM}

\subsubsection{Organization}

The organization, policy, and interrelations of authority and responsibilities for health physics functions for the HEDL, including the FFTF, are presented in Subsection 12.2.1.1 and Figure 13.1-9. The Health Physics Program is designed to maintain individual and total radiation exposure to ALAP.

\subsection{Health Physics Staff Qualifications}

The health physics program for the FFTF will be administered by the Manager, FFTF Health and Safety, who in turn reports to the Manager, HEDL Plant Safety. 
The Manager, FFTF Health and Safety, shall meet the following minimum requirements:

1. Graduate in Engineering, physical or biological sciences, or equivalent experience

2. Specialized training in health and safety or related fields

3. A minimum of $5 \mathrm{yr}$ of professional experience in the general field of safety, at least 3 of which shall have been in the nuclear facility

4. A minimum of 2 yr of supervisory or management experience.

Health Physics Engineer (reports to the Manager, FFTF Health and Safety) shall meet the following requirements:

1. Graduate in Engineering, physical or biological sciences, or equivalent experience 
TABLE 12.2-1

FFTF DRIVER ASSEMBLY SPENT FUEL RADIATION SOURCES AS A FUNCTION OF TIME AFTER SHUTDOWN, $\mathrm{T}_{8}$ (GAMMA SOURCE STRENGTH, $\gamma /$ SEC-ASSEMBLY).

\begin{tabular}{|c|c|c|c|c|c|c|c|c|c|c|}
\hline$E$ & \multicolumn{2}{|c|}{$\mathrm{T}_{\mathrm{s}}=1.0 \mathrm{~d}$} & \multicolumn{2}{|c|}{$T_{8}=20 \mathrm{~d}$} & \multicolumn{2}{|c|}{$T_{s}=140 \mathrm{~d}$} & \multicolumn{2}{|c|}{$T_{s}=274 d$} & \multicolumn{2}{|c|}{$T_{s}=365 d$} \\
\hline 3.0 & 1.45 & $(13)^{b}$ & 4.98 & (12) & 8.84 & (9) & 5.10 & (6) & 3.85 & (4) \\
\hline 2.7 & 1.77 & (12) & 2.10 & (10) & 4.22 & $(-1)$ & 7.43 & $(-14)$ & 3.24 & $(-22)$ \\
\hline 2.5 & 3.42 & (14) & 1.48 & (14) & 2.36 & (13) & 1.36 & (8) & 1.03 & (6) \\
\hline 2.3 & 3.68 & (13) & 7.24 & (13) & 3.22 & (12) & 2.48 & (12) & 2.08 & (12) \\
\hline 2.1 & 1.67 & (14) & 5.72 & (13) & 2.35 & (13) & 1.67 & (13) & 1.34 & (13) \\
\hline 1.9 & 6.79 & (14) & 1.68 & (13) & 5.30 & (10) & 9.13 & (7) & 1.41 & (6) \\
\hline 1.7 & 1.66 & (14) & 5.77 & (12) & 8.03 & (11) & 2.20 & (11) & 1.22 & (11) \\
\hline 1.475 & 1.26 & (16) & 4.35 & (15) & 3.06 & (13) & 1.47 & (13) & 1.20 & (13) \\
\hline 1.225 & 1.97 & (15) & 1.45 & (14) & 2.08 & (13) & 1.40 & (13) & 1.16 & (13) \\
\hline 1.0 & 3.87 & (15) & 7.05 & (14) & 6.06 & (13) & 4.11 & (13) & 3.41 & (13) \\
\hline 0.825 & 2.32 & (16) & 1.16 & (16) & 4.86 & (15) & 1.29 & (15) & 5.33 & (14) \\
\hline 0.65 & 3.3 & $(16)$ & 8.92 & (15) & 2.24 & (15) & 1.12 & (15) & 8.87 & (14) \\
\hline 0.475 & 3.03 & (16) & 1.12 & (16) & 1.75 & (14) & 6.62 & (14) & 5.03 & (14) \\
\hline 0.35 & 1.09 & (16) & 2.15 & (15) & 2.05 & (12) & 1.63 & (10) & 1.13 & (10) \\
\hline 0.25 & 1.61 & (16) & 4.62 & (14) & 4.62 & (13) & 1.07 & (13) & 4.23 & (12) \\
\hline 0.15 & 2.09 & (16) & 4.46 & (15) & 6.87 & (14) & 3.04 & (14) & 2.35 & (14) \\
\hline $\begin{array}{l}\gamma / \mathrm{sec}- \\
\text { assembly }\end{array}$ & 1.54 & (17) & 4.43 & (16) & 9.75 & (15) & 3.48 & (15) & 2.23 & (15) \\
\hline $\begin{array}{l}\text { Mev/sec- } \\
\text { assembly }\end{array}$ & 9.37 & (16) & 3.02 & $(16)$ & 6.66 & (15) & 2.28 & (15) & 1.39 & (15) \\
\hline
\end{tabular}

Based on an assembly power of $7.15 \mathrm{MW}$ and a 3 cycle-102 d/cycle burnup scheme with 34 d outages between cycles.

Number in parentheses are powers of ten, e.g., $1.45(13)=$ $1.45 \times 10^{13}$. 
Table 12.2-2. Radiation Monitoring Equipment Data Area Monitors. (sheet 1 of 7)

\begin{tabular}{|c|c|c|c|c|c|c|c|c|}
\hline $\begin{array}{l}\text { Chamel } \\
\text { number }\end{array}$ & $\begin{array}{l}\text { Chamel } \\
\text { range } \\
(\mathrm{m} / \mathrm{h})\end{array}$ & Chemel function & Chemmel location & $\begin{array}{c}\text { Rote- } \\
\text { meter } \\
\text { location }\end{array}$ & $\begin{array}{c}\text { Detector } \\
\text { iype }\end{array}$ & $\begin{array}{l}\text { Design } \\
\text { beckground } \\
(\pi R / h)\end{array}$ & Alerms & Control function \\
\hline RE-69000A & $\begin{array}{l}1 \times 10^{-1} \\
\text { to } \times 10^{4}\end{array}$ & $\begin{array}{l}\text { Operating floor orea monitor } \\
\text { chamel A. monitors the } \\
550-f t 0-\text { in. level of } \\
\text { area } 405-503\end{array}$ & $\begin{array}{l}\text { Chemel locesed on } \\
\text { the north-east } \\
\text { section of the } \\
\text { mezzenine inslde } \\
\text { containent at the } \\
570-f t 0-\text { in. level }\end{array}$ & $c-131$ & EI Tube & 0.2 & $\begin{array}{l}\text { 1) Circuit fallure } \\
\text { olarm } \\
\text { 2) High-level alarm } \\
\text { 3) High-high-level } \\
\text { alarm }\end{array}$ & $\begin{array}{l}\text { High-high-level alarm } \\
\text { commected in } 2 \text { out of } \\
3 \text { logic for high gomino } \\
\text { evecuation elarm }\end{array}$ \\
\hline RE-69008B & $\begin{array}{l}1 \times 10^{-1} \\
10 \times 10^{6}\end{array}$ & $\begin{array}{l}\text { Operoting floor area monitor } \\
\text { chamet } 8 \text { - monitors the } \\
550-10 \text { - In. level of } \\
\text { area } 405-501\end{array}$ & $\begin{array}{l}\text { Chamel loceted on } \\
\text { the south sestion of } \\
\text { the mezzanine inside } \\
\text { containment st the } \\
570-f t 0 \text {-in. level }\end{array}$ & $c-131$ & en rube & 0.2 & $\begin{array}{l}\text { 1) Circuit follure } \\
\text { alarm } \\
\text { 2) High-level alarm } \\
\text { 3) High-high-level } \\
\text { alarm }\end{array}$ & $\begin{array}{l}\text { High-high-level alarm } \\
\text { connected in } 2 \text { out of } \\
3 \text { logic for high gaine } \\
\text { evecuation elerm }\end{array}$ \\
\hline RE-69008C & $\begin{array}{l}1 \times 10^{-1} \\
\text { to } \\
1 \times 10^{6}\end{array}$ & $\begin{array}{l}\text { Operating floor area monitor } \\
\text { chamel c - monitors the } \\
550-1 t 0-\text { in. level of } \\
\text { area } 405-502\end{array}$ & $\begin{array}{l}\text { Chemnel located on } \\
\text { the west section of } \\
\text { the mezzenine inside } \\
\text { contaiment at the } \\
570-\text { ft } 0 \text {-in. level }\end{array}$ & C-131 & en Tube & 0.2 & $\begin{array}{l}\text { 1) Circuit fallure } \\
\text { alarm } \\
\text { 2) High-level olarm } \\
\text { 3) High-high-level } \\
\text { alarm }\end{array}$ & $\begin{array}{l}\text { High-high-level alarm } \\
\text { connected in } 2 \text { out of } \\
3 \text { logic for high gemma } \\
\text { evecuation alarm }\end{array}$ \\
\hline RE-69009n & $\begin{array}{l}1 \times 10^{-1} \\
1 \times 10^{6}\end{array}$ & $\begin{array}{l}\text { Reactor heed compartment } \\
\text { area monitor chamel A- } \\
\text { monitors the reactor heed } \\
\text { compartiment, area } 405.524\end{array}$ & $\begin{array}{l}\text { Chamel mounted on } \\
\text { the west wall of the } \\
\text { head comportment }\end{array}$ & $c-131$ & Ex Tube & 2.0 & $\begin{array}{l}\text { 1) Circuit fatlure } \\
\text { olarm } \\
\text { 2) High-level alarm } \\
\text { 3) High-high-tevel } \\
\text { clarm }\end{array}$ & None \\
\hline RE-690098 & $\begin{array}{l}1 \times 10^{-1} \\
1 \times 10^{4}\end{array}$ & $\begin{array}{l}\text { Resctor heed compartment } \\
\text { area monitor chamel B - } \\
\text { monitors the reactor heed } \\
\text { compartment, area } 405.524\end{array}$ & $\begin{array}{l}\text { Channel mounied on } \\
\text { the east wol: of the } \\
\text { head compartient }\end{array}$ & C-131 & En Tube & 2.0 & $\begin{array}{l}\text { 1) Circuit fatlure } \\
\text { alarm } \\
\text { 2) High-level alarm } \\
\text { 3) High-high-level } \\
\text { alarm }\end{array}$ & None \\
\hline RE-69009C & $\begin{array}{l}1 \times 10^{-1} \\
10 \times 10^{4}\end{array}$ & $\begin{array}{l}\text { Reactor heed comportment } \\
\text { area monitor chamel C. } \\
\text { monitors the reactor heed } \\
\text { compartment, area } 405-524\end{array}$ & $\begin{array}{l}\text { Charnel mounied on } \\
\text { the south wa.l of the } \\
\text { head compartinent }\end{array}$ & $c-131$ & En Tube & 2.0 & $\begin{array}{l}\text { 1) Circuit failure } \\
\text { olorm } \\
\text { 2) High-level olarm } \\
\text { 3) High-high-level } \\
\text { alarm }\end{array}$ & None \\
\hline $\begin{array}{l}\text { RE-83021 } \\
\text { (Future) }\end{array}$ & $\begin{array}{l}1 \times 10^{-1} \\
\text { to } 1 \times 10^{6}\end{array}$ & $\begin{array}{l}\text { Area monltor - monltors CLS } \\
\text { Loops } 3 \text { and } 4 \text { inert gas } \\
\text { valve operat ing area, } \\
\text { area } 405-5378\end{array}$ & $\begin{array}{l}\text { Detector wounted in } \\
\text { valve op area on } \\
\text { containment vessel } \\
\text { wall near stair } R-10\end{array}$ & $c-131$ & Gil Tube & 2.0 & $\begin{array}{l}\text { 1) Circuit faflure } \\
\text { darm } \\
\text { 2) High-level olarm } \\
\text { 3) High-high-level } \\
\text { larm }\end{array}$ & None \\
\hline
\end{tabular}


Table 12.2-2. Radiation Monitoring Equipment Data Area Monitors. (sheet 2 of 7)

\begin{tabular}{|c|c|c|c|c|c|c|c|c|}
\hline $\begin{array}{l}\text { Charmel } \\
\text { number }\end{array}$ & $\begin{array}{l}\text { Chornel } \\
\text { ronge } \\
(m R / h)\end{array}$ & Charmel function & Chermel location & $\begin{array}{c}\text { Rate- } \\
\text { meter } \\
\text { location }\end{array}$ & $\begin{array}{c}\text { Detector } \\
\text { type }\end{array}$ & $\begin{array}{c}\text { Design } \\
\text { beckground } \\
(\mathrm{mR} / \mathrm{h})\end{array}$ & Alarms & Control function \\
\hline RE-83022 & $\begin{array}{l}1 \times 10^{-1} \\
10 \times 10^{4}\end{array}$ & $\begin{array}{l}\text { Aree monitor - monitors HTS } \\
\text { loop } 3 \text { inert gas valve } \\
\text { operating area, } \\
\text { orea } 405.5548\end{array}$ & $\begin{array}{l}\text { Detector mounted in } \\
\text { valve op orea on } \\
\text { contaiment vessel } \\
\text { wall near stair R-11 }\end{array}$ & C-131 & an rube & 2.0 & $\begin{array}{l}\text { 1) Circuit fallure } \\
\text { olarm } \\
\text { 2) High-level olarm } \\
\text { 3) High-high-level } \\
\text { alarm }\end{array}$ & None \\
\hline RE-96100A & $\begin{array}{l}1 \times 10^{-1} \\
10 \times 10^{4}\end{array}$ & $\begin{array}{l}\text { Aree monitor - monitors } \\
\text { operat ing floor area outs ide } \\
\text { equipment airlock. } \\
\text { ores } 4717-258\end{array}$ & $\begin{array}{l}\text { Chamel mounted on } \\
\text { onter surface of CB } \\
\text { wall }\end{array}$ & $c-131$ & On rube & 0.2 & $\begin{array}{l}\text { 1) Circuit failure } \\
\text { alarm } \\
\text { 2) High-level alarm } \\
\text { 3) High-high-level } \\
\text { alarm }\end{array}$ & $\begin{array}{l}\text { High-high-level olarm } \\
\text { comnected in } 2 \text { out of } \\
3 \text { logic for high gorma } \\
\text { evecuation olorm } \\
\text { system }\end{array}$ \\
\hline RE-96100B & $\begin{array}{l}1 \times 10^{-1} \\
10 \times 10^{6}\end{array}$ & $\begin{array}{l}\text { Area monit tor - monit tors } \\
\text { inside equipment oirlock, } \\
\text { area } 405-505\end{array}$ & $\begin{array}{l}\text { Chamnel mounted } \\
\text { inside oirlock }\end{array}$ & $c-131$ & on tube & 0.2 & $\begin{array}{l}\text { 1) Circuit failure } \\
\text { olarm } \\
\text { 2) High-level olorm } \\
\text { 3) High-high-level } \\
\text { Olarm }\end{array}$ & $\begin{array}{l}\text { High-high- level olorm } \\
\text { comected in } 2 \text { out of } \\
3 \text { logic for high germm } \\
\text { evecuation olorm } \\
\text { systen }\end{array}$ \\
\hline RE-96100C & $\begin{array}{l}1 \times 10^{-1} \\
10 \times 10^{4}\end{array}$ & $\begin{array}{l}\text { Area monitor - monitors } \\
\text { operat ing floor area outside } \\
\text { equipment afrlock, } \\
\text { area } 4717-258\end{array}$ & $\begin{array}{l}\text { Ctamel mounted on } \\
\text { outer surface of } \\
\text { AEB-W wall }\end{array}$ & c-131 & On Tube & 0.2 & $\begin{array}{l}\text { 1) Circuit foilure } \\
\text { olorm } \\
\text { 2) High-level olarm } \\
\text { 3) High-high-level } \\
\text { alorm }\end{array}$ & $\begin{array}{l}\text { High-high-level olorm } \\
\text { comnected in } 2 \text { out of } \\
3 \text { logic for high gemme } \\
\text { evecuation olarm } \\
\text { systen }\end{array}$ \\
\hline$R E-83007$ & $\begin{array}{l}1 \times 10^{-1} \\
\text { to } \\
1 \times 10^{4}\end{array}$ & $\begin{array}{l}\text { Ares monitor - monitors gas } \\
\text { sempl ing access area WTS-S, } \\
\text { ores } 4915-481\end{array}$ & $\begin{array}{l}\text { Chonnel mounted on } \\
\text { north wall of occess } \\
\text { area }\end{array}$ & $c-131$ & on Tube & 2.0 & $\begin{array}{l}\text { 1) Circuit failure } \\
\text { olorm } \\
\text { 2) High-level alarm } \\
\text { 3) High-high-level } \\
\text { alarm }\end{array}$ & Mone \\
\hline RE-83008 & $\begin{array}{l}1 \times 10^{-1} \\
\text { to } \\
1 \times 10^{4}\end{array}$ & $\begin{array}{l}\text { Area monitor - monitors the } \\
\text { access and operating erea on } \\
\text { the } 537-f t \text { - in . level of } \\
\text { RSB, ores } 4717-264\end{array}$ & $\begin{array}{l}\text { Chamel mounted on } \\
\text { west side of center } \\
\text { support column }\end{array}$ & c-131 & an Tube & 0.2 & $\begin{array}{l}\text { 1) Circuit faflure } \\
\text { olarm } \\
\text { 2) High-level olorm } \\
\text { 3) High-high-level } \\
\text { alam }\end{array}$ & Mone \\
\hline RE-83009 & $\begin{array}{l}1 \times 10^{-1} \\
\text { to } \\
1 \times 10^{6}\end{array}$ & $\begin{array}{l}\text { Area monitor - monitors the } \\
\text { occess and operating orea on } \\
\text { the 522-ft 6-in. level of } \\
\text { the RSB, aree 4717-224 }\end{array}$ & $\begin{array}{l}\text { Channel mounted on } \\
\text { the west side of the } \\
\text { center support colum }\end{array}$ & C-131 & on rube & 0.2 & $\begin{array}{l}\text { 1) Circuit follure } \\
\text { alom } \\
\text { 2) Migh-level alarm } \\
\text { 3) Migh-high-level } \\
\text { olarm }\end{array}$ & Mone \\
\hline
\end{tabular}


Table 12.2-2. Radiation Monitoring Equipment Data Area Monitors. (sheet 3 of 7)

\begin{tabular}{|c|c|c|c|c|c|c|c|c|}
\hline $\begin{array}{l}\text { Chamel } \\
\text { number }\end{array}$ & $\begin{array}{l}\text { Channel } \\
\text { range } \\
(\mathrm{mR} / \mathrm{h})\end{array}$ & Channel function & Chamel Iscation & $\begin{array}{l}\text { Rate- } \\
\text { meter } \\
\text { location }\end{array}$ & $\begin{array}{c}\text { Detector } \\
\text { type }\end{array}$ & $\begin{array}{c}\text { Design } \\
\text { beckground } \\
(\mathrm{mR} / \mathrm{h})\end{array}$ & Alarms & Control function \\
\hline RE- 83010 & $\begin{array}{l}1 \times 10^{-1} \\
1 \times 10^{4}\end{array}$ & $\begin{array}{l}\text { Ares monitor - monitors the } \\
\text { access area on the } 508-\mathrm{ft} \\
0-\text { in. level of the RSB, } \\
\text { area } 4717-212\end{array}$ & $\begin{array}{l}\text { Channel mourted on } \\
\text { the west sice of the } \\
\text { center suppert column }\end{array}$ & $c-131$ & GN Tube & 0.2 & $\begin{array}{l}\text { 1) Circuit failure } \\
\text { olarm } \\
\text { 2) High-level olarm } \\
\text { 3) High-high-level } \\
\text { olarm }\end{array}$ & Mone \\
\hline RE-83011 & $\begin{array}{l}1 \times 10^{-1} \\
10 \times 10^{4}\end{array}$ & $\begin{array}{l}\text { Aree monitar - monitors } \\
\text { elevetion } 532-\mathrm{ft} 5 \text {-in. of } \\
\text { the IEM cell operating area, } \\
\text { area } 405-520\end{array}$ & $\begin{array}{l}\text { Channel mourted on } \\
\text { the inner cont binment } \\
\text { vessel wall west of } \\
\text { stairwell }\end{array}$ & $c \cdot 131$ & GM Tube & 1.0 & $\begin{array}{l}\text { 1) Circuit failure } \\
\text { alarm } \\
\text { 2) High-level alarm } \\
\text { 3) High-high-level } \\
\text { olarm }\end{array}$ & Mone \\
\hline RE-83012 & $\begin{array}{l}1 \times 10^{-1} \\
10 \times 10^{4}\end{array}$ & $\begin{array}{l}\text { Area monitar - monitors HTS } \\
\text { loop } 2 \text { inert gas valve } \\
\text { operat ing area, } \\
\text { orea 405-5538 }\end{array}$ & $\begin{array}{l}\text { Detector mounted in } \\
\text { valve Op area on } \\
\text { containment vessel } \\
\text { wall - local } \\
\text { indication and al arm } \\
\text { module located near } \\
\text { stair numer R-9 }\end{array}$ & $c-131$ & GN Tube & 2.0 & $\begin{array}{l}\text { 1) Circuit failure } \\
\text { alarm } \\
\text { 2) High-level alarm } \\
\text { 3) High-high-level } \\
\text { alarm }\end{array}$ & Hone \\
\hline$R E-83013$ & $\begin{array}{l}1 \times 10^{-1} \\
\text { to } \\
1 \times 10^{4}\end{array}$ & $\begin{array}{l}\text { Area monitor - monitors } \\
\text { elevation } 516-\mathrm{ft} 0-\mathrm{in} \text {. of } \\
\text { the IEN cell operating area, } \\
\text { orea } 405-550\end{array}$ & $\begin{array}{l}\text { Channel nourted on } \\
\text { inner containment } \\
\text { vessel wall west of } \\
\text { stairwell }\end{array}$ & $c-131$ & GN Tube & 1.0 & $\begin{array}{l}\text { 1) Circuit failure } \\
\text { olorm } \\
\text { 2) High-level olarm } \\
\text { 3) High-high-level } \\
\text { olarm }\end{array}$ & None \\
\hline RE -83001 & $\begin{array}{l}1 \times 10^{-1} \\
\text { to } \\
1 \times 10^{4}\end{array}$ & $\begin{array}{l}\text { Area monitor - monitors } \\
\text { personnel airlock area } \\
\text { inside containment, } \\
\text { orea } 405-500\end{array}$ & $\begin{array}{l}\text { Channel moumted on } \\
\text { west side of column } \\
\text { number } 2 \text { inside } \\
\text { containment }\end{array}$ & $c-131$ & GN Tube & 0.2 & $\begin{array}{l}\text { 1) Circuit failure } \\
\text { alarm } \\
\text { 2) High-level alarm } \\
\text { 3) High-high-level } \\
\text { alarm }\end{array}$ & Mone \\
\hline$R E-83002$ & $\begin{array}{l}1 \times 10^{-1} \\
\text { to } \\
1 \times 10^{4}\end{array}$ & $\begin{array}{l}\text { Area monitor - monitors HTS } \\
\text { loop } 1 \text { inert gas valve } \\
\text { operating area, } \\
\text { area } 405-5528\end{array}$ & $\begin{array}{l}\text { Detector mounted in } \\
\text { valve op ores on } \\
\text { containment vessel } \\
\text { wall - locel } \\
\text { indication and at arm } \\
\text { nodule loceted in } \\
\text { access area } 405-563 \\
\text { near stair } \\
\text { number R-12 }\end{array}$ & $c-131$ & Gin Tube & 2.0 & $\begin{array}{l}\text { 1) Circuit failure } \\
\text { olorm } \\
\text { 2) High-level alarm } \\
\text { 3) High-high-level } \\
\text { olarm }\end{array}$ & Wone \\
\hline
\end{tabular}




\subsection{REFERENCES}

1. Waste Management Manual, HEDL-TMT-3.

2. Seismic Design Criteria for the Fast Flux Text Facility Site, JABE-WADCO-02, July 1972.

3. A. Court, Analysis of Sealing Effectiveness of FFTF Head Compartment Components, WARD-2171-53, May 1975.

4. International Commission on Radiological Protection, Publication 2 (1959), Pergamon Press, Oxford.

5. J. D. Anderson, Specifications and Standards for the Packaging, Storage and Disposal of Richland Operations Office Solid Wastes, ARH-3032, April 1974.

6. "Safety Standards for the Packaging of Fissile and other Radioactive Materials," ERDA Manual, Chapter 0529, and the RL Manual, Chapter Supplement, May 1975.

7. "Nuclear Criticality Safety, " ERDA Manual, Chapter 0530, and the RL Manual, Chapter Supplement.

8. "Effluent and Environmental Reporting," ERDA Manual, Chapter 0513, and the RL Manual, Chapter Supplement.

9. Radiation Protection Procedures, WHAN-M-8.

10. Jack J. Fix, Environmental Surveillance at Hanford for FY-1974, BNWL-1910.

11. Federal Radiation Council, Staff Reports No. 1 (1960), No. 2 (1961), No. 5 (1964) and No. 7 (1965), Background Material for the Development of Radiation Protection Standards, Superintendent of Documents, Washington.

12. Maximum Permissible Body Burdens and Maximum Permissible Concentrations of Radionuclides in Air and Water for Occupational Exposure" Report No. 22, 1963, and "Basic Radiation Protection Criteria" Report No. 39, 1971, National Council on Radiation Protection and Measurements Publications, Washington. 
13. R. H. Wilson, and T. H. Essig, Criteria Used to Estimate Radiation Doses Received by Persons Living in the Vicinity of Hanford: Interim Report, BNWL-706, July 1968.

14. T. H. Essig and J. P. Corley, Criteria Used to Estimate Radiation Doses Received by Persons Living in the Vicinity of Hanford: Interim Report No. 2, BNWL-1019, April 1969.

15. C. B. Wilson and T. H. Essig, Editors, Evaluation of Radiological Conditions in the Vicinity of Hanford for 1969, BNWL-1505, November 1970.

16. Radiological Design Criteria, WHAN-M-7.

17. Criticality Safety Procedures, WHAN-M-6.

18. Environmental Impact Statement - Liquid Metal Fast Breeder Reactor Demonstration Plant, WASH-1590, (1535 Vol. 3).

19. Operational Health Physics Procedures, HEOL-TME, 72-20.

20. FFTF Shield Design Criteria, WHAN-IR-49.

21. Portable Radiation Survey Manual, BNWL-MA-62.

22. The Hanford Thermoluminescence Multipurpose Dosimeter, BNWL-SA-3955.

23. Thermoluminescence Personnel Dosimetry at Hanford, BNWL-SA-2793.

24. Deleted

25. Environmental Statement - Fast Flux Test Facility, Richland, Washington, WASH 1510, May 1972.

26. Kebele, T. J., "Estimates of Tritium Distribution in the FFTF," HEDL-TME 74-6.

27. Bahtia, S. L., "Justification for ruel llandling and Storage at rrTr without a Criticality A7 arm System, "WHC-SD-SQA-CSA-20303, Westinghouse Hanford Company, Richland, Washington, April 20, 1990. 
CHAPTER 13.0

CONDUCT OF OPERATIONS

CONTENTS

Page

13.0 ORGANIZATION STRUCTURE

13.1-1

13.1.1 WESTINGHOUSE HANFORD COMPANY ORGANIZATION

$13.1-1$

13.1.1.1 Westinghouse Hanford Company

Responsibilities and Authorities 13.1-1

13.1.1.2 Technical Staff

$13.1-2$

13.1.1.2.1 Advanced Reactor Development

Division

13.1-2

13.1.1.2.2 Engineering 13.1-3

13.1.1.2.3 Quality Assurance 13.1-3

13.1.1.2.4 Safety 13.1-5

13.1.1.2.5 Safeguards and Security 13.1-7

13.1.1.2.6 Emergency Preparedness 13.1-8

13.1.1.2.7 Environmental Division 13.1-8

13.1.1.2.8 Safety and Environmental Advisory
Council

13.1.2 FAST FLUX TEST FACILITY PLANT ORGANIZATION 13.1-9

13.1.2.1 Personnel Responsibilities and Authorities 13.1-9

13.1.2.1.1 Fast Flux Test Facility Plant Manager 13.1-9

13.1.2.1.2 Fast Flux Test Facility Engineering Manager

$13.1=9$

13.1.2.1.3 Fast Flux Test Facility Operations Manager

13.1-11

13.1.2.1.3.1 Fast Flux Test Facility Shift Operations Crews

13.1.2.1.3.2 Examination and Decontamination

13.1-11

Services Operations Manager

13.1-14

13.1.2.1.3.3 Fast Flux Test Facility Operations Support Organization

13.1.2.1.3.4 Succession of Fast flux Test

Facility Operations Authority

13.1-15

13.1-16

13.1.2.1.4 Fast Flux Test Facility Core Engineering 13.1-17

13.1.2.1.5 Fast Flux Test Facility Work Control 13.1-18

13.1.2.1.6 Fast Flux Test Facility Special

Projects and Administration

13.1-18 
13.1.2.2 Plant Organization Shift Crew Composition

$13.1-19$

13.1.2.2.1 Shift Operations Crews

13.1-19

13.1.2.2.2 Shift Maintenance Crews

$13.1-20$

13.1.2.2.3 Operational Health Physics

$13.1-21$

13.1.3 WESTINGHOUSE HANFORD COMPANY ORGANIZATIONS

SUPPORTING FAST FLUX TEST FACILITY ACTIVITIES

13.1-21

13.1.3.1 Safety, Quality Assurance, and Security

$13.1-21$

13.1.3.1.1 Safety

13.1.3.1.2 Quality Assurance

13.1-21

$13.1-22$

13.1.3.1.2.1 Engineering and Development

13.1.3.1.2.2 Engineering and Development

$13.1-22$

Division Quality Control

$13.1-22$

13.1.3.2 Operations Support Services Department

$13.1-22$

13.1.3.2.1 400 Area Support Services

13.1.3.2.2 Technical Training

13.1-22

$13.1-23$

13.1.3.2.2.1 400 Area Training

$13.1-23$

13.1.3.2.2.2 Maintenance Training

$13.1-24$

13.1.3.2.2.3 Safety Training

13.1.3.2.2.4 Computer-Based Training

$13.1-24$

$13.1-25$

$13,1,4$ QUALIFICATION REQUIREMENTS FOR FAST FLUX TEST

FACILITY PLANT OPERATING PERSONNEL

$13.1=25$

13.1.4.1 Scope

13.1.4.2 Definitions

13.1-25

$13.1-25$

13.1.4.3 Qualification Requirements

$13.1-27$

13.1.4.3.1 General

$13.1-27$

13.1.4.3.2 Certification of Operating Personnel

13.1.4.3.3 Exceptions

$13.1-27$

13.1-28

13.1.4.4 Training Requirements

13.1-28

13.1.4.4.1 Ceneral Employec Training

13.1.4.4.2 Training for Managers and Supervisors

13.1.4.4.3 Training for Professional/Technical

Personnel

$13.1-28$

$13.1-28$

$13.1-29$

13.1.4.4.4 Training for Technicians and Maintenance Personnel

$13.1-29$ 


\subsection{FFTF Operations Manager}

The FFTF Operations Manager is directly responsible to the FFTF Plant Manager and has the following responsibilities:

- Safe and efficient operation of the FFTF

- Technical Specifications compliance

- Occurrence Reporting

- Operating procedures system

- Refueling

- 400 Area Assistant Emergency Director

- FFTF inventory control

- IEM cell operation

- Decontamination services at the FFTF

- Operational planning for the MASF

- MASF operation

- Criticality safety

- Hazardous and Radioactive Waste Handling and Disposition.

\subsection{FFTF Shift Operations Crews}

An FFTF Shift Operations Manager is in charge of each crew and exercises overall control of a team composed of skilled and proficient personnel. There are 5 shift operations crews to operate the plant continuously ( $24 \mathrm{~h} / \mathrm{day}$, 7 day/week). The shift operations crews are directly responsible for safe and efficient operation of the plant and its supporting facilities. 
Typical shift operations crew assignments are made by the watchstations, which are divided between the Control Room watchstations and ex-Control Room watchstations. A list of shift operations watchstations and the number of watchstanders is shown in Table 13.1-1. Minimum manning is defined in FSAR Chapter 17, "Technical Specifications." In addition, operator trainees are normally assigned to each crew. During reactor operations, personnel on watch are directly supervised by a Chief Operator $(\mathrm{CO})$ in the Control Room. During refueling operations, operating personnel involved with the refueling are directly supervised by the Refueling Engineer; all other watchstations report to the Control Room Shutdown Operator.

The shift operations personnel can be functionally categorized as management/supervisory personne] [Shift Operations Manager (SOM), Assistant Shift Manager], technical supervisory or lead personnel [Operations Engineer (OE), Chief Operator, Refueling Engineer], Control Room technical personnel [Reactor Operator (RO), Dump Heat Exchanger (DHX) Operator, etc.], and ExControl Room technician personnel (Watchstanders and Refuelers). Responsibilities and authorities are detailed below.

Shift Operations Manager -- The SOM (Figure 13.1-4) is responsible, under direction of the FFTF Operations Manager, for overail plant and fuel handling operations on the assigned shift. The SOM provides direction and performs management review of ongoing operations. The SOM maintains the broadest perspective of operational conditions affecting the safety of the plant at all times. The SOM functions as the senior Westinghouse Hanford management representative at the FFTF site whenever higher line managers are absent from the site. In this capacity, the SOM initiates and directs emergency response and recovery actions. The SOM may consult with available technical advisors, as necessary, but retains full responsibility and authority for plant and refueling operations.

In case of an unscheduled or unexplained power reduction or an automatic reactor shutdown, the SOM has responsibility for determining the circumstances, analyzing the cause, and reporting to senior management, including the FFTF Plant Manager. The FFTF Plant Manager is ultimately responsible for the decision to restart or restore the reactor to power. 
- Certify EDS technicans

- Resolve IEM cell and MASF operational problems

- Coordinate rotating shift activities and prepare shift instructions

- Perform decontamination services at the FFTF

- Maintain operational cognizance of MASF equipment and systems operation

- Manage the IEM cell and MASF staff.

\subsection{FFTF Operations Support Organization}

The FFTF Operations Manager has a support organization that is responsible for the following activities:

- Prepare, review, process for approval, and maintain distribution of new or revised Operations administrative and operating procedures

- Coordinate the Technical Specification compliance program. This includes maintenance of the Technical Specifications administrative procedure to ensure compliance and reporting of any noncompliance occurrences

- Perform plant and system problem analysis as directed by the FFTF Operations Manager

- Maintain plant logs and records

- Maintain adequate consumables and supplies

- Coordinate input to and maintain the Operations and Test Plan (OTP) and the Experimental Run Plan (ERP) for each operating cycle

- Control the criticality safety program at the FFTF

- Maintain the FFTF Occurrence Management System 
- Coordinate the Environmental Surveillance compliance program

- Coordinate the handling and accountability of radioactive waste

- Administer the ALARA program as supplied to waste handling

- Monitor the control of plant argon, nitrogen, sodium, and chemistry

- Maintain the Human Performance Enhancement System (HPES)

- Coordinate the handling and disposition of hazardous and radioactive waste.

\subsection{Succession of FFTF Operations Authority}

The Assistant Operations Manager normally acts for the FFTF Operations Manager during periods when the latter is not available to perform normal duties. If the Assistant Operations Manager is not available, the FFTF Operations Manager may appoint an SOM to act.

During an unplanned absence of the SOM, the Assistant Shift Manager acts as a replacement. If neither the SOM nor the Assistant Shift Manager is present, the Operations Manager appoints, in writinq, an individual to assume the SOM responsibilities. The appointed individual must be a qualified $O E$. In the event that the SOM is unable to delegate responsibility (because of sudden illness, etc.), the Assistant Shift Manager immediately assumes the responsibilities of the SOM. If an emergency causes the absence of all other OE-qualified personnel, the Assistant Shift Manager assumes the duties of CO. If, as a result of the absence of all OEs other than the SOM, the SOM believes continued operation is imprudent, the SOM shall proceed immediately with established plant shutdown procedures.

If the $\mathrm{CO}$ is suddenly unable to stand the watchstation, the Reactor Operator shall immediately assume the additional CO responsibilities until another $O E$ can assume the $\mathrm{CO}$ watchstation. 


\section{K. Inert Gas Accidents}

Accidents involving accidental releases of inert gas would fall into the "Unusual Event" category. Installed oxygen monitors will alert personnel to the problem. Administrative Procedure A-18, "Entry into Inert or Potentially Inert Spaces, "(12) governs personnel working in inerted spaces. Portable oxygen monitors will be required for entry into certain areas of the plant.

\subsection{Instrumentation Capability for Detection}

The instrumentation capability for prompt detection and continued assessment of the accidents hypothesized for the FFTF involving release of radioactivity is provided by the System 96 area radiation monitors, effluent air monitors, and the containment isolation system radiation monitors. In the event of high radiation levels resulting from one of the hypothesized accidents, the radiation monitoring system will initiate alarm signals locally, in the Control Room, or both, when radiation levels exceed preset limits. A summary of this equipment as it relates to the accidents presented previously is shown in Table 13.3-4.

The area radiation monitoring subsystem continuously monitors the radiation status of the $p l a n t$. A typical detector station consists of a radiation detector (halogen-quenched Geiger Mueller [GM] tube), a preamplifier, a solenoid-operated check source, audible and visual alarms, and a radiationlevel indicator. Associated electronics, located in the Control Room, included a logarithmic ratemeter and indicator, a high and a high-high radiation comparator, a loss-of-signal comparator, calibration and maintenance circuitry, power supply, input to the Plant Data System (PDS), and inputs to the annunciator in the Control Room. Six of the monitors are connected to two sets of two-out-of-three logic and serve to initiate an evacuation alarm when the gamma levels exceed preestablished limits. The logic network provides redundancy while minimizing spurious trips. In addition, five ex-containment area monitors can serve a postaccident monitoring function for providing an indication of the 
in-containment radiation field, should an event release sufficient radioactive material to exceed the range of the in-containment monitors. Three ratemeters have a five-decade range from $10^{-1} \mathrm{mR} / \mathrm{h}$ to $10^{4} \mathrm{mR} / \mathrm{h}$, and two ratemeters have a range from $1 \mathrm{mR} / \mathrm{h}$ to $10^{7} \mathrm{mR} / \mathrm{h}$. The design is such that the response time over the entire range of the operation is tailored to provide both stability and speed of response. The ratemeter is required to withstand radiation fields equivalent to one decade above full scale without foldover. Area radiation monitor detectors are located in approximately 34 locations in the Plant. For tabulation of detector locations see Table 12.2-2 or SDD-96, Table 2-1. (14) Each detector station has local audible and visual alarms and a radiation level indicator. The ratemeters for the area monitors are located in Panel C-131 in the Control Room, and separate annunciation is provided on Panel C-136 in the Control Room. Signals are monitored by comparators that actuate alarms in the radiation zone and in the Control Room. The signals are also recorded by the PDS once per minute. In the event of a release of a large amount of radioactive material within the containment structure, all of the area radiation monitors will provide redundant confirmation of high radiation levels. For the case of a release large enough to exceed the range of the in-containment monitors, such as the HCDA, the postaccident monitors located outside the containment structure will provide an indication of radiation levels.

The containment isolation monitors will also provide detection capability in the event of certain accidents. These detectors monitor the radiation level in containment above the operating floor and the radiation levels of gaseous and airborne activity before it leaves containment. The detectors will automatically close all containment isolation valves or heating and ventilation (H\&V) system discharge valves, depending on activity level, with sufficient lead time to limit releases to the environment. Differences that are significant include the fact that no visual or audible alarms are required at the detector station and that the foldover and response time requirements are more stringent. 
with all abnormal operating conditions. This could include isolation of subsystems or complete plant shutdown.

Extensive provision is also made for monitoring radioactivity throughout the Plant. Systems described in Section 13.3.7.3 for this purpose and portable instrumentation is located in the Plant adequately to allow for decision making by trained $P l$ ant personnel. Any significant, unexplained increase or alarm in $\mathrm{Plant}$ or effluent radiation monitoring instrumentation is the action level for some protective measures. This may mean evacuation from local areas of the Plant, one or more buildings, or complete Plant evacuation, depending on the classification of the emergency. Automatic evacuation of the Reactor Containment Building and/or the Reactor Service Building occurs whenever the High Gamma Evacuation Alarm System is tripped in either or both of these areas.

\section{Notification}

The Communication System described in Section 13.3.7.2 provides the means to notify involved personnel of what protective actions are required. The time required for notification is on the order of a few minutes for Plant personnel, using the combination public address/evacuation siren system. Only slightly longer will be required to notify the WPPSS by telephone or radin.

\section{Access Control}

Because of the FFTF location within the Hanford Site, access control to the FFTF is readily available by notification to the Hanford Patrol. The Patrol can isolate whatever area, as necessary, by barricade of a limited number of highways on the Hanford Site. All communications for this service are through the assigned Patrol Emergency officer (PEO), who is on duty at all times. 


\section{Evacuation and Reassembly}

Upon direction of the FFTF ED, all facility personnel, visitors, and contractor personnel (other than the shift operating crew) will evacuate facility areas and proceed to the FFTF Staging Area. The emergency procedures will provide detailed evacuation information, including prohibitions against taking indirect evacuation routes to retrieve personal effects or outer clothing. At this point, procedures and equipment are provided to determine whether the Staging Area is a habitable area and to perform personnel accountability. Preliminary surveys will also be made to determine the contamination/exposure status of people involved and any necessary decontamination to be started.

The FFTF Staging Area will normally be the center for all protective actions during emergencies.

In the event that the Staging Area is not habitable, all personnel (other than the operating crew on shift) will evacuate to the alternate FFTF Staging Area (specified in the emergency procedures) or other location determined by the 300/400 Area Emergency Director.

Private automobiles of the evacuees in the habitable staging area will be used to leave the staging area. Additional vehicles can be obtained from Westinghouse Hanford Transportation Services, if required. If contaminated or potentially contaminated vehicles are used for evacuation, all evacuation vehicles will be directed by the Patrol to the 300 Area South Parking Lot. The Patrol will impound the vehicles until they are surveyed by Radiation Monitors. Contaminated vehicles will be held for decontamination or other disposition.

If inclement weather or other conditions make occupancy of the Staging Area inadvisable, evacuation will be to the 300 Area South Parking Lot Staging Area where Westinghouse Hanford ERO personnel will direct the evacuees to a sheltered area for monitoring and 
- Ring-down telephone circuit, which has an exclusive direct connection to the Westinghouse Hanford ECC

- General Plant telephone, which is connected throughout the Hanford Site and offsite through the Richland exchange

- Radio, which is a mobile unit in the FFTF ECC with the same frequency as Patrol.

These systems are supplemented by vehicle radio units, walkie-talkie equipment, and messengers.

For situations that arise at times other than normal working hours, a residential crash alarm telephone system can be used to report an emergency condition. This system operates in the same way as the Hanford Site crash al arm telephones, but it is connected to residences of selected DOE-RL contractor personnel in Richland and is activated by the PEO in the Federal Building:

\section{A. Fire Detection and Alarm}

Fire protection systems are located throughout the FFTF complex. These syslems delect and/or extinguish fires while alerting building occupants by sounding a gong. The systems also provide a coded signal to the 300 Area Fire Station.

In addition to the preceding functions, an annunciator in the Control Room is activated. Fire detectors in areas that are vital to FFTF operating continuity will activate specific area annunciators in the Control Room. Instructions to evacuate areas and zones (or take other actions), in addition to evacuating the immediate vicinity of the local alarm, can then be transmitted over the public address system and/or the FFTF $P$ lant telephone system. On receipt of the fire alarm signal by the Hanford Fire Department, the PEO is notified by emergency telephone or by radio. The PEO notifies selected representatives of Westinghouse Hanford management, DOE management, and management of other 
Hanford Site contractors. During normal working hours, notification is by Plant telephone system using emergency call lists. At other hours, the notification may be by using call lists or by the residential crash alarm system via the commercial telephone system in Richland. The PEO at the Federal Building activates the system, which simultaneously rings residential phones of selected contractor personnel (including Westinghouse Hanford representatives) in Richland. During regular work hours, the first available manager on the Westinghouse Hanford call list will be notified by the PEO by Plant telephone. The manager contacted will provide appropriate additional notifications within Westinghouse Hanford. This can be accomplished by directing the 300 Area Patrol Radio Room Operator to activate the Crash Alarm System and pass along a specific message.

\section{B. High Radiation Monitor and Alarm}

Work locations where significant quantities of fissionable materials are stored or handled can present a radiation hazard. Such locations are equipped with radiation-sensitive detectors that provide alarms in the work location if high radiation is detected and annunciated in the Control Room. The RCB and the RSB operating floors (550-ft level) are provided with radiation-sensitive detectors that will initiate an automatic evacuation of these areas by activating the High Gamma Alarm System. A complete description of radiation monitors at the FFTF is included in SDD.96. ${ }^{(14)}$

\section{Evacuation}

An automatic personnel evacuation of the RCB and/or RSB is initiated whenever the High Gamma System alarms are tripped in either or both of these areas.

A signal is transmitted to FFTF personnel by a steady siren for a plant evacuation over the public address system when manually actuated from the Control Room as authorized by the FFTF ED. 
Chapter 16.0

QUALITY ASSURANCE

CONTENTS

Page

16.1.1 INTRODUCTION

16.1.1-1

16.1.1.1 PURPOSE

16.1.1-1

16.1.1.2 APPLICABILITY

16.1.1.3 PURCHASER (OWNER) ACTIONS

$16.1 .1-1$

16.1.1-2

16.2.1 ORGANIZATION

16.2.1-1

16.2.1.1 RESPONSIBILITY AND AUTHORITY

16.2.1-1

16.2.2 QUALITY ASSURANCE PROGRAM

16.2.2-1

16.2.2.1 PLANNING

16.2.2.2 IMPLEMENTING DOCUMENTS

16.2.2-1

$16.2 \cdot 2-1$

16.2.2.3 TRAINING AND INDOCTRINATION

16.2.2.4 PERSONNEL QUALIFICATION

$16.2 .2-2$

16.2.2.5 MANAGEMENT ASSESSMENT

$16.2 .2-3$

$16.2 .2-4$

16.2.3 DESIGN CONTROL

16.2.3-1

16.2.3.1 RESPONSIBILITY

16.2.3-1

16.2.3.2 DESIGN PLANNING

$16.2 .3-1$

16.2 .3 .3

DESIGN CRITERIA

16.2.3-1

16.2 .3 .4

CODES, STANDARDS, AND PRACTICES

16.2 .3 .5

ENGINEERING STUDIES

16.2 .3 .6

PARTS, MATERIALS, AND PROCESSES

16.2.3.7

DESIGN DESCRIPTIONS

16.2 .3 .8

DESIGN DEFINITION AND CONTROL

16.2 .3 .9

DESIGN REVIEWS

16.2 .3 .10

DESIGN VERIFICATION TESTING

16.2.3-1

16.2.3-2

$16.2 .3-2$

$16.2 .3-2$

$16.2 .3-3$

$16.2 .3-3$

$16.2 .3-4$

16.2.3.10.1 Experiment Design

16.2.3-4

16.2.3.10.1.1 Test Requirements

16.2.3.10.1.2 Test Planning

16.2.3.10.1.3 Procedures

16.2.3.10.1.4 Readiness Reviews

16.2.3.10.1.5 Test Reviews

16.2.3-5

$16 \cdot 2 \cdot 3-5$

$16.2 .3-5$

$16.2 .3-5$

$16.2 .3-6$

16.2.3.10.2 Facility/Equipment Design

$16.2 .3-6$

16.2.3.10.2.1 Test Requirements

$16.2 .3-6$

16.2.3.10.2.2 Test Planning

$16.2 .3-6$

16.2.3.10.2.3

Procedures

16.2.3.10.2.4 Readiness Reviews

$16.2 .3-7$

$16.2 .3-7$

$16.2 .3 \cdot 10.2 .5$ Test Reviews

$16.2 .3-7$ 


\section{CONTENTS (Cont.)}

16.2.3.10.3 Test Items

Page

16.2.3.10.4 Test Equipment and Fluids

16.2.3.10.5 Data Acquisition Equipment and Methods

16.2.3.10.6 Failure Analysis

16.2.3.10.7 Test Results

16.2.3.10.8 Test Records

$16.2 .3-7$

$16.2 .3-8$

$16.2 .3-8$

$16.2 .3-8$

$16.2 .3-8$

$16.2 .3-8$

16.2.3.11 ITEM QUALIFICATION

$16.2 .3-8$

$16.2 .3-9$

$16.2 .3-9$

16.2.3.13 INTERFACE CONTROL

16.2.3.14 LEVELS OF CONTROL

$16.2 .3-10$

16.2.3.15 QUALITY RECORDS

$16.2 .3-10$

16.2.4 PROCUREMENT DOCUMENT CONTROL

16.2.4-1

16.2.4.1 PROCUREMENT REQUIREMENTS

16.2.4-1

16.2.4.2 PROCUREMENT DOCUMENT REVIEW

$16.2 .4-2$

16.2.5 INSTRUCTIONS, PROCEDURES, AND DRAWINGS

$16.2 .5-1$

16.2.5.1 POLICIES AND PROCEDURES

16.2.5.2 WORK INSTRUCTIONS

16.2.5.3 OPERATING PROCEDURES

16.2.5.4 REFUELING INSTRUCTIONS

16.2.5.5 OPERATION CONTROL

$16.2 .5-1$

$16.2 \cdot 5-2$

16.2.5-3

$16.2 \cdot 5-4$

$16.2 .5-4$

16.2.6 DOCUMENT CONTROL

16.2.6-1

16.2.7 CONTROL OF PURCHASED ITEMS AND SERVICES

$16 \cdot 2 \cdot 7-1$

16.2.8 IDENTIFICATION AND CONTROL OF ITEMS

$16.2 .8-1$

16.2.9 CONTROL OF PROCESSES

16.2.9-1

16.2.9.1 FABRICATION AND ASSEMBLY PROCESSES

16.2.9-1

16.2.9.1.1 Process Qualification

16.2.9-1

16.2.9.1.2 Nondestructive Examination

16.2.9.1.3 Cleaning

$16.2 .9-2$

$16.2 .9-2$

16.2.9.1.4 Other Special Processes

16.2.9-2

16.2.10/11 INSPECTION AND TEST CONTROL

$16.2 .10 / 11-1$

16.2.10/11.1 PLANNING

16.2.10/11.2 INSPECTION AND TEST PLAN

$16.2 .10 / 11-1$

$16.2 .10 / 11-1$

16.2.10/11.3 INSPECTION AND TEST

$16.2 .10 / 11-1$ 


\section{CONTENTS (Cont'd)}

16.2.10/11.3.1 General Requirements

16.2.10/11.3.2 Procedures

16.2.10/11.3.3 Completed Item Inspection and Test

$16.2 .10 / 11-1$

$16.2 .10 / 11-2$

$16.2 .10 / 11-2$

16.2.10/11.4 INSTALLATION INSPECTION

$16.2 .10 / 11-3$

16.2.12 CONTROL OF MEASURING AND TEST EQUIPMENT

$16.2 \cdot 12-1$

16.2.12.1 MEASURING AND TEST EQUIPMENT CALIBRATION AND CONTROL

$16.2 .12-1$

16.2.13 HANDLING, STORAGE, AND SHIPPING

16.2.13-1

16.2.13.1 HANDLING

16.2.13.2 PRESERVATION, PACKAGING, AND STORAGE

16.2.13.3 SHIPPING

16.2.13-1

$16.2 .13-1$

16.2.13-2

16.2.14 INSPECTION, TEST, AND OPERATING STATUS

$16.2 .14-1$

16.2.15 CONTROL OF NONCONFORMING ITEMS

$16.2 .15-1$

16.2.15.1 FAST FLUX TEST FACILITY AND USERS

16.2.15-1

16.2.15.2 COST PLUS AWARD FEE (CPAF) CONTRACTORS

16.2.15.3 SUPPLIER-FURNISHED EQUIPMENT

$16.2 .15-1$

$16.2 .15-2$

16.2.16 CORRECTIVE ACTION

$16.2 .16-1$

16.2.17 QUALITY ASSURANCE RECORDS

$16.2 .17-1$

16.2.18 AUDITS

$16.2 .18-1$

16.2.18.1 RESPONSIBILITY

$16.2 .18-1$

16.2 .18 .2 PLANNING ANO PERFORMANCE

16.2.18.3 REPORTING AND CORRECTIVE ACTION

$16.2 .18-1$

16.2.18-1

16.2.19 REFERENCES

16.2.19-1 


\section{IABLES}

Table

Page

16.2-1 Cross-Reference of Controlling Documents - Organization

T-16.2-1

$16.2-2$

Cross-Reference of Controlling Documents - Quality

$T-16.2-2$

Assurance Program

16.2-3 Cross-Reference of Controlling Documents - Design Control

$T-16.2-3$

16.2-4 Cross-Reference of Controling Documents - Procurement T-16.2-4

16.2-5 Cross-Reference of Controlling Documents - Instructions, T-16.2-5 Procedures, and Drawings

16.2-6 Cross-Reference of Controlling Documents - Document Control

$T-16.2-6$

16.2-7 Cross-Reference of Controlling Documents - Control of T-16.2-7 Purchased Items and Services

16.2-8 Cross-Reference of Controlling Documents - Identification T-16.2-8 and Control of Items

16.2-9 Cross-Reference of Controlling Documents - Control of T-16.2-9 Processes

16.2-10/11 Cross-Reference of Controlling Documents - Inspection T-16.2-10 and Test Control

16.2-12 Cross-Reference of Controlling Documents - Control of T-16.2-11 Measuring and Test Equipment

16.2-13 Cross-Reference of Controlling Documents - Handling, T-16.2-12 Storage, and Shipping

16.2-14 Cross-Reference of Controlling Documents - Operating T-16.2-13 Status

16.2-15 Cross-Reference of Controlling Documents - Control of T-16.2-14 Nonconforming Items

16.2-16 Cross-Reference of Controlling Documents - Corrective T-16.2-15 Action

16.2-17 Cross-Reference of Controlling Documents - Quality T-16.2-16 Records

16.2-18 Cross-Reference of Controlling Documents - Audits

T-16.2-17 


\subsection{QUALITY ASSURANCE}

\subsubsection{INTRODUCTION}

\subsubsection{PURPOSE}

This chapter describes the Quality Assurance Program Plan (QAPP) implemented by Westinghouse Hanford Company (WHC), for operation, maintenance, and modification of the Fast Flux Facility (FFTF). The criteria for the Quality Assurance (QA) program are described, and a broad overview of the method of implementation is provided. The documents by which the QA program is implemented, both by the QA department and by other organizations that perform or direct activities potentially affecting those functions important to the safety and quality of the FFTF, are listed in tables accompanying various sections of this chapter.

The organization of this chapter parallels that of American Society of Mechanical Engineers (ASME) Standard Nuclear Quality Assurance (NQA)-1-1989, (1) "Quality Assurance Program Requirements for Nuclear Facilities." Paragraphs 16.2.1 through 16.2.18 correspond to the 18 criteria found in NQA-1.(1)

\subsubsection{APPLICABILITY}

The QA program described in this chapter applies to all activities that could affect the safety and reliability of the FFTF during its operational phase. These include the methods by which quality-related activities of suppliers, contractors, and laboratories who provide equipment, services, and experiments to the FFTF are adequately controlled. The QA program applies to the entire FFTF Plant, including both safety-related items (as described in FFTF Final Safety Analysis Report [FSAR], Section 3.2) and nonsafety-related items. It is implemented using a graduated approach based on equipment safety classifications, found in Section 3.0 of this FSAR, and Impact Levels as defined in WHC-CM-1-3, (2) MRP 5.43. The program implements the requirements of ASME NQA-1 ${ }^{(1)}$ and WHC-CM-4-2. ${ }^{(3)}$ It is also consistent with the 18 criteria found in Appendix $B$ of the Code of Federal Regulations, 10 CFR 50.(4) 
The QA program, as implemented for code work, is described in WHC-CM-4-28. (5) Presently, WHC does not hold an ASME Certificate of Authorization, as it is not required for Section $X I^{(6)}$ work.

\subsubsection{PURCHASER (OWNER) ACTIONS}

The QA programs and quality-related activities of FFTF contractors, suppliers, and users are subject to review and audit by the U.S. Department of Energy (DOE) or its designated representatives at all times and in all places where such activities are being performed. All records and information developed of such activities are available to the DOE or its designated representative upon request. 


\subsubsection{ORGANIZATION}

\subsubsection{RESPONSIBILITY AND AUTHORITY}

The President, WHC, approves policy documents (WHC-CM-1-3) (2) that establish corporate policies, goals, and objectives for the QA program and establishes the responsibilities and authority of the QA department and other organizations whose work affects quality.

The FFTF organizations are held responsible for the systematic and adequate performance of all work that could affect the safety or reliability of the FFTF, in accordance with the requirements of the QA program. The qualityrelated responsibilities of each organization are identified in this chapter and are described in more detail in the implementing manuals and procedures.

The QA organization reports to the President, WHC, through management independent of the line organizations. The charter of the QA organization is to provide assistance to line organizations for implementation of a problemprevention-oriented QA program that al so has the capability of confirming, through independent verification, the attainment of quality. The $Q A$ organization is responsible for the following:

- Develop and administer the QA program

- Coordinate and integrate all quality audits

- Verify the attainment of required quality, including inspection, surveillance, investigative services, tracking, and trending

- Provide independent technical reviews, assessments, and evaluations or participate in these activities as independent reviewers

- Actively participate in the WHC Occurrence Reporting System as well as joining in on the resolution of quality-related problems

- Provide a system for evaluation and disposition of nonconforming items

- Ensure the proper cataloging and retention of quality records

- Provide independent review of design documents, operating procedures, instructions, standards, specifications, and 
manufacturing procedures to implement an error-prevention approach to work control and other quality engineering activities

- Provide surveillance of ongoing operations and real-time feedback on quality attainment

- Review the assignment of inspection, witness, and hold points in work controlling documents (travelers, and nonASME-related work packages) to provide objective evidence of quality attainment

- Inspect incoming material and material to be shipped to other facilities for repair, rework, or use

- Audit activities affecting quality and provide audit planning to ensure elements of the QA program are verified at regular intervals

- Procure third-party inspection services to perform Section XI ${ }^{(6)}$ inspections

- Maintain ASME Code QA programs and certificates needed to operate the Hanford Site

- Exercise the authority to suspend work when continuation could result in a violation of approved work requirements, product damage, or personal injury.

Each FFTF organization has the necessary authority to implement its assigned responsibilities. The FFTF Plant Manager has overall responsibility for compliance with the QA program. The FFTF FSAR, Chapter 13 describes the responsibility of FFTF organizations that are directly responsible for operation, maintenance, and modification of the FFTF. 


\subsubsection{QUALITY ASSURANCE PROGRAM}

\subsubsection{PLANNING}

This plan applies to the management of the QA program and to procurement, installation, testing, operation, maintenance, and modification activities. The application of the QA program is based on the classification of structures, equipment and systems, and impact levels. The classifications are outlined in Chapter 3.0, Section 3.2 of this FSAR and WHC-CM-6-27, (12) EI-86. Impact levels are defined in WHC-CM-1-3, ${ }^{(2)}$ MRP 5.43.

Changes to this FSAR chapter may be required for consistency with policy or procedure changes. Procedure requires processing FSAR changes in the same manner as design changes discussed in Section 16.2.3.14. Normal reviewers and approvers consist of QA, FFTF Engineering, Health \& Safety Assurance (HSA), and FFTF Operations; it may also include Environmental Assurance, if required. A DOE Richland Field office (RL) approval is required for changes classified as Impact 1 .

\subsubsection{IMPLEMENTING DOCUMENTS}

The policies, procedures, and instructions by which the FFTF QA program is implemented are identified below and referenced in Tables 16.2.1 through 16.2.18. The numerical column headings in these tables correspond to the document numbers below. The tables also list the specific sections within certain documents that implement applicable requirements.

1. HHC-CM-4-2, Quality Assurance Manual.

2 WHC-CM-4-8, Quality Assurance Instructions.

3. WHC-CM-6-27, Fast Flux Test Facility Engineering Instructions.

4. WHC-SP-0333, User's Guide for the Irradiation of Experiments in the FTR.

5. WHC-CM-4-39, Qual ification of NDE Personnel.

6. WHC-CM-6-4, Hanford Hoisting and Rigging Manual.

7. Administrative Procedures (Operations "A" Procedures).

8. WHC-CM-6-10, Welding Manual.

9. WHC-CM-2-1, Procurement Manual. 
10. WHC-CM-1-3, Management Requirements and Procedures.

11. WHC-CM-4-38, Nondestructive Examination Procedures.

12. WHC-CM-4-28, Quality Assurance Program Manual for ASME Code Section XI Activities for FFTF.

13. SD-FF-SISI-006, FFTF Surveillance and Inservice Inspection Requirements.

14. WHC-IP-0505, FFTF Driver Fuel Assemb1y Operating Procedures.

15. WHC-IP-0504, Core Component Control Inventory and Data Control Operating Procedures.

16. WHC-CM-8-8, Job Control System.

17. WHC-CM-6-19, FFTF Occurrence Management Procedures.

18. WHC-CM-6-14, FFTF Plant Policy Manual.

19. WHC-CM-8-4, 400 Area Support Services Manual.

20. WHC-CM-6-1, Standard Engineering Practices.

21. WHC-SP-0329, 400 Area Training Plan.

22. WHC-CM-8-7, Operations Support Services.

23. WHC-CM-2-2, Materials Management Manual.

24. WHC-CM-3-5, Document Control and Records Management Manual.

25. WHC-CM-4-5; Quality Assurance Qualifications and Instructions.

26. WHC-CM-2-14, Hazardous Material Packaging and Shipping.

27. WHC-IP-0705, Qual ity Assurance Program Plan for the Hazardous Materials Iransportation and Packaging Program.

These documents are revised and updated as necessary to reflect changes to regulations, codes, and standards and to incorporate changes resulting from operating experience.

\subsubsection{TRAINING AND INDOCTRINATION}

A training $\mathrm{plan}$ is maintained for the indoctrination and certification of quality control personnel performing inspections and evaluations. The QA department also provides orientation and indoctrination of nonQA personnel in $Q A$ requirements and functions.

Engineering provides seminars on codes, standards, engineering procedures, and other subjects. These seminars are available to personnel from other departments. Operations training and other training classes are conducted by the 400 Area Training group. 


\subsubsection{PERSONNEL QUALIFICATION}

The Manager, FFTF Quality Engineering, is required to have a technical college degree and a minimum of $7 \mathrm{yr}$ experience in quality engineering, preferably in the nuclear field. He/she must be knowledgeable in such areas as nondestructive testing, fabrication and construction practices, acceptance test programs, nuclear plant operations, and records management. He/she must have a thorough understanding of QA principles and be familiar with national standards, the ASME Boiler and Pressure Vessel Code, ${ }^{(6)}$ the Nuclear Energy Standards, and equivalent military standards.

The program for qualification of operating and maintenance personnel and for providing records as objective evidence of qualification is found in FFTF FSAR, Chapter 13. This program provides for retraining to ensure continued proficiency.

Auditing and surveillance by $Q A$ include checks to ensure that personnel qualifications are current and applicable to the work being performed.

Personnel who perform nondestructive examinations (NDE) of FFTF equipment, materials, or systems are formally qualified in accordance with WHC-CM-4-39(7) to Level II requirements as a minimum. Quality Assurance personnel who perform inspection and testing artivities (nther than NDE) to verify conformance to requirements during operation, maintenance, and modification, and on supporting procurement, fabrication, and construction, are formally qualified and certified for the work they perform per WHC-CM-4-5. ${ }^{(\theta)}$

Records supporting the certification of inspectors, welders, and nondestructive examiners are maintained by their managers. 


\subsubsection{MANAGEMENT ASSESSMENT}

The FFTF $P$ lant management is responsible for regularly assessing the QA program and reporting regularly and directly on the effectiveness of the WHC QA program to the President of WHC. The process for these assessments is identified in WHC-CM-4-2, ${ }^{(3)}$ QI 2.7. 


\subsubsection{DESIGN CONTROL}

\subsubsection{RESPONSIBILITY}

This section describes the controls used during the design (or redesign) of items for the FFTF. Westinghouse Hanford Company is responsible for the design of plant components, systems, replaceable core components, and FFTF experiments as required for refueling, plant modifications, major repairs, or experimental programs. Design control is provided by WHC when designs are solicited from architect/engineers, suppliers, and FFTF users.

\subsubsection{DESIGN PLANNING}

Engineering initiates and maintains schedules for preparation of design documents, review of interface requirements, verification of materials suitability, preparation of changes in the descriptions of system designs, qualification testing, conduct of design reviews, and release of design documents.

\subsubsection{DESIGN CRITERIA}

The safety and performance objectives and other basic criteria of new designs are reflected in the descriptions of system designs. The criteria include but are not 1 imited to materials, processes, interfacing characteristics, and operating parameters. Any changes to these criteria are also incorporated into descriptions of system designs.

\subsubsection{CODES, STANDARDS, AND PRACTICES}

Standards and ASME Code classifications that are incorporated into the design of new or replacement items are in accordance with system design requirements. Nuclear Energy (formerly RDT) Standards are used for items on which plant safety or relfability depends, except where industrial standards have been determined to be fully adequate. Redesigns generally incorporate the latest revisions of the applicable codes and standards in effect on the date of design approval. 
Exceptions that may be necessary to preserve maintainability or interchangeability are handled on a case-by-case basis.

Designated systems of the FFTF plant meet Section III of the ASME Boiler and Pressure Vessel Code, ${ }^{(6)}$ as will any major modifications to those systems. Maintenance and other modifications meet Section XI. One exception is that test vehicles, which are used for a limited time, will meet the technical requirements of Section III but are neither inspected by the authorized inspector nor stamped.

\subsubsection{ENGINEERING STUDIES}

Studies are made of new or revised designs to ensure that they satisfy the design criteria. Typical studies include stress analyses, seismic analyses, failure mode and effects studies, and operability and maintainability studies. Studies to be performed are identified in the design planning and are subject to design reviews.

Independent calculations are performed when required to verify those used to establish original designs. Calculations performed by the designer's supervisor normally are not considered as independent.

\subsubsection{PARTS, MATERIALS, AND PROCESSES}

Whenever possible, new and revised designs use materials, components, and processes already in use and proven at the FFTF. Engineering provides applicable data and documentation necessary to validate all changes requested, and establishes requirements for any design verification testing necessary for validation.

\subsubsection{DESIGN DESCRIPTIONS}

Descriptions of system designs approved for the original FFTF equipment are reviewed when new or revised designs are established. Changes to approved design descriptions and new design descriptions are submitted to RL for approval or information in accordance with established criteria. 
Descriptions of test designs are reviewed by WHC's Irradiation Test Management (ITM) and Representatives for Experiment Review (RER) committee. Test specifications are submitted by the user to WHC for review before procurement and fabrication of experiments (see Section 16.2.3.10.1).

\subsubsection{DESIGN DEFINITION AND CONTROL}

Procedures have been established for the definition and control of FFTF designs. These procedures are directly applicable to FFTF designs and to the approval of designs developed by other companies (e.g., architect/engineers, engineering firms, and design-and-build suppliers). In addition, Section 3 of NQA-1 ${ }^{(1)}$ is invoked on other organizations as applicable to ensure their use of adequate design control systems. Approval of FFTF users' designs is also required (see Section 16.2.3.10.1).

\subsubsection{DESIGN REVIEWS}

Reviews of planned irradiation tests are performed by ITM as described in FFTF FSAR, Chapter 13.

At the start of each major design effort, the cognizant engineer or manager determines and specifies the types of design reviews (formal or informal) and at what stages of design evolution these will be conducted. The design reviews are systematic evaluations to ensure agreement with design criteria, elimination of errors, and design optimization.

The procedure for formal design reviews provides for the appointment of a design review chairman and establishes his/her authority for organizing and conducting the review, and for resolving identified action items. The procedure identifies the organizations or functions to be represented and establishes the responsibility of the participants to review the data packages before the meeting and to resolve action items in a timely manner. Personnel who verify calculations in support of design reviews shall not be the same as those who performed the calculations originally. For formal design reviews, the majority of the design review committee were not directly involved in the development of the design. Agendas are used for all reviews. Action items 
resulting from the reviews are documented, scheduled, and resolved. Formal design reviews typically include representatives of all technical disciplines involved in the design, are applicable to the entire design, and require the use of checklists. Informal design reviews are typically aimed at specific design problems and involve only those personnel specifically needed to resolve the problem.

Formal design reviews are held, as a minimum, for all fuel and other major items before release of the design for fabrication.

Quality Assurance maintains an overview of the design review program through participation in the reviews and through audits or surveillances. In the reviews, QA concentrates on such aspects as completeness of design criteria, consistency of detailed design with the criteria, control of interfaces, acceptance criteria, interchangeability, and resolution of previous problems. Quality Assurance also overviews design review preparation, participation by appropriate disciplines, and followup to assess overall effectiveness.

\subsubsection{DESIGN VERIFICATION TESTING}

Design verification testing in the FFTF will consist of irradiation tests for advanced core components and materials. Design verification testing is also performed as necessary to ensure the safety and performance of FFTF plant or equipment modifications.

\subsection{Experiment Design}

Irradiation test programs are planned and conducted in accordance with comprehensive management controls. These controls provide for complete disclosure of the design, fabrication, QA program, safety analysis, and test conditions by the experimenter (FFTF user); reviews and approvals by appropriate FFTF organizations and by the DOE; receipt inspection and protection of the experiments; use of reactor run plans; and control over the examinations and any reinsertion of the experiments. 


\subsection{Test Requirements}

For core component-type tests, the FFTF user holds discussions with ITM and obtains a technical feasibility acknowledgment letter from ITM following a review by the RER. After obtaining an approval in principle (AIP) from the DOE, the user prepares the design description, safety analysis, test specifications, and a description of the user's QA program. This information is submitted for a review coordinated by ITM and to the RL for information. The test specifications undergo formal design review and are then submitted to the DOE for approval.

\subsection{Test Planning}

Following design approval, the user proceeds with experiment fabrication and the preparation of records of fabrication, inspection, and testing. These records are submitted to WHC for review and approval. The ITM oversees performance to ensure that the following are completed: independent safety evaluation, inspection of the experiment, a final review of the documentation, and a letter approved by the FFTF Plant Manager authorizing insertion of the experiment.

\subsection{Procedures}

Irradiation, handling, and examination of irradiation test experiments are performed in accordance with approved operations, test plans, and IEM cell planning. The user will be notified of any departures from planned conditions; and, when possible, his/her prior concurrence will be obtained.

\subsection{Readiness Reviews}

Review of descriptions of test designs and approval of test article insertion along with the establishment of some requirements by the Readiness Review Board (RRB) constitute the readiness review of irradiation tests. 


\subsection{Test Reviews}

Complete data shall be provided to the user on the irradiation and examination of experiments. The user is responsible for conducting reviews, as necessary, to ensure that valid conclusions are drawn from the data and that these conclusions satisfy the test objectives.

\subsection{Facility/Equipment Design}

Design verification testing for FFTF modifications (FFTF design verification test) is accomplished through similar but separate controls. These provide for the preparation and approval of test requests by a test requester, who is usually the cognizant design engineer, and of test $p l a n s$ by the test performer to describe how the tests will be accomplished.

\subsection{Test Requirements}

Requirements for FFTF design verification testing are specified in test requests. These are prepared by the designer and identify test objectives, test parameters, the item or process to be tested, the tests to be performed, and the facility to be used. They identify the test articles and their disposition. They also specify requirements for data acquisition and reduction, pre- and post-test examinations, any archive samples, any readiness reviews, documentation, and reporting. The QA requirements for the test programs are also included.

\subsection{Test PIanning}

Test plans for FFTF design verification tests are prepared by the test performers in response to the test requests and are submitted to the test requester and cognizant quality engineer for approval. These plans describe in detail how the requirements of the request will be accomplished, including the $Q A$ requirements. 


\subsection{Procedures}

Procedures for conducting FFTF design verification tests are included in test plans. These procedures identify the prerequisites for conducting tests and define the detailed test evolution and data requirements. Procedure changes are approved by the test performer, and also by the test requester and cognizant engineer when the requirements of the test request may not be met.

\subsubsection{0:2.4 Readiness Reviews}

Readiness reviews of FFTF design verification tests will be held before important test evolutions when required by the test request and the test plan.

\subsection{Test Reviews}

The test requester will review the results of FFTF design verification tests. Such reviews may be included in design reviews as described in Section 16.2.3.9.

\subsection{Iest Items}

The description of a test design includes the requirements for storage and protection of irradiation test experiments before irradiation, for IEM cell examination, and for requalification before any reinsertion. These requirements are satisfied through FFTF planning and in accordance with existing procedures.

Test requests identify design and fabrication requirements for test items and specify any requirements for their characterization and protection. When an item ultimately is to be used in the FFTF, requirements are specified for its post-test inspection and for any maintenance to restore it to conformance with design requirements. 


\subsection{Test Equipment and Fluids}

Descriptions of irradiation tests and test requests for FFTF design verification tests specify any special requirements for test equipment or for the characterization and control of test fluids.

\subsection{Data Acquisition Equipment and Methods}

Test design descriptions and test requests may specify the accuracies and precision required for the gages, instruments, analyses, and other data acquisition equipment and methods, including any requirements to evaluate these accuracies and precision before performance of the test.

\subsection{Failure Analysis}

Premature failures of irradiation test experiments and of FFTF design verification tests may be investigated and analyzed. Those meeting the criteria for occurrence reports will be reported as such. Such investigations shall appear in test records and reports.

\subsection{Test Results}

Results of both irradiation tests and FFTF design verification tests shall be recorded, analyzed, and reported as required by the description of the test design or by the test request.

\subsection{Test Récords}

Test design descriptions and test requests identify the records to be kept and their retention periods. These are consistent with DOE Order 1324.2 ( $^{(9)}$

\subsubsection{ITEM QUALIFICATION}

Items selected for new or revised designs (whose adequacy cannot be established through studies and calculations, as discussed in Section 16.2.3.5) are qualified by design verification testing, by comparison 
to a previously qualified item, or by use experience. The basis of selection will be documented by the cognizant design organization and will be subjected to independent review through the design review or document review processes described in Sections 16.2.3.9 and 16.2.3.14.

\subsubsection{CHANGE CONTROL}

Information Resource Management maintains the engineering documents that define the original construction of the FFTF and all new or revised designs, including records of approvals. The ITM maintains the documents that are associated with test experiments, including changes.

Suppliers, users, and contractors are required to establish and implement systems that ensure required approval of specified documents and changes are obtained before implementation.

A centralized print control system is used to ensure that drawings used are current. Only specially stamped prints may be used for construction. When a change notice affecting a drawing has been approved and issued, a copy of the notice is stapled to each print, and a stamp is placed on the print indicating that a notice or notices are outstanding. When a later revision of the drawing is released, the obsolete prints are removed from the print stations, logged, and destrnyed. This system is used for the FFTF and ArchitectEngineer/Construction $(A-E / C)$ contractor work, or for outside contractor work.

\subsubsection{INTERFACE CONTROL}

The FFTF users are required to submit conceptual, final, and as-built designs of their experiments. These are required to be in consonance with the applicable descriptions of system designs. The WHC's ITM coordinates reviews to ensure that the experiments will interface with the FFTF in all respects. Characterization of the experiments also ensures that design requirements for interfaces have been met. 
Assurance that any new or redesigned equipment items will interface properly with the test of the $p l a n t$ is achieved through reviews of their designs by WHC engineers who have cognizance of the interfacing equipment, facilities, or systems. These reviews are described in Section 16.2.3.14.

\subsubsection{LEVELS OF CONTROL}

The FFTF users' design descriptions, which outline the design, fabrication, QA program, and other parameters for experiments, are submitted to the ITM. The ITM obtains reviews and approvals from all necessary disciplines, including $Q A, H S A$, and the RER.

There is an established system for the review and approval of FFTF design documents and changes. Under this system, the cognizant engineer determines the list of reviewers and approvers in accordance with established procedures. Classification criteria for the approval level are based on the plant impact of the new design. A design that has a technically minor plant impact does not require as high a level of approval as a design of potentially high impact.

Procedures for determining the list of reviewers and approvers identify the various organizations and disciplines that must review or approve its technical content. These criteria provide for appropriate reviews and approvals by QA, HSA, Environmental Assurance, and other organizations. Quality Assurance reviews such aspects as the completeness and adequacy of acceptance criteria, provisions for item protection, the clarity and completeness of technical requirements, and $Q A$ requirements, including the selection and application of QA standards and documentation requirements. Documented comments, approvals, and disapprovals are accumulated and reconciled by the cognizant engineer, who then obtains approvals. When the RL approval is required, the document is transmitted to them by letter.

\subsubsection{QUALITY RECORDS}

The WHC maintains the record copies of approved drawings and specifications, evidence of their approval, descriptions of system design, and official 
correspondence. The responsible FFTF technical organizations initially maintain record copies of design reviews and followups, Hold and TBD reports, drawing lists, engineering studies, AIPs, test requests, and test plans. (One exception is that the ITM maintains logbook records [including copies and/or originals] of all design data related to experiments to go into the FFTF.) When records that are kept by FFTF technical organizations are of no further current use to the holder, they are microfilmed for long-term retention. The ITM inactive (completed) records are archived for long-term retention. Records retention and storage are described in Section 16.2.17. 


\subsubsection{PROCUREMENT DOCUMENT CONTROL}

\subsubsection{PROCUREMENT REOUIREMENTS}

Purchase orders are prepared in accordance with WHC-CM-2-1 ${ }^{(10)}$ and incorporate the latest revisions of applicable technical documents, such as standards, specifications, and drawings, except when earlier revisions are required for interchangeability or for specific Code contract dates. Only approved drawings and specifications are used in request for proposal packages. Specifications identify the requirements to be met by the suppliers' QA system and any supplier documents to be submitted for information or approval. Drawings; QA program indexes and manuals; inspection and test plans; nonconformance reports (NCR); and procedures for processes, nondestructive testing, cleaning, cleanliness control, and other quality-sensitive activities are examples of such documents. Specifications also identify the documents to be submitted or retained by the supplier that provide objective evidence of quality, such as certifications of test and analysis, radiographs, inspection reports, and ASME Code datasheets. Retention periods (as described in Section 16.2.17) are specified for supplier-retained records.

Purchase orders also incorporate any appropriate $Q A$ clauses and administrative requirements that supplement and implement the $Q A$ requirements in the specifications. For example, they include the instructions for submitting documents for information or approval. They also establish WHC's right of access to supplier facilities and records for source inspection and audits, including requirements for advanced notification of inspection or tests to be witnessed by a QA engineer or WHC representative.

Acceptance criteria for purchased items appear in the purchase order and/or in attached drawings or specifications.

Spare parts, equipment, and other materials are procured, received, inspected, handled, and stored to requirements specified by the originator with concurrence by $Q A$ as described in Section 16.2.3.14. 
Procurement documents for spare or replacement equipment items provide controls at least equivalent to those used for the original equipment through the use of the same or updated revisions of the original specifications. Controls on spare parts are established as necessary to obtain satisfactory performance, because there usually is no basis for direct comparison with controls on original equipment parts.

Commercial-grade items are identified on the purchase order by the manufacturer's published product description (i.e., catalog number), and are processed in accordance with WHC-CM-4-2, ${ }^{(3)}$ QI 7.5 , as applicable.

\subsubsection{PROCUREMENT DOCUMENT REVIEW}

Approved purchase requisitions constitute the buyer's authority to solicit bids, select suppliers, and place purchase orders or purchase order changes (alterations). Procedures require that purchase requisitions for items whose operation or failure could affect personnel, environmental, or plant safety be reviewed and approved by $Q A$ to ensure that appropriate procurement requirements per Section 16.2.4.1 have been included in the requisition or in attached documents. The purchase requisition, with the $Q A$ approval signature, is included in the purchase order file. The $Q A$ review ensures that attached design documents incorporating appropriate $Q A$ requirements such as portions of NQA-1 ${ }^{(1)}$ have been properly approved, that other $Q A$ requirements to be invoked are appropriate, that approved suppliers are required when appropriate, and that provision is made for source and receipt inspection as necessary.

After contract award, documents submitted by the supplier for approval or information are reviewed by FFTF organizations, including $Q A$, as described in Section $16 \cdot 2 \cdot 3 \cdot 14$. 


\subsubsection{INSTRUCTIONS, PROCEDURES, AND DRAWINGS}

\subsubsection{POLICIES AND PROCEDURES}

Quality Assurance policies and procedures for the FFTF are established to ensure that the quality of work being performed, consistent with item complexity and consequences of failure, is in compliance with applicable standards, regulations, and codes; and is consistent with this description of the QA program.

The policies and procedures that control activities affecting the quality of the FFTF provide for the preparation, review, approval, and change control of work-defining documents, such as drawings, purchase requisitions, specifications, and procedures. Except as described in Section 16.2.3.14, changes to these documents are required to be reviewed and approved by the same organizations that reviewed and approved the original documents. The documents are to address the appropriate requirements for safety and quality, including acceptance criteria to verify that important activities have been satisfactorily accomplished. Applicable documents are required to be available at the work location before the start of work. They are also required to provide necessary records of performance. The uses of these documents are described throughout this chapter.

Three manuals, WHC-CM-4-2, (3) WHC-CM-4-28, (11) and WHC-CM-4-5, ${ }^{(8)}$ are approved by the Manager, QA. When these procedures prescribe action by other departments, they are also reviewed by the affected department managers or approved by the President, WHC. Administrative procedures that control work affecting the $Q A$ program are required to be reviewed and concurred by $Q A$ before initial issue or revision. Examples of manuals containing such procedures are WHC-CM-6-27, (12) WHC-CM-8-4, (13) and WHC-CM-6-1. (14) Qual ity Assurance verifies that the procedures reviewed are in compliance with the company's quality policy and with applicable codes, standards, and regulations. The procedures must also be complete, adequate, and consistent with the FFTF FSAR. 
Manuals containing procedures that affect the QA program are under controlled distribution. Manual holders are identified; both revised or added procedures are transmitted to them with instructions for updating the manual, including revisions to the table of contents, so that the completeness and currentness of the manual can be verified.

The QA policies also assign each department with the responsibility for implementing those procedures that affect the QA program.

\subsubsection{WORK INSTRUCTIONS}

Work Instructions are developed using WHC-CM-8-8 ${ }^{(15)}$ implementing procedures. Work Instructions may be of a simple nature but may be supplemented by other documents that provide detailed criteria and step-by-step instructions for the work, including provision for inspections or other verification. These include such documents as the Repair Program and traveler for work on ASME Code items. In processing the work documents, requirements for approval by other organizations such as QA, Engineering, HSA, and Environmental Assurance are determined and documented in accordance with specified criteria.

Changes are also reviewed and approved in accordance with specified criteria.

Quality Assurance reviews are to ensure that adequate provision is made for testing or otherwise verifying successful completion of work, including the insertion of quality control (QC) or NDE Hold points, as necessary, and the inclusion of acceptance criteria that are at least equivalent to those for the original item. Quality Assurance also reviews work-controlling documents and changes to ensure that adequate precautions are taken to protect the work, including cleanliness control, the use of lanyards and caps or other precautions against foreign articles, and lifting and handling controls, if required.

In cases where supplementary tests or inspection instructions are needed, $Q A$ ensures that these documents provide such prerequisites as calibrated instrumentation and appropriate inspection or test equipment; recording necessary data, the date of inspection or test, and the identity of the 
inspector or tester; and that any required drawings or specifications are attached. Quality Assurance also verifies that adequate instructions are given to ensure successful job completion.

Procedures have been established for the preparation, approval, and release of work-controlling documents for performance. The FFTF Operations has responsibility for release of work-controlling documents per administrative procedures.

Procedures have been established to ensure that work-controlling documents, including those in use, are consistent with the latest approved design changes. The Person-In-Charge (PIC) is responsible for ensuring that the approved instructions are followed during performance of the work and required verifications are signed. The FFTF Operations reviews the master copy for evidence of successful and verified completion of all work before accepting the item for operation. The master copy is then reviewed and approved in accordance with specified procedures and sent to Information Resource Management. Retention and storage are as described in Section 16.2.17.

Procedures are developed for preventive and other repetitive maintenance and surveillance tasks. Criteria for review and approval of these procedures are provided. A current list of these procedures, including revision numbers, is maintained.

\subsubsection{OPERATING PROCEDURES}

Operations procedures and changes are approved by the FFTF Plant organization and other appropriate organizations, including QA, HSA, and Environmental Assurance, in accordance with established criteria. Procedures are required to specify the actions to be taken under normal, infrequent, alarm, and recovery conditions. 


\subsubsection{REFUELING INSTRUCTIONS}

Detailed step-by-step refueling and IEM cell instructions are prepared by FFTF Work Control. Criteria for review and approval of these instructions are provided in administrative procedures.

\subsubsection{OPERATION CONTROL}

The coordinated plans and schedules for plant startup, operation, and outages are reviewed and approved by established FFTF organizations in accordance with existing procedures, to ensure that the requirements of all disciplines, such as QA, Radiological Safety, HSA, and Engineering are satisfied. 


\subsubsection{DOCUMENT CONTROL}

All documents that are used to perform administrative, design, operating, and maintenance activities at the FFTF are prepared, issued, and changed in accordance with approved procedures. They are reviewed for adequacy by personnel who have the proper background for the scope of the review being performed. They are approved for release by authorized personnel in accordance with WHC-CM-1-3, (2) MRP 5.43, "Impact Levels." Document control procedures of FFTF users and outside contractors are subject to review and must contain similar controls. Work control procedures require that workdefining documents be available before work is started.

A document control list for operating procedures is maintained, identifying all approved procedures and revision numbers and controlled locations. Copies of the procedures and changes are hand delivered and incorporated into binders that are maintained at the watchstations; and copies of superseded documents are removed.

All activities shall be performed to properly approved and releasd documents. 


\subsubsection{CONTROL OF PURCHASED ITEMS AND SERVICES}

The procurement of all items and services for use at the FFTF shall be planned and controlled in accordance with approved procedures. They shall be procured using approved procurement documents that shall include released specifications and/or drawings as required.

When required, procurement shall be made from suppliers who have an approved quality program based on the appropriate national standard. Suppllers and the products they furnish shall be evaluated for acceptability through the following means, as appropriate: source surveillance and inspection, evaluation of objective evidence furnished by the supplier, and audits.

Source surveillance and inspection may be used on selected contracts. The decision is based on the complexity and importance of the items being procured, the quality of the supplier's past performance, and the ability or inability to fully inspect the item upon receipt.

When material is procured requiring traceability to Chemical Analysis and/or Mechanical Test Reports, CQ identification may be used. (See WHC-CM-4-2, (3) Appendix A, Clause C05.)

When required, purchased items shall be receipt inspected by QA personnel in accordance with WHC-CM-4-8, (5) QAI 7.1 , to verify conformance with purchase order requirements. When found acceptable, items shall be tagged with an Acceptance and Routing History (A\&RH) tag (Accept tag). 


\subsubsection{IDENTIFICATION AND CONTROL OF ITEMS}

The system for identification and control of materials used in the fabrication of items for the FFTF applies from material receipt, through fabrication, to end item use. It provides the following: traceability of end tems to raw materials when specified or when required by code; indication of quality status on travelers; tagging or other suitable identification of inspected items as acceptable, conditionally acceptable (with conditions noted), or nonconforming; identification of expiration dates on age-controlled items; control and use of stamps by inspectors; and use of controlled storage areas. Controls over welding include locked and limited access weld rod storage areas. Weld records are used to record the welder, location of welds, base material heats, and weld repairs.

Procedures used for fuel assembly provide complete records of the identification and location of fuel pins and components incorporated into each assembly.

The Hanford A-E/C contractor uses standard instructions, which are reviewed by FFTF staff, for the identification and control of materials from receipt to delivery or installation of the end item.

The FFTF users are required to establish appropriate procedures for the identification and control of materials used in experiments. 


\subsubsection{CONTROL OF PROCESSES}

\subsubsection{FABRICATION AND ASSEMBLY PROCESSES}

Shop fabrication by FFTF/FMEF Maintenance of items for the FFTF is controlled through the use of work-defining documents, which specify the work prerequisites, the work to be done, the equipment and protective measures to be used, the materials to be used, and the sequence to be followed. These forms provide the records of accomplishment and accompany the material. They include the Integrated Work Sequence/Inspection Traveler in Technical Shops for machining work and the Fabrication/Inspection Traveler in Laboratory Maintenance and Craft Support for fabrication, welding, and installation. The travelers and changes are prepared and approved by the cognizant engineer. They are then reviewed by the cognizant quality engineer, who ensures that complete acceptance criteria have been provided. Any cleaning and cleanliness control requirements are included. Inspection Hold points are noted.

\subsection{Process Qualification}

The FFTF implements a system for the qualification of welding procedures and personnel. Procedures, based on established welding processes, are prepared and indicate allowable ranges for essential variables such as joint geometry, current, and positions. Specimens are prepared and tested to qualify procedures and welders. Records of qualified procedures and personnel are maintained and are readily retrievable. A similar system is used by the $A-E / C$ contractor and is subject to FFTF management approval (for use of specific procedures) and to surveillance and audit (for evidence of procedure and personnel qualification).

The FFTF users must qualify welding and other special process procedures (see Section 16.2.9.1.4) and personnel who perform these activities, and submit evidence of such qualifications upon request. 


\subsection{Nondestructive Examination}

Nondestructive examination is performed at the FFTF in the course of maintenance or modification work, in portions of the Surveillance and In-Service Inspection (SISI) program, in fabrication of experiments, in overchecking of core component cladding for integrity, and in inspections of procured and assembled core components. Testing is done in accordance with procedures approved by examiners qualified under WHC-CM-4-39, (7) Level III. These procedures provide appropriate controls to ensure valid test results, such as the use of technique sheets and qualification films for radiography, and directions for checking setups for ultrasonic examinations.

Qualification requirements for NDE personnel were discussed in Section $16.2 \cdot 2.4$.

The A-E/C contractor has controls similar to those at the FFTF and those controls are subject to FFTF surveillance and audit.

The FFTF management invokes appropriate requirements for the use and control of nondestructive testing upon FFTF users. Procedures, including radingraphic technique sheets and films, are required to be submitted for approval. Receiving inspection examinations are used appropriately to ascertain the adequacy of NDE performance.

\subsection{Cleaning}

Required cleaning and cleanliness controls for fabrications by personnel from the FFTF and the $A-E / C$ contractor are incorporated into travelers and other work-defining documents. The FFTF users are required to use appropriate procedures, which are subject to concurrence by FFTF management.

\subsection{Other Spectal Processes}

Appropriate controls have been established over electrical cable pulling, splicing, terminating or routing, heater brazing, soldering, and concrete anchor bolt installation. New, special processes are evaluated by QA and controls are developed as appropriate. 


\subsubsection{0/11 INSPECTION AND TEST CONTROL}

\subsubsection{0/11.1 PLANNING}

Documents are established to control the fabrication and assembly of FFTF equipment, core components, and experiments; as well as FFTF shop repair, in-plant installation, operational inspection, and testing. These documents include the requirements to be imposed on the Hanford Site A-E/C contractor and experimenters that use the FFTF.

\subsubsection{0/11.2 INSPECTION AND TEST PLAN}

Quality Assurance reviews all work packages and accompanying documentation related to equipment whose operation or failure could affect personnel, environmental, or plant safety. During this review QA determines if inspection and test $p l a n s$ are needed. Inspection and test $p l a n s$ are used for all core components. The FFTF users' inspection and test plans are submitted to RER, which include FFTF management representatives, for approval. Inspection and test planning for fabrication and installation of FFTF equipment is provided with the work instruction. Operational inspection and test requirements are defined by the plant protective maintenance program.

\subsubsection{0/11.3 INSPECTION AND TEST}

\subsubsection{0/11.3.1 General requirements}

Inspections and tests are performed in accordance with specified requirements. Quality Assurance reviews the inspection and test planning to ensure completeness and accuracy, to ensure that necessary records are provided, and to insert QC Hold points, as needed. Sufficient independent verification is performed to verify the achievement of quality. The verification is normally performed by QA.

When QA concurrence is obtained, independent verification of operating activities (work functions associated with normal plant operation, routine maintenance, and technical services routinely assigned to the operating 
organization) may be conducted by qualified personnel not assigned first-line supervisory responsibility for performance of the work.

Surveillance inspection and testing programs to ensure the continued operability of the heat transport systems and other items directly related to safety and operating limits are described in Chapters 5 and 17 of this FSAR. These chapters identify the components affected and establish for each the types of checks to be made and their minimum frequencies. Checks include calibrations, operability tests, functional tests, and examination for pressure boundary integrity. Integrity examinations include remote or direct visual inspection, tensile testing of coupons, and nondestructive testing.

\subsubsection{0/11.3.2 Procedures}

Procedures are used as necessary to ensure adequate and consistent performance of inspections and tests, and FFTF users are required to do the same. The use of such procedures is called out in inspection and test plans, travelers, and other work-defining documents. Quality Assurance prepares or approves such procedures and ensures that they identify what is to be inspected or tested and which organization is to perform the inspection or test. Quality Assurance ensures that (1) acceptance criteria are included, (2) the inspection or test method is defined, (3) the governing drawings or specifications are referenced and their use invoked as necessary, (4) precautions for item protection and inspection/test prerequisites are defined, (5) provision is made for recording qualitative or quantitative evidence of acceptance or rejection, (6) the inspector or tester is identified, and ( 7 ) the date of performance is stated. After all data have been recorded, the completed procedure or the datasheets referenced to the procedure become a quality record as discussed in Section 16.2.17.

\subsubsection{0/11.3.3 Completed Item Inspoction and Test}

Final inspection and testing is required for all experiments and for items fabricated by WHC or an A-E/C contractor. A functional retest, if required, is performed after work is completed on installed equipment at the FFTF. 


\subsubsection{0/11.4 INSTALLATION INSPECTION}

Systems have been established by WHC and the $A-E / C$ contractor for the inspection of installation and construction work they perform. These systems include Hold points and surveillance of the $A-E / C$ contractor inspections by WHC. Westinghouse Hanford Company and the A-E/C contractor procedures prohibit the bypassing of Hold points. Outside contractors are required to establish effective inspection programs for their work, which are also subject to FFTF controls.

Inspections are normally specified only as steps in the travelers or other work documents, but instructions or procedures are included if the inspections are sufficiently complex. In either case, the characteristics and activities to be inspected and the organization responsible for performing the inspection are identified. Drawings or specifications with the traveler provide the acceptance criteria. The method of inspection is identified and described in necessary detail. Provisions are made for recording the inspector's identity and for qualitative or quantitative data indicating acceptability or rejection, including reference to any NCRs. Upon completion, the traveler and any inspection procedures are retained at the FFTF as records, as described in Section 16.2.17. 


\subsubsection{CONTROL OF MEASURING AND TEST EQUIPMENT}

\subsubsection{MEASURING AND TEST EQUIPMENT CALIBRATION AND CONTROL}

Measuring and Test Equipment (M\&TE) are used at the FFTF for determining item acceptability, verifying correct facility operation, or obtaining controlled experimental data. The controls include periodic calibrations against national or other recognized standards, the use of standard calibration procedures, the use of stickers that identify status and calibration due dates (except for installed FFTF instruments where calibration status is controlled by computer listings), and instructions on selection of M\&TE and interpretation of readings. Computerized recall systems are used to notify custodians of M\&TE items due for recalibration, and followup is made to ensure timely performance. The custodial organization manager is responsible for ensuring that personnel using M\&TE are properly trained. Custodians submit M\&TE for recalibration if potentially damaged.

If M\&TE is found to be out of tolerance upon recalibration, items inspected or data taken since the last calibration are considered suspect. The custodian is required to review them and to determine and document appropriate action. Such action includes the initiation of NCRs whenever necessary.

The FFTF Plant-installed instruments are classified into categories for calibration control. Categories are identified and defined in Administrative Procedures.

The A-E/C contractor has similar controls over its M\&TE, which are subject to FFTF review and concurrence. Any outside contractors are contractually required to establish and maintain controls over their M\&TE.

The FFTF users are required to establish and maintain control over M\&TE used in the fabrication of experiments. 
Selection of M\&TE is controlled to ensure that items are of proper type, range, accuracy, and tolerance to determine conformance to specified requirements. Selection shall be based on nationally approved codes and standards, or WHC-CM-4-2, (3) when applicable codes and standards are not identified. 


\subsubsection{HANDLING, STORAGE, AND SHIPPING}

\subsubsection{HANDLING}

Cranes and other hoisting equipment are maintained and operated in accordance with the applicable requirements of the Occupational Safety and Health Administration (OSHA) and WHC-CM-6-4. (16) Fixtures and procedures for the special handling of items fabricated or assembled at WHC are planned and provided as needed to ensure against damage. Similar controls are implemented by the $A-E / C$ contractor.

The FFTF users and suppliers are required to establish appropriate controls over the handling of critical items.

\subsubsection{PRESERVATION, PACKAGING, AND STORAGE}

All materials, parts, and components in Materials Management-controlled facilities shall be maintained to minimize damage or lowering of quality because of contamination, deterioration, or physical damage. When required, inspections and routine maintenance will be performed and documented on a periodic basis to ensure that the integrity of each item and its container is maintained.

Required procedures for the proper preservation, packaging, and storage of items fabricated at WHC are incorporated into travelers or other work-defining documents.

The FFTF users and suppliers are required to establish and implement appropriate procedures for the preservation, packaging, and storage of FFTF items.

When necessary, special procedures are used for handling and environmental control during receiving and storage to prevent soiling, damage, or deterioration. Items with limited shelf lives are identified, and their expiration dates are logged. 


\subsubsection{SHIPPING}

The FFTF users' and suppliers' shipping plans must be reviewed by FFTF management, as necessary.

Radioactive shipments to and from the FFTF are controlled by procedures prepared by specialists and approved by the appropriate organizations, which may include HSA, QA, and Environmental Assurance. (See References WHC-CM-2-14 ${ }^{(17)}$ and WHC-IP-0705. ${ }^{(18)}$ ) 


\subsubsection{INSPECTION, TEST, AND OPERATING STATUS}

Procedures and methods of indicating equipment status are provided, including procedures for tagging equipment and systems that are out of service to ensure against their inadvertent operation. These tags are affixed by FFTF Operations personnel and can be removed only by FFTF Operations personnel following verification that the necessary maintenance or other work has been successfully accomplished. Compliance is verified by $Q A$ during surveillance activities.

Quality Assurance uses stamps and signoffs on travelers and other workdefining documents, including identification of any NCRs, to identify and describe the quality status of items. Stamps are used to indicate conformance and are applied only to paperwork. Stamps are numbered and issued to individuals. Records of stamp assignments are maintained and periodic inventories are made. Tags are physically attached to materials and parts to identify their quality status. Tags used include the A\&RH or Accept tag, the Hold tag, and the Conditional Acceptance tag (with conditions noted). The A\&RH or Accept tag may be removed by the cognizant organization performing work after determining that the item to be installed is correct. Procedures require that Hold tags be removed only by the organization that applied them. Conditional Acceptance tags are removed by the QA inspector after resolution of the conditional acceptance. 


\subsubsection{CONTROL OF NONCONFORMING ITEMS}

\subsubsection{FAST FLUX TEST FACILITY AND USERS}

The FFTF users' procedures for control of nonconformances are subject to FFTF review to ensure that nonconformances are adequately recorded, verified, and dispositioned; that nonconforming items are segregated, protected, repaired, reworked, and reinspected or retested, as applicable; and that ultimate disposition is documented and identified.

Items fabricated by WHC that are determined to be nonconforming are segregated where feasible, a Hold tag is affixed to the component or to the traveler that accompanies the component, and an NCR is initiated. An NCR disposition is determined and approved by the cognizant engineer, with concurrence by $Q A$ as a minimum. When repair or rework is specified, the repair/rework procedure is documented and approved. If applicable, cause and corrective action are also determined. Following disposition and any required rework, repair, and reinspection or retest, the NCR is closed out, the Hold tag is removed, and the item is retagged with an A\&RH or Accept tag, if acceptable. Reinspection and retest are required to be performed in the same way as for the original. A new NCR is initiated if the item is still nonconforming.

Nonconformances discovered during plant operation are identified by a Plant Work Request for correction and are tracked by the Plant Tracking System. Nonconformances requiring investigation for cause and corrective action are documented by an NCR or under the provisions of the occurrence reporting procedures.

\subsubsection{COST PLUS AWARD FEE (CPAF) CONTRACTORS}

The A-E/C conlractor has established controls over its nonconformances, which are subject to FFTF review and concurrence. These controls shall include the initiation and submittal for approval of all NCRs concerning nonconformances on FFTF equipment and material or repair of that equipment or material. The proposed repair procedure is included with all NCRs, if appropriate. 
Procedures also provide for tagging and segregation, where appropriate, of all nonconforming items and the initiation and appropriate approval of A-E/C contractor NCRs. Reworked or repaired items are reinspected or retested by the same methods as for the original test or inspection.

\section{2 .15 .3 SUPPLIER-FURNISHED EQUIPMENT}

When necessary, suppliers are required to establish procedures for the control of nonconforming items. These procedures ensure that nonconformances are recorded and verified; that their disposition is determined in accordance with contract requirements; that nonconforming items are segregated, protected, repaired, reworked, and reinspected or retested as applicable; and that ultimate acceptance is documented and identified. Reinspection and retesting are done by the same methods as the original inspection or test. Suppliers' requests for acceptance or repair of nonconforming items, including applicable repair procedures, are required to be submitted to the FFTF for approval. They are to describe the nonconformance, indicate and justify the disposition, and document the results of inspection or testing following any repairs.

Items found to be nonconforming at receiving inspection are segregated and tagged as necessary. The cognizant engineer determines disposition, with QA concurrence, and the NCR is then processed in accordance with approved procedures. 


\subsubsection{CORRECTIVE ACTION}

Conditions adverse to quality are revealed through investigation of nonconformances and occurrence reports and through audits. The procedures for these provide for systematically obtaining commitments for corrective action from responsible management and for followup to verify the completion and effectiveness of such action. Emphasis is placed on true corrective action, i.e., el iminating the root cause of the condition, as contrasted to remedial action, i.e., fixing the specific situation. Adverse conditions may also be revealed through trend analysis and direct observation.

Reports of problems experienced elsewhere are also reviewed for possible applicability to the FFTF. Examples of such reports include external Occurrence Reports and NRC Notices, Circulars, and Bulletins. Applicable potential problems are reported to responsible management for investigation and appropriate action.

The FFTF users, suppliers, and subcontractors are required to establish corrective action systems when necessary. 


\subsubsection{QUALITY ASSURANCE RECORDS}

The QA records for construction of the original plant, including those for purchased components and for construction tests, are protected and indexed for ready retrieval. Records of acceptance (preoperational) tests were accumulated, filed, and indexed by Test Engineering and were turned over to Information Resource Management upon completion of the test program.

All records of the initial plant, except for radiographs, are either microfilmed or left in hard copy. They are indexed and retrievable.

Radiographs are stored in the DOE records holding area that serves the entire Hanford Site. This area meets the requirements of Federal Property Management Requirements (FPMR), Section 101.11.5, for microfilm storage with respect to fireproof construction, sprinkling, alarms, and humidity and temperature control. Ultimately the radiographs are shipped to the Federal Records Center in Seattle, which also meets these requirements.

Silver master copies of microfilm and microfiche are turned over to the DOE holding area and eventually to the Federal Records Center.

Retention periods for initial plant construction and test records are in accordance with DOE Order 1324.2. (9) This requires that records of significant value in demonstrating capability for safe operation; maintaining, reworking, repairing, replacing, or modifying an item; determining the cause of an accident or malfunction; and those that provide baseline data for in-service inspection shall be retained until the item is removed from service. Lesser retention periods are specified for other records; i.e., those that have no use after the first overhaul or reload, those that are needed for warranty purposes, and those that are of no value after the start of operation. Where the ASME Boiler and Pressure Vessel Code specifies longer retention periods than DOE Order $1324.2,^{(9)}$ the Code requirements are met.

Generally, records classified as lifetime records by Supplement $17 \mathrm{~S}-1$ and Appendix 17A-1 of NQA-1-1989(1) are also lifetime records according to DOE Order 1324.2. ${ }^{(9)}$ 
Records of any major plant modifications or replacements, including associated testing, are accumulated, indexed, and stored using systems consistent with those for the initial plant.

The FFTF FSAR, Chapter 13, Section 13.6, identifies a number of records that are generated during operation, maintenance, and modification. It assigns the responsibility for indexing, keeping, and protecting these records to the organizations generating them until they are no longer of current interest. Records of $Q A$ inspections or other verification will be included with them. Official records of occurrence reports are maintained by Information Resource Management, and $Q A$ audit records are maintained by $Q A$.

Storage and retention requirements for the records are governed by DOE Order 1324.2. ${ }^{(9)}$ The records are put onto microfilm or microfiche with the silver master copies being turned over to the DOE records holding area. Uitimately they are transferred to the Federal Records Center in Seattle. (See Section 16.2.3.15.) 


\subsubsection{AUDITS}

\subsubsection{RESPONSIBILITY}

The QA department is responsible for establishing and implementing the audit program. Other departments furnish engineers and specialists as audit team members.

\subsubsection{PLANNING AND PERFORMANCE}

The QA Audits, both internal and external, shall be planned, prepared, and performed in accordance with WHC-CM-4-2, ${ }^{(3)}$ Section 18.

\subsubsection{REPORTING AND CORRECTIVE ACTION}

At the conclusion of each audit, the findings and supporting observations are reviewed with responsible management. Subsequently, these findings and observations are incorporated into an audit report, which is formally transmitted. Responsible management is required to determine appropriate corrective action and schedules and to periodically report on such actions until complete. Quality Assurance reviews these actions for adequacy and implementation and requests further effort, as needed. Followup audits or other verifications are scheduled, as necessary, to verify the completeness and effectiveness of corrective actions. 


\subsubsection{REFERENCES}

1. ASME Standard NQA-1-1989, Quality Assurance Program Requirements for Nuclear Facilities, American Society of Mechanical Engineers.

2. WHC-CM-1-3, Management Requirements and Procedures, Westinghouse Hanford Company.

3. WHC-CM-4-2, Quality Assurance Manual, Westinghouse Hanford Company.

4. NRC, Title 10, Code of Federal Regulations, "Energy," 10 CFR, Part 50: "Domestic Licensing of Production and Utilization Facilities."

5. WHC-CM-4-8, Quality Assurance Instructions, Westinghouse Hanford Company.

6. ASME Boiler and Pressure Vessel Code, Section XI, American Society of Mechanical Engineers.

7. WHC-CM-4-39, Qualification and Certification of Nondestructive Examination Personnel, Westinghouse Hanford Company.

8. WHC-CM-4-5, Quality Assurance Qualifications and Instructions, Westinghouse Hanford Company.

9. DOE Order 1324.2, Records Disposition.

10. WHC-CM-2-1, Procurement Manual, Westinghouse Hanford Company.

11. WHC-CM-4-28, Quality Assurance Program Manual for ASME Code, Westinghouse Hanford Company.

12. WHC-CM-6-27, Fast Flux Test Facility Engineering Instructions, Westinghouse Hanford Company.

13. WHC-CM-8-4, 400 Area Support Services Manual, Westinghouse Hanford Company.

14. WHC-CM-6-1, Standard Engineering Practices, Westinghouse Hanford Company.

15. WHC-CM-8-8, Job Control System, Westinghouse Hanford Company.

16. HHC-CM-6-4, Hanford Hoisting and Rigging Manual, Westinghouse Hanford Company.

17. HHC-CM-2-14, Hazardous Material Packaging and Shipping, Westinghouse Hanford Company.

18. WHC-IP-0705, Quality Assurance Progran Plan for the Hazardous Materials Transportation and Packaging Program, Westinghouse Hanford Company. 
Table 16.2-1. Cross-Reference of Controlling Documents - Organization.

\begin{tabular}{|c|c|l|c|c|c|c|c|}
\hline $\begin{array}{c}\text { ANSI/ASME } \\
\text { NQA-1 } \\
\text { paragraph }\end{array}$ & $\begin{array}{c}10 \text { CFR 50 } \\
\text { requirement }\end{array}$ & \multicolumn{3}{|c|}{ Requirement } & \multicolumn{5}{|c|}{$\begin{array}{c}\text { Controlling manuals/procedures } \\
\text { (See Section 16.2.2.2) }\end{array}$} \\
\hline BR-1 & $I$ & Purpose & 1 & 12 & 17 & 18 & \\
\hline BR-1 & I & Applicability & QR 1.0 & & & & \\
\hline BR-1 & I & $\begin{array}{l}\text { Responsibility and } \\
\text { authority }\end{array}$ & QR 1.0 & $X$ & $X$ & $X$ & \\
\hline
\end{tabular}


Table 16.2-2. Cross-Reference of Controlling Documents - Quality Assurance Program.

\begin{tabular}{|c|c|c|c|c|c|c|c|c|c|c|c|c|c|c|c|c|}
\hline \multirow{2}{*}{$\begin{array}{c}\text { ANSI/ASME } \\
\text { NQA-1 } \\
\text { paragraph }\end{array}$} & \multirow{2}{*}{$\begin{array}{l}10 \text { CFR } 50 \\
\text { requirenent }\end{array}$} & \multirow{2}{*}{ Requirement } & \multicolumn{14}{|c|}{$\begin{array}{c}\text { Controlling manuals/procedures } \\
\text { (See Section 16.2.2.2) }\end{array}$} \\
\hline & & & 1 & 2 & 5 & $\mathbf{E}$ & 8 & 10 & 12 & 17 & 18 & 19 & 20 & 21 & 22 & 25 \\
\hline BR-2 & 11 & Scope & QR 2.0 & & & & & & $x$ & & & & & & & \\
\hline BR-2 & II & Planning & $\left|\begin{array}{ll}\text { QR } & 2.0 \\
\text { QI } & 2.2\end{array}\right|$ & & & $x$ & & $x$ & $x$ & & & $x$ & & & & \\
\hline BR-2 & 11 & $\begin{array}{l}\text { Training and } \\
\text { indoctrination }\end{array}$ & QR 2.0 & $\left|\begin{array}{ll}\text { QAI } & 2.1 \\
\text { QAI } & 2.2\end{array}\right|$ & $x$ & x. & & & & & & & & $x$ & $x$ & $\operatorname{Sec} 1.0$ \\
\hline BR-2 & II & Personnel qualification & 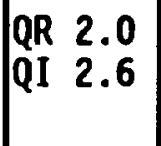 & $\begin{array}{ll}\text { QAI } & 2.1 \\
\text { QAI } & 2.2 \\
\text { QAI } & 2.3\end{array}$ & $x$ & & $x$ & & $x$ & & & & & $x$ & $x$ & $\operatorname{Sec} 1.0$ \\
\hline BR-2 & II & Policies and procedures & 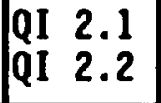 & & & & & & $x$ & & $x$ & & & $x$ & & \\
\hline BR-2 & II & Management review & QI 2.7 & & & & & & $x$ & & & & & & & \\
\hline BR-2 & II & Engineering holds & & & & & & & & & & & EP 1.10 & & & \\
\hline$B R-2$ & II & Occurrence reports & & & & & & & & $x$ & & & & & & \\
\hline
\end{tabular}

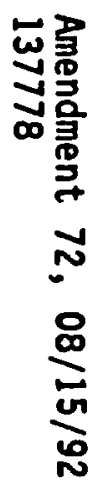


Table 16.2-3. Cross-Reference of Controlling Documents - Design Control.

\begin{tabular}{|c|c|c|c|c|c|c|c|c|c|}
\hline \multirow{2}{*}{$\begin{array}{l}\text { ANSI/ASME } \\
\text { NQA-1 } \\
\text { paragraph }\end{array}$} & \multirow{2}{*}{$\begin{array}{l}10 \text { CFR } 50 \\
\text { requirement }\end{array}$} & \multirow{2}{*}{ Requirement } & \multicolumn{7}{|c|}{$\begin{array}{l}\text { Controlling manuals/procedures } \\
\text { (See Section } 16.2 .2 .2 \text { ) }\end{array}$} \\
\hline & & & 1 & 2 & 3 & 4 & 6 & 12 & 20 \\
\hline$B R-3$ & III & $\begin{array}{l}\text { Controlling and } \\
\text { documenting design }\end{array}$ & QR. 3.0 & & EI-67 & & $x$ & $x$ & $\begin{array}{l}\text { EP } 1.0 \\
\text { EP } 1.1 \\
\text { EP } 1.2 \\
\text { EP } 1.3 \\
\text { EP } 1.5 \\
\text { EP } 1.6 \\
\text { EP } 1.7 \\
\text { EP } 1.11 \\
\text { EP } 2.0 \\
\text { EP } 2.2 \\
\text { EP } 3.3 \\
\text { EP } 5.2\end{array}$ \\
\hline$B R-3$ & III & Design verification & & QAI 3.1 & EI-73 & $x$ & $x$ & $x$ & $\begin{array}{l}\text { EP } 4.1 \\
\text { EP } 4.2\end{array}$ \\
\hline BR-3 & III & Software control & $\begin{array}{lll}\text { QI } & 3.2 \\
\text { QI } & 3.3\end{array}$ & & EI-74 & & & & EP 2.1 \\
\hline
\end{tabular}

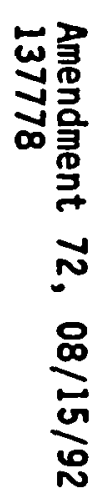


Table 16.2-4. Cross-Reference of Controlling Documents - Procurement Document Control.

\begin{tabular}{|c|c|c|c|c|c|c|c|c|c|}
\hline \multirow{2}{*}{$\begin{array}{c}\text { ANSI/ASME } \\
\text { NQA-1 } \\
\text { paragraph }\end{array}$} & \multirow{2}{*}{$\begin{array}{l}10 \text { CFR } 50 \\
\text { requirement }\end{array}$} & \multirow{2}{*}{ Requirement } & \multicolumn{7}{|c|}{$\begin{array}{l}\text { Controllirg manuals/procedures } \\
\text { (See Section } 16.2 .2 .2 \text { ) }\end{array}$} \\
\hline & & & 1 & 4 & 6 & 9 & 12 & 19 & 20 \\
\hline$B R-4$ & IV & Procurement requirements & $\begin{array}{ll}\text { QR } & 4.0 \\
\text { QI } & 7.5\end{array}$ & $x$ & $x$ & $x$ & $x$ & $x$ & $\begin{array}{ll}\text { EP } & 3.3 \\
\text { EP } & 5.3 \\
\text { EP } & 5.4\end{array}$ \\
\hline BR-4 & IV & $\begin{array}{l}\text { Procurement document } \\
\text { review }\end{array}$ & $\begin{array}{ll}\text { QI } & 4.1 \\
\text { QI } & 4.2\end{array}$ & & $x$ & $x$ & $x$ & $x$ & \\
\hline
\end{tabular}

1
$\vdots$
$\vdots$
$\vdots$
$\vdots$

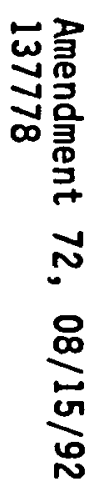


Table 16.2-5. Cross-Reference of Controlling Documents - Instructions, Procedures, and Drawings.

\begin{tabular}{|c|c|c|c|c|c|c|c|c|c|c|}
\hline \multirow{2}{*}{$\begin{array}{l}\text { ANSI/ASME } \\
\text { NQA-1 } \\
\text { paragraph }\end{array}$} & \multirow{2}{*}{$\begin{array}{l}10 \text { CFR } 50 \\
\text { requirement }\end{array}$} & \multirow{2}{*}{ Requirement } & \multicolumn{8}{|c|}{$\begin{array}{c}\text { Controlling manuals/procedures } \\
\text { (See Section 16.2.2.2) }\end{array}$} \\
\hline & & & 1 & 6 & 7 & 12 & 16 & 19 & 20 & 22 \\
\hline BR-5 & v & $\begin{array}{l}\text { Instruction, procedures, } \\
\text { and drawings }\end{array}$ & $\mid \begin{array}{ll}Q R & 5.0 \\
Q I & 5.1\end{array}$ & $x$ & $x$ & $x$ & $x$ & $x$ & $\begin{array}{ll}\text { EP } & 1.1 \\
\text { EP } & 1.2 \\
\text { EP } & 1.3 \\
\text { EP } & 1.12 \\
\text { EP } & 2.0 \\
\text { EP } & 2.1 \\
\text { EP } & 2.2 \\
\text { EP } & 5.1 \\
\text { EP } & 5.6 \\
\text { EP } & 5.8\end{array}$ & $x$ \\
\hline
\end{tabular}

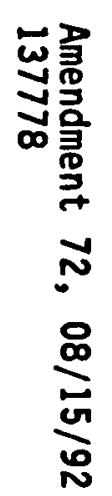


Table 16.2-6. Cross-Reference of Controlling Documents - Document Control.

\begin{tabular}{|c|c|c|c|c|c|c|c|c|c|c|c|}
\hline \multirow{2}{*}{$\begin{array}{c}\text { ANSI/ASME } \\
\text { NQA-1 } \\
\text { paragraph }\end{array}$} & \multirow{2}{*}{$\begin{array}{l}10 \text { CFR } 50 \\
\text { requirenent }\end{array}$} & \multirow{2}{*}{ Requirement } & \multicolumn{9}{|c|}{$\begin{array}{l}\text { Controlling manuals/procedures } \\
\text { (See Section } 16.2 .2 .2 \text { ) }\end{array}$} \\
\hline & & & 1 & 2 & 7 & 12 & 16 & 19 & 20 & 22 & 24 \\
\hline BR-6 & VI & Document control & $\begin{array}{ll}\text { QR } & 6.0 \\
\text { QI } & 6.1\end{array}$ & QAI 6.1 & $x$ & $x$ & $x$ & $x$ & $\begin{array}{ll}\text { EP } & 1.1 \\
\text { EP } & 1.2 \\
\text { EP } & 1.3 \\
\text { EP } & 1.6 \\
\text { EP } & 1.7 \\
\text { EP } & 1.11 \\
\text { EP } & 1.12 \\
\text { EP } & 2.1 \\
\text { EP } & 2.2 \\
\text { EP } & 2.3 \\
\text { EP } & 5.1 \\
\text { EP } & 5.6\end{array}$ & $x$ & $x$ \\
\hline
\end{tabular}


Table 16.2-7. Cross-Reference of Controlling Documents - Control of Purchased Items and Services.

\begin{tabular}{|c|c|c|c|c|c|c|c|c|c|c|c|}
\hline \multirow{2}{*}{$\begin{array}{c}\text { ANSI/ASME } \\
\text { NQA-1 } \\
\text { paragraph }\end{array}$} & \multirow{2}{*}{$\begin{array}{l}10 \text { CFR } 50 \\
\text { requirement }\end{array}$} & \multirow{2}{*}{ Requirement } & \multicolumn{9}{|c|}{$\begin{array}{l}\text { Controll ing manuals/procedures } \\
\text { (See Section } 16.2 .2 .2 \text { ) }\end{array}$} \\
\hline & & & 1 & 2 & 4 & 6 & 9 & 12 & 19 & 20 & 23 \\
\hline BR-7 & VII & $\begin{array}{l}\text { Procurement plan and : } \\
\text { control }\end{array}$ & $\begin{array}{ll}\text { QR } & 7.0 \\
\text { QI } & 7.1 \\
\text { QI } & 7.5\end{array}$ & & $x$ & $x$ & $x$ & $x$ & $x$ & $\begin{array}{ll}\text { EP } & 2.3 \\
\text { EP } & 5.3 \\
\operatorname{EP} & 5.5\end{array}$ & \\
\hline$B R-7$ & VII & Supplier evaluation & QI 7.2 & & & & $x$ & $x$ & & & \\
\hline BR-7 & VII & Source surveillance & 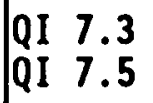 & & & & $x$ & $x$ & & & \\
\hline BR-7 & VII & Receivtng inspection & QI 7.5 & 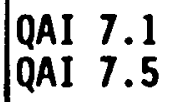 & & & & & & EP 3.3 & $x$ \\
\hline
\end{tabular}


Table 16.2-8. Cross-Reference of Controlling Documents - Identification and Control of Items.

\begin{tabular}{|c|c|c|c|c|c|c|c|c|c|}
\hline \multirow{2}{*}{$\begin{array}{c}\text { ANSI / ASME } \\
\text { NQA-1 } \\
\text { paragraph }\end{array}$} & \multirow{2}{*}{$\begin{array}{l}10 \text { CFR } 50 \\
\text { requirement }\end{array}$} & \multirow{2}{*}{ Requirement } & \multicolumn{7}{|c|}{$\begin{array}{c}\text { Controlling manuals/procedures } \\
\text { (See Section } 16.2 .2 .2 \text { ) }\end{array}$} \\
\hline & & & 1 & 7 & 12 & 18 & 19 & 20 & 23 \\
\hline BR-8 & VIII & $\begin{array}{l}\text { Ident:fication and } \\
\text { control of items }\end{array}$ & $\mid \begin{array}{ll}\text { QR } & 8.0 \\
\text { QI } & 8.1\end{array}$ & $x$ & $x$ & $x$ & $x$ & $\begin{array}{ll}\text { EP } & 1.3 \\
\text { EP } & 5.4 \\
\text { EP } & 5.6\end{array}$ & $x$ \\
\hline
\end{tabular}

$\overrightarrow{1}$
$\vdots$
0
$\vdots$
1
0

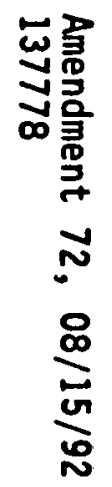


Table 16.2-9. Cross-Reference of Controlling Documents - Control of Processes.

\begin{tabular}{|c|c|c|c|c|c|c|c|c|c|}
\hline \multirow{2}{*}{$\begin{array}{c}\text { ANSI/ASME } \\
\text { NQA-1 } \\
\text { paragraph }\end{array}$} & \multirow{2}{*}{$\begin{array}{l}10 \text { CFR } 50 \\
\text { requirement }\end{array}$} & \multirow{2}{*}{ Requirement } & \multicolumn{7}{|c|}{$\begin{array}{c}\text { Controlling manuals/procedures } \\
\text { (See Section 16.2.2.2) }\end{array}$} \\
\hline & & & 1 & 5 & 8 & 11 & 12 & 16 & 19 \\
\hline BR-9 & IX & $\begin{array}{l}\text { Fabrication and assembly } \\
\text { processes }\end{array}$ & QI 9.2 & & $x$ & & $x$ & $x$ & $x$ \\
\hline BR-9 & IX & Control of processes & QR 9.0 & & $x$ & & $x$ & $x$ & \\
\hline BR-9 & IX & $\begin{array}{l}\text { Nondestructive } \\
\text { examination }\end{array}$ & QI 9.1 & $x$ & & $x$ & $x$ & & \\
\hline BR-9 & IX & Clearing & QR 9.0 & & & & $x$ & & \\
\hline BR-9 & IX & Other special processes & QR 9.0 & & & & & & \\
\hline
\end{tabular}


Table 16.2-10/11. Cross-Reference of Controlling Documents - Inspection and Test Control.

\begin{tabular}{|c|c|c|c|c|c|c|c|c|c|c|c|c|c|}
\hline \multirow{2}{*}{$\begin{array}{c}\text { ANSI/ASME } \\
\text { NQA-1 } \\
\text { paragraph }\end{array}$} & \multirow{2}{*}{$\begin{array}{l}10 \text { CFR } 50 \\
\text { requi rement }\end{array}$} & \multirow{2}{*}{ Requirement } & \multicolumn{11}{|c|}{$\begin{array}{l}\text { Controlling manuals/procedures } \\
\text { (See Section 16.2.2.2) }\end{array}$} \\
\hline & & & 1 & 2 & 3 & 4 & 6 & 11 & 12 & 14 & 15 & 19 & 20 \\
\hline BR-10/BR-11 & $X, X I$ & General requirements & $\begin{array}{ll}Q R & 10.0 \\
Q R & 11.0\end{array} \mid$ & & EI-93 & & $x$ & & $x$ & & & & $\begin{array}{l}\text { EP } 2.1 \\
\text { EP } 4.2\end{array}$ \\
\hline BR-10/BR-11 & $X, X I$ & $\begin{array}{l}\text { Inspection and test } \\
\text { procedures }\end{array}$ & $\left|\begin{array}{ll}\text { QR } & 10.0 \\
\text { QR } & 11.0\end{array}\right|$ & & $\begin{array}{l}\text { EI }-94 \\
\text { EI }-1014\end{array}$ & & $x$ & $x$ & $x$ & & & & $\begin{array}{ll}\text { EP } & 4.2 \\
\text { EP } & 5.8\end{array}$ \\
\hline BR-10/BR-11 & $X, X I$ & $\begin{array}{l}\text { Inspection and test } \\
\text { planning }\end{array}$ & $\mid \begin{array}{ll}\text { QR } & 10.0 \\
\text { QI } & 10.2 \\
\text { QI } & 10.5 \\
\text { QR } & 11.0\end{array}$ & $\left|\begin{array}{ll}\text { QAI } & 10.1 \\
\text { QAI } & 11.1\end{array}\right|$ & & & $x$ & & $x$ & $x$ & $x$ & $x$ & EP 4.2 \\
\hline BR-10/BR-11 & $X, X I$ & $\begin{array}{l}\text { Completed item } \\
\text { inspection and test }\end{array}$ & $\left|\begin{array}{ll}Q I & 10.1 \\
Q I & 10.2 \\
Q R & 11.0\end{array}\right|$ & QAI 11.1 & EI-95 & $x$ & $x$ & & $x$ & $x$ & & & \\
\hline Surve 111 ance & & & $\left|\begin{array}{ll}\text { QI } & 10.4 \\
\text { QI } & 10.5\end{array}\right|$ & & & & & & & & & & \\
\hline $\begin{array}{l}\text { Stamp } \\
\text { control }\end{array}$ & & & & QAI 10.3 & & & & & & & & & \\
\hline
\end{tabular}

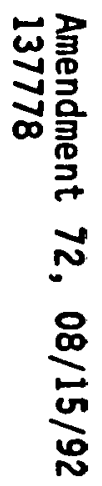


Table 16.2-12. Cross-Reference of Controlling Documents - Control of Measuring and Test Equipment.

\begin{tabular}{|c|c|c|c|c|c|c|c|}
\hline \multirow{2}{*}{$\begin{array}{l}\text { ANSI /ASME } \\
\text { NQA-1 } \\
\text { paragraph }\end{array}$} & \multirow{2}{*}{$\begin{array}{l}10 \text { CFR } 50 \\
\text { requirement }\end{array}$} & \multirow{2}{*}{ Requirement } & \multicolumn{5}{|c|}{$\begin{array}{l}\text { Controlling manuals/procedures } \\
\text { (See Section } 16.2 .2 .2 \text { ) }\end{array}$} \\
\hline & & & 1 & 3 & 7 & 12 & \\
\hline BR-12 & $X I I$ & $\begin{array}{l}\text { Measuring and test } \\
\text { equipment cal ibration } \\
\text { and control }\end{array}$ & $\begin{array}{ll}\text { QR } & 12.0 \\
Q I & 12.1 \\
Q I & 12.2 \\
Q I & 12.3\end{array}$ & EI-68 & $x$ & $x$ & \\
\hline
\end{tabular}

1
$\frac{1}{0}$
$\vdots$
$\vdots$
$=$

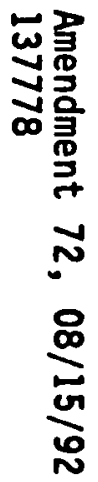


Table 16.2-13. Cross-Reference of Controlling Documents - Handling, Storage, and Shipping.

\begin{tabular}{|c|c|c|c|c|c|c|c|c|c|c|c|c|c|}
\hline \multirow{2}{*}{$\begin{array}{c}\text { ANSI/ASME } \\
\text { NQA-1 } \\
\text { paragraph }\end{array}$} & \multirow{2}{*}{$\begin{array}{l}10 \text { CFR } 50 \\
\text { requitrement }\end{array}$} & \multirow{2}{*}{ Requirement } & \multicolumn{11}{|c|}{$\begin{array}{c}\text { Controlling manuals/procedures } \\
\text { (See Section 16.2.2.2) }\end{array}$} \\
\hline & & & 1 & 2 & 6 & 12 & 14 & 15 & 19 & 20 & 23 & 26 & 27 \\
\hline BR-13 & XIII & Handling & QI. 13.3 & QAI 13.1 & $x$ & $x$ & $x$ & $x$ & $x$ & EP 1.2 & $x$ & $\bar{x}$ & $x$ \\
\hline$B R-13$ & $X I I I$ & $\begin{array}{l}\text { Preservation, packaging, } \\
\text { and storage }\end{array}$ & QR 13.0 & QAI 13.2 & & $x$ & $x$ & $x$ & $x$ & EP 5.5 & $x$ & $x$ & $x$ \\
\hline$B R-13$ & $X I I I$ & Shipping & QR 13.0 & & & & $x$ & $x$ & & EP 5.5 & $x$ & $x$ & $x$ \\
\hline
\end{tabular}

1
1
0
1
$n$

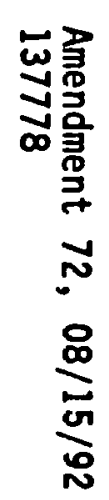


Table 16.2-14. Cross-Reference of Controlling Documents - Operating Status.

\begin{tabular}{|c|c|c|c|c|c|c|c|}
\hline $\begin{array}{c}\text { ANSI/ASME } \\
\text { NQA-1 } \\
\text { paragraph }\end{array}$ & $\begin{array}{c}10 \text { CFR 50 } \\
\text { requirement }\end{array}$ & \multicolumn{2}{|c|}{ Requirement } & \multicolumn{4}{|c|}{$\begin{array}{c}\text { Controlling manuals/procedures } \\
\text { (See Section 16.2.2.2) }\end{array}$} \\
\hline BR-14 & XIV & $\begin{array}{l}\text { Inspection, test and } \\
\text { operating status }\end{array}$ & $\begin{array}{l}\text { QR } 14.0 \\
\text { QI } 14.1\end{array}$ & $x$ & $X$ & $X$ & \\
\hline
\end{tabular}

-1
$\frac{1}{0}$
1
1
$\omega$ 
Table 16.2-15. Cross-Reference of Controlling Documents - Control of Nonconfarming Items.

\begin{tabular}{|c|c|c|c|c|c|c|c|c|c|}
\hline \multirow{2}{*}{$\begin{array}{c}\text { ANSI/ASME } \\
\text { NQA-I } \\
\text { paragraph }\end{array}$} & \multirow{2}{*}{$\begin{array}{l}10 \text { CFR } 50 \\
\text { requirement }\end{array}$} & \multirow{2}{*}{ Pequirement } & \multicolumn{7}{|c|}{$\begin{array}{c}\text { Controlling manuals/procedures } \\
\text { (See Section 16.2.2.2) }\end{array}$} \\
\hline & & & 1 & 3 & 4 & 6 & 12 & 19 & \\
\hline BR-15 & $X V$ & $\begin{array}{l}\text { Control of nonconforming } \\
\text { items }\end{array}$ & $\begin{array}{ll}\text { QR } & 15.0 \\
Q I & 15.1 \\
Q I & 15.2\end{array}$ & $E 1-80$ & $x$ & $x$ & $x$ & $x$ & \\
\hline
\end{tabular}


Table 16.2-16. Cross-Reference of Controlling Documents - Corrective Action.

\begin{tabular}{|c|c|c|c|c|c|c|c|}
\hline \multirow{2}{*}{$\begin{array}{c}\text { ANSI/ASME } \\
\text { NQA-1 } \\
\text { paragraph }\end{array}$} & \multirow{2}{*}{$\begin{array}{l}10 \text { CFR } 50 \\
\text { requirement }\end{array}$} & \multirow{2}{*}{ Requirement } & \multicolumn{5}{|c|}{$\begin{array}{c}\text { Controlling manuals/procedures } \\
\text { (See Section } 16.2 .2 .2 \text { ) }\end{array}$} \\
\hline & & & 1 & 10 & 12 & 17 & \\
\hline BR-16 & XVI & Corrective action & $\left|\begin{array}{ll}Q R & 16.0 \\
Q I & 16.1 \\
Q I & 16.2\end{array}\right|$ & $x$ & $x$ & $x$ & \\
\hline
\end{tabular}

1
$\frac{1}{\sigma}$
1
1
v

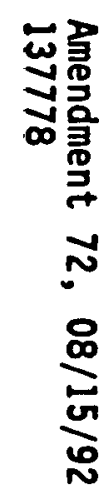


Table 16.2-17. Cross-Reference of Controlling Documents - Quality Records.

\begin{tabular}{|c|c|c|c|c|c|c|c|c|c|c|c|c|c|c|}
\hline \multirow{2}{*}{$\begin{array}{c}\text { ANSI / ASME } \\
\text { NQA-1 } \\
\text { paragraph }\end{array}$} & \multirow{2}{*}{$\begin{array}{l}10 \text { CFR } 50 \\
\text { requirement }\end{array}$} & \multirow{2}{*}{ Requirement } & \multicolumn{12}{|c|}{$\begin{array}{c}\text { Controlling manuals/procedures } \\
\text { (See Section 16.2.2.2) }\end{array}$} \\
\hline & & & 1 & 3 & 6 & 12 & 14 & 15 & 16 & 18 & 19 & 20 & 24 & 26 \\
\hline BR-17 & XVII & Quality records & $\left|\begin{array}{ll}Q R & 17.0 \\
Q I & 17.1\end{array}\right|$ & $x$ & $x$ & $\boldsymbol{x}$ & $x$ & $x$ & $x$ & $x$ & $x$ & EP 1.14 & $x$ & $x$ \\
\hline
\end{tabular}

+1
$\frac{1}{\sigma}$
$\dot{1}$
$\frac{1}{\sigma}$

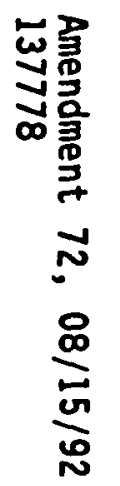


Table 16.2-18. Cross-Reference of Controlling Documents - Audits.

\begin{tabular}{|c|c|l|c|c|c|c|}
\hline $\begin{array}{c}\text { ANSI/ASME } \\
\text { NQA-1 } \\
\text { paragraph }\end{array}$ & \multirow{2}{*}{$\begin{array}{c}10 \text { CFR 50 } \\
\text { requirement }\end{array}$} & \multicolumn{4}{|c|}{ Requirement } & \multicolumn{4}{|c|}{$\begin{array}{c}\text { Controll ing manual s/procedures } \\
\text { (See Section 16.2.2.2) }\end{array}$} \\
\cline { 4 - 8 } & & 1 & 2 & 6 & \\
\hline BR-18 & XVIII & Audits & QR 18.0 & QAI 18.1 & $X$ & \\
QI 18.1 & & & & \\
\hline
\end{tabular}

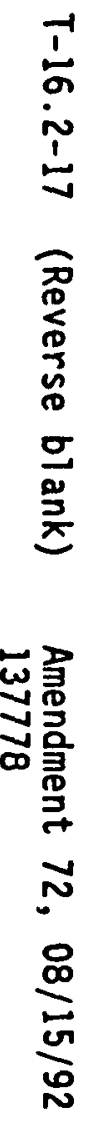




\section{CONTENTS (Cont'd)}

\section{LIMITS}

17.3.0.2 Declaring Equipment INOPERABLE

\begin{tabular}{|c|c|}
\hline evel 1 $1^{*}$ & Page \\
\hline all & $17-29$ \\
\hline al1 & $17-29$ \\
\hline all & $17-30$ \\
\hline al1 & $17-31$ \\
\hline & $17-32$ \\
\hline a) & $17-32$ \\
\hline all & $17-32$ \\
\hline all & $17-33$ \\
\hline --- & $17-34$ \\
\hline$a, b$ & $17-34$ \\
\hline --- & $17-39$ \\
\hline all & $17-43$ \\
\hline all & $17-45$ \\
\hline --- & $17-47$ \\
\hline$a, b$ & $17-50$ \\
\hline-- & $17-52$ \\
\hline--- & $17-53$ \\
\hline- & $17-54$ \\
\hline--- & $17-55$ \\
\hline all & -57 \\
\hline
\end{tabular}

17.3.0.3 Removing Equipment from Service

17.3.0.4 Action Statements for REACTOR SHUTDOWN

17.3.0.5 LCO Format

$17-32$

17.4.0 Surveillance Requirements

17.4.0.1 Performance of Surveillance Requirements

17.4.0.2 Surveillance for Entry into an OPERATIONAL MODE

17.4.0.3 Surveillance for FULL POWER

17.3/4.1 Reactor

17.3/4.1.1 Operation

17.3/4.1.2 Core Loading Characteristics

17.3/4.1.3 Shutdown Reactivity and Rod Worth

17.3/4.1.4 Reactor Stability

17.3/4.1.5. Reactivity Anomalies

17.3/4.1.6 Rod Withdrawal and Drop Time

17.3/4.1.7 Control Rod Configuration

17.3/4.1.8 Control Rod Malfunctions

17.3/4.1.9 (Deleted)

17.3/4.1.10 Instrument Trees

$1 \% .3 / 4.1 .11$ (Deleted)

17.3/4.1.12 In-Vessel Hardware

17.3/4.1.13 SHIMMED CONFIGURATION Operation

a11

$17-57$

*See page iii. 


\section{CONTENTS (Cont'd)}

\section{$\underline{\text { LIMITS }}$}

17.3/4.2 Reactor Heat Transport System

\begin{tabular}{|c|c|}
\hline Level $1^{\star}$ & Page \\
\hline-- & $17-63$ \\
\hline a & $17-63$ \\
\hline -.- & $17-67$ \\
\hline $\begin{array}{c}\text { b. } 2 \text { thru } \\
\text { b. } 4\end{array}$ & $17-70$ \\
\hline--- & $17-75$ \\
\hline all & $17-76$ \\
\hline$a, b, c .7$ & $17-79$ \\
\hline$b, c, d$ & $17-87$ \\
\hline all & $17-96$ \\
\hline & $17-9$ \\
\hline
\end{tabular}

17.3/4.2.10 Primary Cover Gas Equalization

$$
\text { Lines }
$$

17.3/4.2.1 Components and Piping

17.3/4.2.2 Thermal Transients

17.3/4.2.3 System Configuration

17.3/4.2.4 Sodium Plugging Temperature

17.3/4.2.5 Sodium Leakage

17.3/4.2.6 Sodium Inventory Control

17.3/4.2.7 Dump Heat Exchangers

17.3/4.2.8 Primary Pump Coastdown Duration

17.3/4.2.9 HTS Freeze Vent and Freeze Seal Backup Valves

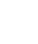

17.3/4.2.11 Pressure Transients

$17.3 / 4.3$ Instrumentation

17.3/4.3.1 Reactor Shutdown System Instrumentation

17.3/4.3.2 Containment Isolation System Instrumentation

17.3/4.3.3 Post-Accident Monitoring Instrumentation

17.3/4.3.4 Monitoring Instrumentation

\section{3/4.3.4.1 Radiation Monitoring} Instrumentation

17.3/4.3.4.2 In-Vessel Flux Monitoring System Instrumentation

17.3/4.3.4.3 Sodium Leak Detection Instrumentation

17.3/4.3.4.4 HTS Monitoring Instrumentation

$\begin{array}{cr}\text { a11 } & 17-100 \\ --- & 17-102 \\ --- & 17-105 \\ --- & 17-105 \\ --- & 17-109 \\ \text { a11 } & 17-111 \\ --- & 17-113 \\ \text { a11 } & 17-113 \\ -- & 17-116 \\ -- & 17-118 \\ --- & 17-122\end{array}$

*See page iii. 


\subsubsection{OPERABLE/INOPERABLE, OPERABILITY}

A system, subsystem, train, component, or device shall be considered OPERABLE or as having OPERABILITY when it is capable of performing its specified function(s); it is INOPERABLE when it is not capable of performing its specified function(s). Implicit in this definition shall be the assumptions that trip points are within the Technical Specifications and that all necessary attendant instrumentation, alarms, controls, electric power, cooling or seal fluids, lubrication; or other auxiliary equipment required for the system, subsystem, train, component, or device to perform its specified function(s) are also capable of performing their related support function(s). Criteria for system OPERABILITY in terms of specific equipment, instrumentation, and/or parameters may be prescribed in appropriate system compliance procedures. 
17.1.22 OPERABLE/INOPERABLE, OPERABILITY (cont'd)

OPERABLE/INOPERABLE FOR DECAY HEAT REMOVAL

A specific OPERABILITY condition referring to the status of nonisolated DHX modules only (i.e., both isolation valves are open). Requirements to satisfy these conditions are given in Section 17.3.2.7.d LCO and are amplified in the related Technical Specifications Compliance Procedures (SC).

\subsubsection{OPERATING}

A system, subsystem, train, component, or device shall be considered OPERATING when it is OPERABLE and is performing its specified function(s).

17.1.24 OPERATIONAL MODE, MODE

The reactor plant conditions as specified in Table 17.1-2.

\subsubsection{REACTOR SHUTDOWN}

The sequence of operations in which the reactor is taken to subcritical condition using normal plant procedures (power reduced with flow kept constant), the primary and secondary rods are inserted, and all scram breakers are opened. For the applicability of Specifications 17.3.4.1, CONTAINMENT INTEGRITY, and 17.3.6.2, ON-SITE IE POWER DISTRIBUTION, REACTOR SHUTDOWN, is the point where subcritical conditions are reached using normal plant procedures.

\section{ALTERNATE REACTOR SHUTDOWN}

The sequence of operations in which the reactor is taken to subcritical condition using a plant procedure where power and flow are reduced on a 1-to-1 ratio between $100 \%$ and $75 \%$ power, the primary and secondary rods are inserted, and all scram breakers are open. 


\subsubsection{REACTOR STARTUP}

The normal procedural sequence of operations in which the reactor is brought from a subcritical condition to a predetermined power.

\subsubsection{RESPONSE TIME (Containment Isolation System)}

The time interval from when the monitored parameter exceeds its actuation point at the output of the channel sensor until opening of the CIS valve breakers.

\subsubsection{SAFETY REVIEW}

An ENGINEERING REVIEW with an independent review and approval by WHC Safety, conducted as defined in the Engineering Administrative Instructions.

\subsubsection{SCRAM RELEASE TIME}

The time interval from when the current to the scram breakers just begins to decrease until the control rod segment arms collapse. This includes delays in the UV trip devices, scram breakers, and CRDMs.

\subsubsection{SHIMMED HEIGHT, SHIMMED CONFIGURATION}

The SHIMMED HEIGHT is that banked height of the primary control rods, which is less than 36 in. withdrawn, at which the primary control rods satisfy the full-out ARPI interlocks. Operation in the SHIMMED CONFIGURATION is controlled by Technical Specification 17.3/4.1.13.

\subsubsection{VERIFY, VERIFICATION}

To confirm or substantiate that a plant condition exists and, if not in this condition, to place the plant in the specified condition. 


\section{$17.3 / 4.5$ PLANT SYSTEMS}

\section{3/4.5.6 PRESSURE RELIEF PATHS}

\section{LIMITS}

\section{ACTION (Cont'd)}

MODES 3 \& 4:

- With no primary HTS relief paths OPERABLE at any one location, terminate in-vessel component handling operations or if the primary pumps are OPERATING, transfer to pony motors until an alternate relief path is established. If there are no OPERABLE relief paths in a secondary loop, the secondary HTS pump shall be transferred to pony motor until an alternate relief path is established.

- With less than the minimum number of relief paths OPERABLE for the containment vacuum relief system, place the plant in a condition not requiring CONTAINMENT INTEGRITY and maintain it in this condition until an alternate relief path is established.

\section{4 .5 .6 SURVEILLANCE REQUIREMENTS}

a. A prcssure relief path shall be declared INOPERABLE for any of the following reasons:

a.1 A pressure or vacuum relief valve actuation lift point is not met and the valve is not or cannot be blocked open or removed (excluding vacuum relief valves).

a.2 The rupture disc between an operable pressure relief valve and the sodium system is not intact. 


\section{$17.3 / 4.5$ PLANT SYSTEMS}

\section{$17.3 / 4.5 .6$ PRESSURE RELIEF PATHS}

\section{LIMITS}

\subsubsection{SURVEILLANCE REQUIREMENTS (Cont'd)}

a.3 The block valve in the relief line is not fully open.

a.4 The heat trace portion of the relief path falls below $300^{\circ} \mathrm{F}$ for more than $48 \mathrm{~h}$, while the HTS sodium temperature is $\geq 450^{\circ} \mathrm{F}$.

b. Each pressure relief valve shall be demonstrated to be OPERABLE every 2 yr within the lift settings shown on Table 17.2.2-2. They shall be checked on a rotating basis such that one valve of each pair is tested on a yearly basis. Each vacuum relief valve shall be demonstrated to be OPERABLE on a quarterly basis within the lift settings shown on Table 17.2.2-4.

c. The following shall be VERIFIED at the specified surveillance intervals.

c.l The blocking valve for each primary pressure relief is open (monthly).

c.2 The interlock allowing closure of only one primary pressure relief blocking valve at a time is OPERABLE (every $2 \mathrm{yr}$ ).

c.3 The blocking valve for each secondary pressure relief is locked open (before the initial REACTOR STARTUP for each CYCLE and for each valve following its operation).

c.4 The rupture disc in each relief line is intact (every $2 \mathrm{yr}$ ).

d. Additionally, trace heat temperatures on the pressure relief path lines shall be MONITORED daily while the HTS sodium temperature is $\geq 450{ }^{\circ} \mathrm{F}$. 


\section{3/4.6.2 ONSITE IE POWER DISTRIBUTION}

Table 17.3.6-3 IE-Related Technical Specifications.

(sheet 2 of 2)

\begin{tabular}{|c|c|c|}
\hline $\begin{array}{l}\text { Inoperable IE } \\
\text { power source }\end{array}$ & Loads rendered inoperable & $\begin{array}{l}\text { Related technical } \\
\text { specification }\end{array}$ \\
\hline \multirow[t]{2}{*}{ Inverter $\mathrm{D} 42$} & $\begin{array}{l}\text { C-127B: } \\
\text { PAM Containment temperature (TI-69015) } \\
\text { PAM Containment pressure (PI-69016) } \\
\text { PAM IDS Vessel temperature (TI-04062) }\end{array}$ & $\begin{array}{l}17 \cdot 3 / 4 \cdot 3 \cdot 3 \\
17 \cdot 3 / 4 \cdot 3 \cdot 3 \\
17 \cdot 3 / 4 \cdot 3 \cdot 3\end{array}$ \\
\hline & $\begin{array}{l}\text { C-181B: } \\
\text { PAM DHX Modules } 3 \text { \& } 4^{\circ} \text { Outlet } \\
\text { temperature, al1 loops (TI-2X521D, } \\
\text { TI-2X528D) } \\
\text { PAM Primary cold leg temperature } \\
\text { Channel BP on each loop (TI-2X008BP) } \\
\text { PAM Reactor outlet plenum temperature } \\
\text { (TI-10314BP) }\end{array}$ & $\begin{array}{l}17.3 / 4.2 .3 \\
17.3 / 4.2 .7 \\
17.3 / 4.3 .3 \\
17.3 / 4.3 .3 \\
17.3 / 4.3 .3\end{array}$ \\
\hline \multirow[t]{3}{*}{ Inverter $\mathrm{D} 43$} & $\begin{array}{l}\text { C-15BP: } \\
\text { Ex-vessel flux monitor }(\mathrm{JI}-10631 \mathrm{~B})\end{array}$ & $17.3 / 4.3 .3$ \\
\hline & $\frac{C-181 B}{D H X F C D}$, Loops $2 \& 3$, Modules $3 \& 4^{\circ}$ & $\begin{array}{l}17.3 / 4.2 .3 \\
17.3 / 4.2 .7\end{array}$ \\
\hline & $\begin{array}{l}\text { C-177B: } \\
\text { PAM Containment high-range gamma } \\
\text { (RISH-83028B) } \\
\text { Control room area radiation monitor } \\
\text { (RISH-96086B) }\end{array}$ & $\begin{array}{l}17.3 / 4 \cdot 3 \cdot 3 \\
17 \cdot 3 / 4 \cdot 3 \cdot 4 \cdot 5\end{array}$ \\
\hline \multirow[t]{2}{*}{$\begin{array}{l}\text { Battery } 02 \text { or } \\
\text { Bus D7 }\end{array}$} & $\begin{array}{l}\text { A11 items } 1 \text { isted above for } \\
\text { Inverters } 042 \text { and } 043\end{array}$ & See Above \\
\hline & $\begin{array}{l}\text { DHX CCD, All loops, Modules } 3 \& 4^{a} \\
\text { ICCW CIS Valves powered from } \\
\text { MCC D39 } \\
\text { Switchgear H-3 tripping control power }\end{array}$ & $\begin{array}{l}17.3 / 4.2 .3 \\
17.3 / 4.2 .7 \\
17.3 / 4.4 .2 \\
17.3 / 4.4 .3 \\
17.2 \cdot 2 \cdot 1\end{array}$ \\
\hline $2 T 0 \quad 015$ & $\begin{array}{l}\text { DHX CCD Buffer, all loops, } \\
\text { Modules } 3 \& 4^{a} \\
\text { PPS Logic train \#2 (will result in a } \\
\text { scram if } 2 T 0 \text { output falls bolow } \\
\text { about } 90 \text { Vac) } \\
\text { Post-scram flux monitor, Channel B }\end{array}$ & $\begin{array}{l}17.3 / 4.2 .7 \\
17.2 .2 .1 \\
17.3 / 4.3 .3\end{array}$ \\
\hline
\end{tabular}

For each loop, Modules $1 \& 2$ are the two lowest numbered modules and Modules 3 \& 4 are the two highest numbered modules.

Only rendered INOPERABLE on a complete loss of battery power. 


\section{$17.3 / 4.6$ ELECTRICAL POWER SYSTEMS}

\section{3/4.6.2 ONSITE IE POWER DISTRIBUTION}

\section{LIMITS}

\subsubsection{SURVEILLANCE REOUIREMENTS}

\section{INVERTER OPERABILITY}

The inverters shall be determined to be OPERATING by MONITORING for correct. breaker alignment and indicated power availability.

\section{INVERTER LOAD-CARRYING ABILITY}

The capability of the inverters shall be VERIFIED by having them provide power for postaccident monitoring and control for a minimum of $1 \mathrm{~h}$ during each refueling or maintenance shutdown (required at least once every 125 days or once per CYCLE, whichever is the longer period).

\section{BATTERY CAPACITY MEASUREMENT}

Battery capacity equal to or greater than 688 amp-h (Ah)(80\%) shall be VERIFIED every $5 \mathrm{yr}$ by performing a test discharge at the 8-h rate to a battery terminal voltage of $105 \mathrm{~V} D C$ or a low individual cell voltage limit of $1.51 \vee D C$. If the capacity is $<100 \%$ ( $860 \mathrm{Ah}$ ) of rated battery $8-h$ capacity, but greater than or equal to 90\% ( $774 \mathrm{Ah}$ ), an ENGINEERING REVIEW shall be conducted to determine if the period between tests should be shortened.

If the capacity is $<90 \%$ ( $774 \mathrm{Ah}$ ) of rated battery 8-h capacity, the test shall be conducted annually. If the annual test falls due during an operating period (MODE 1 or MODE 2), a 3-month grace period is allowed in which to perform the test.

If the capacity is $80 \%$ (688 Ah) or less following the test discharge at the 8-h rate, the battery will be INOPERABLE. 


\section{$17.3 / 4.9$ EXPERIMENTS}

\section{3/4.9.1 OPEN TEST ASSEMBLIES}

\section{LIMITS}

\subsubsection{LIMITING CONDITIONS (Cont'd)}

c. The cumulative total effect of thermal transients of the PIOTAs shall not exceed that for the transients specified in Table 17.3.9-1.

APPLICABILITY: MODES 1 and 2

$\underline{\text { ACTION }}$

a.1, If the conditions cannot be met (by analysis), REACTOR STARTUP shall

a.4, not be initiated. If during reactor operation the previous

$\&$ analysis is judged to be incorrect and the limits are not being met

a.5 (either by re-analysis or review of operating data by the engineering organization), a REACTOR SHUTDOWN shall be initiated to restore temperatures to within the specified limits and a SAFETY ${ }^{--}$ REVIEW shall be performed.

a.2, Perform a REACTOR SHUTDOWN unless Specifications a.2, a.3, and $c$ are a.3, $\& \mathrm{C}$ met. 


\subsection{DESIGN FEATURES}

17.5.1 SITE

\subsubsection{SITE BOUNDARY}

The minumum distance from the reactor centerline to the DOE Hanford Site boundary is 4.5 miles.

17.5.1.2 FLOOD CONTROL

The $p l a n t$ site has been selected to eliminate flooding as a credible event. The bottom of the containment is approximately 83 feet above maximum probable flood level. 


\subsection{DESIGN FEATURES}

\section{5 .2 CONTAINMENT}

\subsubsection{CONFIGURATION}

The reactor containment is a steel vessel of cylindrical shape with ellipsoidal heads and having the following design features:
a. Nominal inside diameter $=135$ feet 0 inches
b. Nominal inside height $=186$ feet 8 inches
c. Nominal thickness of cylindrical walls $=1-3 / 8$ inch
d. Nominal thickness of top head $=1$ inch
e. Nominal thickness of bottom head $=9 / 16$ inch
f. Net free vnlume* $=1,450,0 n n$ ruhir fept.

\subsubsection{PENETRATIONS}

Penetrations through the containment vessel are designed and shall be maintained in accordance with the original design provisions contained in Chapter 6.

*Net free volume is equal to the total containment gas volume $(1,680,000$ cubic feet) minus the volume of closed, inerted cells. 


\subsection{WESTINGHOUSE HANFORD SAFETY}

An organization capable of performing detailed safety analysis shall be maintained within Westinghouse Hanford in order to provide independent safety reviews and audits of FFTF operations. Westinghouse Hanford Safety shall perform an audit of FFTF operations annually.

\subsection{EXPERIMENT REVIEWS}

Westinghouse Hanford shall conduct an independent review of all EXPERIMENTS and advise the Plant Manager as to their safety. This review shall be conducted before EXPERIMENT insertion into the reactor and shall be a multidisciplinary review with participation by organizations representing at least the following disciplines: engineering, EXPERIMENT assembly, quality assurance, safety analysis, and reactor operations.

\subsection{REACTOR SUBCOUNCIL OF THE SAFETY AND ENVIRONMENTAL ADVISORY COUNCIL}

A council shall be maintained within Westinghouse Hanford to advise the President, Westinghouse Hanford, regarding the safety and prudent operation of the FFTF. This council shall be composed of senior personnel within Westinghouse Hanford and shall have a broad charter to examine any aspect of FFTF operation that they deem desirable. The President, Westinghouse Hanford, or the Plant Manager may solicit the Reactor Subcouncll review whenever they deem it necessary. 


\subsection{QUALITY ASSURANCE}

A QA organization shall be maintained by WHC to provide review and audit of the FFTF Plant Manager's organization for compliance with existing procedures and regulations. As a minimum, this review shall be conducted annually.

\subsubsection{RADIATION PROTECTION}

Radiation protection shall be provided consistent with maintaining exposure within the requirements of DOE Order 5480.11, "Radiation Protection for Occupational Workers."

\subsubsection{SURVEILLANCE AND IN-SERVICE INSPECTION}

A Surveillance and In-Service Inspection (SISI) program shall be established in accordance with DOE-approved WHC-SD-FF-SISI-006 (formerly HEDL-MG-89), FFTF SISI Requirements. 


\section{3/4.4.1 CONTAINMENT INTEGRITY}

BASES

\subsubsection{SURVEILLANCE REQUIREMENTS (Cont'd)}

not a required Technical Specification compliance item since it does not directly affect CONTAINMENT INTEGRITY. It protects the EAL from a pressure buildup that could move the inner door away from its seat with a potential for loss of seal integrity. However, this will not result in a loss of CONTAINMENT INTEGRITY since the outer door and escape hatch must necessarily be closed and sealed under these conditions. Hence the only Technical Specification requirement relates to leakage from the RCB back into the EAL via a stuck-open relief valve.

In addition, a differential pressure switch is provided to operate the interior equalization valve if the pressure within the EAL reaches a differential of 2.7 in. WG.

a.5 The FFTF accident analyses involve computation of doses for a 30-day period following the accident. If containment is maintained for 30 days, the doses shown by these analyses will not be exceeded. Elastomers in the containment pressure boundary have been analyzed to show that they will not degrade within 30 days because of the containment environment. Direct manned access to the seals for verification cannot be ensured for all accident conditions. Therefore, it is imperative that the seals maintain their inflation for 30 days without the requirement for direct manned access. Based on initial testing experience through 1981, a semiannual interval has been established for seal leak rate testing. This interval is sufficient to ensure that the seals provide the required integrity. To provide redundant seals when one door is open, it is necessary that both seal systems on the closed door are capable of maintaining inflation. When not in use, both equipment airlock doors are required to be closed when CONTAINMENT INTEGRITY is required, because a single failure to the seal gas pressure system could deflate both seals on a door. 


\section{$17.3 / 4.4 .1$ CONTAINMENT INTEGRITY}

\section{BASES}

\subsubsection{SURVEILLANCE REQUIREMENTS (Cont'd)}

a.6 When any portion of the containment boundary is modified, CONTAINMENT INTEGRITY may have been lost. A successful Type $A, B$, or $C$ test, as applicable, will ensure that CONTAINMENT INTEGRITY has been maintained.

b. MONITORING the containment atmosphere pressure and temperature once per shift is sufficient due to the fact that a 24 hour per day containment watch is maintained. No credible events are identified that can cause the pressure or temperature limits to be exceeded; therefore, the 24-hour surveillance is judged adequate. Atmospheric temperature is conservative in relation to bulk structural temperatures. Positive pressure in containment can be MONITORED when containment is isolated, but the installed instrumentation cannot MONITOR negative pressure.

MONITORING of negative pressure under conditions of containment isolation is not required because containment is protected from excessive external pressure by two seismically qualified vacuum breakers that actuate at -1.5 in. water gauge (maximum). These penetrations are annually checked for cracking pressure and seat leakage. 


\section{$17.3 / 4.5$ PLANT SYSTEMS}

\section{3/4.5.2 REACTOR HEAD COMPARTMENT AND CENTER ISLAND COOLING}

BASES

\subsubsection{SURVEILLANCE REQUIREMENTS (Cont'd)}

bid The MONITORING of Head temperatures (TE 16039A, TE 16040A and TE 16041A) is specified by administrative procedure to be performed at least every shift (see Note)". This MONITORING interval (considering the alarm systems) has been determined by testing to be acceptable for detecting failure of a Center Island Head heater without violating temperature limits. TEs 16039BA and BB, 16040BA and BB, and 16041BA and BB provide a backup for early detection of heating system failures. The Head temperatures are normally MONITORED on the trace heat system readouts. The Control Room alarm circuit also contains these Head temperature inputs. When warranted by Head or heated gas temperature indications, Head thermocouple independent readings can easily be obtained to confirm OPERABILITY of the detectors and readout/alarm systems.

c. Automatic surveillance for the Head Compartment ambient temperature is provided by TAHL- 88200 on C-404, which measures Head Compartment temperature and alarms at $100^{\circ} \mathrm{F}$. Additional surveillance is provided by E-226 (E-227) fault on C-404 and by MONITORING Head Compartment temperature each shift. Operators may VERIFY the ambient temperatures in the area of the Wide Range Flux monitor preamps with hand-held instruments. If the temperature exceeds $100^{\circ} \mathrm{F}$, or cooling flow is lost, then Head Compartment temperatures are MONITORED every 4 hours.

"NOTE: If the Control Room alarm system is not functional or the Reactor is operating under one of the Action statements, the related temperatures are read and recorded at more frequent intervals to ensure deviating temperatures are detected within the time frames of the Action statements and Bases. 


\section{$17.3 / 4.5 .3$ CONTROL ROOM ENVIRONMENT}

\section{BASES}

\subsubsection{BACKGROUND/DERIVATION OF LIMITS}

a. The rack-mounted PPS and essential control equipment located in the Control Room has been designed to be operated in an ambient temperature range between 40 and $120^{\circ} \mathrm{F}$. For higher or lower temperature operation, the safety functions could be compromised. The ambient temperature range of 45 to $100^{\circ} \mathrm{F}$ for $\mathrm{LCO}$ ensures that the temperatures during performance of the Action statement do not go outside of the PPS design limits. At these temperatures normal, healthy operators can perform the light-duty work associated with implementing the ACTION statement. Relief operators would be provided, as necessary, following the guidance of WHC-CM-4-3 for temperature extremes.

b. The Control Room is to remain habitable for operations personnel whenever required for operation, safe SHUTDOWN, or maintenance of post-SHUTDOWN conditions of the plant. Habitable includes (but is not limited to) IIIdillaining chemical contamination within the toxicity limits of NRC Regulatory Guide 1.78, maintaining the routine occupational radiation dose rates within the 5 rem per year specified in DOE Order 5480.11 and in 10 CFR 20, and maintaining accident radiation doses to a maximum 5 rem per event in accordance with 10 CFR 50, Appendix A, Criterion 19. The instrument setpoints are such that conservative calculations on a bounding set of postulated accidents (FSAR Section 6.4) predict doses and concentrations within the above-listed guidance and design criteria for the Control Room.

c. The requirement for Control Room boundary integrity ensures that the design leakage rate is maintained as specified in FSAR Chapter 6.4 and SDD-21. The leak rate value specified was used in the analysis to 
$17.3 / 4.5$ PLANT SYSTEMS

$17.3 / 4.5 .6$ PRESSURE REL IEF PATHS

BASES

\subsubsection{SURVEILLANCE REQUIREMENTS (Cont'd)}

relief path will be declared inoperable. Re-establishment of preheat and the proper temperature profile will permit returning the relief system to normal service.

Quarterly testing of vacuum relief valves for OPERABILITY is based on IMV-3522 of ASME Section XI. Biennial testing of pressure relief valves for OPERABILITY is based on IMV-3510 of ASME Section XI.

The rupture disc in each relief line is VERIFIED to be intact every $2 \mathrm{yr}$. The blocking valve for each primary pressure relief valve shall be VERIFIED open on a monthly basis by the position indication; the blocking valve for each secondary relief valve shall be VERIFIED locked open before the initial REACTOR STARTUP for each CYCLE. Monthly surveillance of the primary relief line pneumatic-actuated block valves is deemed acceptable, because completely redundant relief paths are provided, the valves are interlocked to ensure that at least one path is available at all times, and the valves assume a safe, fail-open position upon loss of pneumatic pressure. A surveillance period of once per CYCLE, performed before the initial REACTOR STARTUP, and following valve operation is judged adequate for the secondary relief line block valves because they are manual, locked-open valves and the availability of keys to these valves is restricted by procedure. The interlock that allows closure of only one primary pressure relief-blocking valve at a time is VERIFIED OPERABLE every $2 \mathrm{yr}$. Trace heat temperatures on the relief path lines shall be MONITORED once each day. These frequencies are judged adequate to ensure proper performance of these systems. 


\section{$17.3 / 4.5$ PLANT SYSTEMS}

\section{3/4.5.7 OPERATING DECK, CENTER ISLAND}

\section{BASES}

\subsubsection{BACKGROUND/DERIVATION OF LIMITS}

a\&b No equipment loads are allowed over the Center Island (CI) region of the Head Compartment Operating Deck during power operation (MODES 1 and 2). Since the most severe loads could not be identified, enveloping calculations were not performed to evaluate consequences of drop-loads. It is permissible to move the unloaded polar gantry crane 200-ton or 20-ton hook over the CI during MODES 1 and 2, provided that the bottom of the hook is no more than $30 \mathrm{ft}$ above the deck. Note that, for purposes of this specification, the bottom of the 200-T crane hook shall be interpreted to include the cheek plates with the attached shackle. Calculations have shown that the unloaded 200-T crane hook with attached cheek plates and shackle can undergo a brake failure, drop from $30 \mathrm{ft}$, and not exceed the structural capacity of the Center Island deck to protect the control rod drives and PPS channels. The only restraining effect that was considered was the rotational inertia of the drum. Free fall, resulting from failure of the hoist rope, was not considered credible. Since the rope has a safety factor of 5 for a fully loaded design lift, the probability that it would fail while unloaded is extremely small. Rope failure, as a consequence of unrestrained "twoblocking" of the hook due to failure of the two upper limit stop microswitches, is precluded by limiting the allowable hook height to $30 \mathrm{ft}$ (this is approximately $1 / 2$ the height to the upper limit stop switches). Normal operating procedures restrict the allowable height of the unloaded hook and appendages to a much lower value that can be more readily gauged by the operator on the main deck.

The permissible height for the smaller 20-T hook was not evalualed; lience a conservative $30 \mathrm{ft}$ is applied to this hook also. To ensure the above, the Operating or Refueling CI Shield Plate shall be in place over the CI during power operation. These restrictions are imposed to avoid the consequences of accidental drop-loads in the region of the 


\section{$17.3 / 4.6$ ELECTRICAL POWER SYSTEMS}

\section{3/4.6.2 ONSITE IE POWER DISTRIBUTION}

BASES

ACTION

a. The following Actions are specified in Table 17.3.6-2:

- A REACTOR SHUTDOWN is required when a battery or distribution system is not capable of providing $\mathrm{IE}$ power, since an additional single failure could put the plant into a condition of having no lE power available for control room postaccident decay heat removal control.

- If the ZTOs are not providing AC with the proper specifications, a reactor scram is performed since the PPS may not be OPERABLE. Transients during switching or diesel loading may cause momentary voltage or frequency trips. Implementing the Action statement is not intended for these 1 imited-duration transients, but only for sustained out-oftolerance conditions. If a ZTO is not capable of transfer from AC to DC (a postaccident safety function of the ZTO), operation may continue if the ZTO is placed in DC drive provided the battery charger is OPERATING. This ensures that the ZTO can perform its required safety function. If the ZTO cannot be transferred to DC drive or is otherwise INOPERABLE for DC drive operation, a REACTOR SHUTDOWN is initiated to place the reactor in a condition where the requirements for postaccident decay heat removal are reduced. A fueled assembly that is being gas-cooled by the IEM Cell Sodium Removal System in the downflow cooling mode, or is being processed in the cleaning station, is restored to a configuration that can be cooled without having the SRS CIVs open. This is done to minimize the potential for experimental data loss or fuel pin cladding failure caused by overheating the assembly. As soon as the fueled assembly configuration permits, the SRS penetrations are isolated 


\section{3/4.6.2 ONSITE IE POWER DISTRIBUTION}

BASES

ACTION (Cont'd)

to ensure that CONTAINMENT INTEGRITY is provided. If the CIVs are not closed within 12 hours, returning the plant to a condition not requiring CONTAINMENT INTEGRITY reduces the probability of radiological release to a minimum.

- If a single inverter is INOPERABLE, reactor operation may continue for 24 hours since the ZTO can back up the inverter for up to 4 hours without reducing the capability for the batteries to provide power for the sevenday period. During this period, if $D-41$ (D-43) is INOPERABLE, only 2/4 DHX modules in HTS Loops 2 and 3 are OPERABLE for decay heat removal and $4 / 4$ in HTS LOOp 1 would be OPERABLE for the Engineered Safety Feature (ESF) Control Room manual control of post-accident decay heat removal. If D-40 (D-42) inverter is INOPERABLE, $2 / 4$ modules in HTS Loops 1,2 and 3 are dependent on ZTO for Engineered Safety Feature (ESF) Control Room manual control of decay heat removal. This is judged acceptable since the time period of risk is small; and even with the worst additional single failure in the IE system, two modules in Loop 1 would still be OPERABLE for post-accident decay heat removal. A REACTOR SHUTDOWN is required after 24 hours of INOPERABILITY since 24 hours is judged to be the maximum period that the plant should operate with this reduced safety margin. Loss of a $I E$ inverter also makes the respective Post-Accident Monitors INOPERABLE. Operation with 1 of 2 of each of these functions is acceptable for the 24-hour period (see Section $17.3 / 4.3 .3$ ).

- If a battery charger is INOPERABLE, reactor operation may continue for 24 hours, provided the ZTO is not in DC drive. This is acceptable since the battery drain during this period by the inverter would not result in a significant battery capacity reduction. However, if the 


\section{$17.3 / 4.6$ ELECTRICAL POWER SYSTEMS}

\section{3/4.6.2 ONSITE 1E POWER DISTRIBUTION}

\section{BASES}

\subsubsection{SURVEILLANCE REQUIREMENTS}

\section{Inverter OPERABILITY}

The operators have been provided with several meters at the inverter cabinets as well as a Control Room output voltmeter (C-181) for each of the four inverters. They are MONITORED once per shift. In addition, low output voltage or high inverter temperature, due to the loss of a cooling fan, will alarm in the control Room. The alarm and surveillance are considered adequate assurance of inverter OPERABILITY.

\section{Inverter Load-Carrying Ability}

The purpose of this surveillance is to VERIFY that each inverter can carry its required $c-181$ loads during a postaccident $7-d$ event. Within $4 \mathrm{~h}$ of the start of such an event, the ZTO units are shut down to conserve battery capacity. With the presumption of no other plant $A C$ power being available, there would be no other $A C$ supply than from these $C l$ ass $\mathrm{IE}$ inverters. The necessary reactor and containment instruments would be supplied via C-181 to MONITOR such conditions as contalnment pressure, temperatures, and radiation. The intent of this test is that this surveillance interval is to be done on a nominal frequency of once a CYCLE, where a CYCLE is $~ 120 \mathrm{~d}$. The 1-hour duration VERIFIES that the inverters could handle such loads if a $7-d$ event should occur.

\section{Battery Capacity Measurement}

This test provides a periodic determination of the condition of each cell and the entire battery. The test results will be compared with those of previous tests to predict when the battery must be replaced. 


\section{3/4.6.2 ONSITE 1E POWER DISTRIBUTION}

\section{BASES}

\subsubsection{SURVEILLANCE REQUIREMENTS (Cont'd)}

The rated battery $8-h$ capacity at $77^{\circ} \mathrm{F}$ is 860 amp-h (Ah), but this capacity will reduce with time because of natural cell plate deterioration. The required Technical Specification capacity was chosen to be $600 \mathrm{Ah}$, which is $00 \%$ of the new battery capacity. This $80 \%$ is the value recommended by IEEE-450 (1987). Which is based on the manufacturer's end of $1 \mathrm{ife}$ for the battery.

The test will normally be performed on a 5-yr interval. If the test shows a capacity $290 \%$ ( $774 \mathrm{Ah}$ ) but <100\%, an ENGINEERING REVIEW shall be conducted to determine if the period between tests should be shortened. When the capacity is $<90 \%$, the test shall be conducted annually. This test frequency provides adequate assurance that a battery will be able to supply the required $80 \%$ capacity throughout its installed life. The 688-Ah capacity is in excess of the predicted requirement. This capacity reserve may be partially used to delay REACTOR SHUTDOWN if a charger fails or if operation of the ZTO from DC power is required.

\section{Periodic Battery Checks}

The weekly measurements of float voltage and float current are to obtain a frequent surveillance of each charging system and battery to verify satisfactory operations. The purpose of the monthly measurement of electrolyte level, specific gravity, cell voltage, and temperature for the pilot cells is to obtain battery data to verify that the charging system and overall integrity of the battery are satisfactory. The quarterly measurement of all $60 \mathrm{cells}$ is intended to determine whether a spread is developing in specific gravity and volts-per-cell measurements of the cells. These readings will be evaluated to determine cell 


\section{3/4.7 REFUELING AND FUEL HANDLING}

\section{$17.3 / 4.7 .2$ EX-VESSEL HANDLING}

\section{$17.3 / 4.7 .2 .3$ IEM CELL}

\section{BASES}

bl Decay heat levels for each fueled assembly shall be calculated based on

c. exposure history and decay times. These calculated values are utilized to administratively limit the decay heat permitted for each assembly entering the cell. Also, fuel pins not in assemblies must be included in calculating the total IEM Cell decay heat load (18 kW limit, ref.).

b2. A SAFETY REVIEW is required before processing irradiated METAL FUEL assemblies in order to review the thermal analysis and temperature limits for the assembly to be processed and to preclude the liquefaction of fuel/cladding eutectic mixtures upon a long and total loss of forced cooling. The SAFETY REVIEW should (1) consider the specific liquefaction temperature limit for each assembly and (2) review the thermal analysis for total loss of forced cooling in a closed container to verify that the peak METAL FUEL/cladding temperature does not exceed the limit. For additional background, see BASES Section 17.4.7.2.1.a\&b.

d. Total iodine activity for each fueled assembly shall be calculated based on exposure history and decay times. The calculated values are used to administratively control total iodine inventory in the IEM Cell.

e. An IEM Cell processing work $p l a n$ is judged administratively adequate to effectively preclude mixing METAL and non-METAL FUEL in the same pin container. The IEM Cell work plan defines the sequence of action involving fuel assemblies and fuel pins in the IEM Cell. These plans are reviewed to VERIFY that they preclude mixing METAL and non-METAL FUEL pins together in a pin container. This verification ensures compliance with the Technical Specifications. 


\section{3/4.7 REFUELING AND FUEL HANDLING}

\section{3/4.7.2 EX-VESSEL HANDLING}

\section{3/4.7.2.4 TEST ASSEMBLY CONDITIONING STATION (TACS)}

\section{BASES}

\subsection{BACKGROUND/DERIVATION OF LIMITS}

The FFTF is designed with the capability for up to four CLIRAs to be installed in the core region. Depending on test program requirements, the CLIRAs can be removed from the reactor by the CLEM, transferred to the IEM cell for interim examination, and then held in the TACS Recycle CLIRA Cells to await return to the reactor. Heating, cooling, and argon purge capability are provided for up to three recycled sodium-filled CLIRA units to inert and maintain the duct temperature between 250 and $600^{\circ} \mathrm{F}$. The cells are designed and analyzed for a CLIRA decay heat of 4.5-kW maximum per cell and a 9.0-kW maximum for all three cells (see FSAR Section 11.6.3.1.1).

Up to three new test assemblies can be inerted and preheated simultaneously in the Inert-Preheat Cells. Additionally, efght storage locations are provided in the Radioactive Storage Vault and twelve locations are provided in the New Storage Vault. Each of these locations is designed to accept a 40-ft-long test assembly. To decouple the stored assemblies, the storage vaults use grid spacers to ensure proper geometric spacing under normal conditions. With the normal spacing maintained by the grid spacers, analysis has shown that a maximum $k_{\text {eff }}$ of 0.7 would exist for a situation in which all storage locations are occupied by fueled test assemblies (assuming that each was loaded with fissile material equivalent to a driver fuel assembly) and the vault is flooded with water or Mobiltherm (see FSAR Section 11.6.3.1.1). However, since the grid spacers have not been seismically qualified, the number of stored, fueled assemblies is administratively controlled (see FSAR Section 20.4.1.D.1.4.1). These controls ensure that a criticality cannot occur in either the New or Radioactive Storage Vault, even if the grid spacers fail and stored fuel is fully moderated. 


\section{$17.3 / 4.7$ REFUELING AND FUEL HANDLING}

$17.3 / 4.7 .2$ EX-VESSEL HANDLING

17.3/4.7.2.4 TEST ASSEMBLY CONDITIONING STATION (TACS)

\section{BASES}

\section{APPLICABILITY}

These conditions apply at all times.

\section{ACTION}

With any of the limits exceeded, the action is to bring the TACS back into compliance with the requirement. If an assembly has been inserted and the decay heat limit is exceeded, the assembly shall be removed. If the insertion results in a calculated $k_{\text {eff }} \geq 0.9$, all handling operations shall be suspended. pending a SAFETY REVIEW to determine the proper course of action to take to safely remove the assembly.

\section{4 .7 .2 .4 SURVEILLANCE REQUIREMENTS}

The Detailed Refueling Plan defines movement of test assemblies in and out of the TACS. Before the placement of fueled test assemblies in TACS, analyses shall be made to ensure that decay heat limits and reactivity limits are not exceeded. 


\section{3/4.7 REFUELING AND FUEL HANDLING}

\section{3/4.7.2 EX-VESSEL HANDLING}

\section{3/4.7.2.5 CORE COMPONENT CONDITIONING STATION (CCCS)}

\section{BASES}

\subsection{BACKGROUND/DERIVATION OF LIMITS}

Three CCCS cells are located between the BLTC tracks in the RCB. One is located north of IDS and two are located south of IDS. The north cell and the southmost cell are designed for preheating and inerting of FTR core components and the remaining south cell is designed for use as a transfer cell between CLEM and BLTC. The items transferred would be pin containers or a cleaned core component in a dry CCP. The transfer cell is designed to handle up to $1.0 \mathrm{~kW}$ of decay heat. If cooling is lost when a 1.0-kW assembly is in the transfer cell, the maximum fuel pin cladding temperature would be less than $1500{ }^{\circ} \mathrm{F}$ (non-METAL FUEL) or the liquefaction temperature limit (METAL FUEL).

\section{APPLICABILITY}

These conditions apply specifically at all times when fuel is being handled.

\section{ACTION}

Decay heat loads in the pin containers should not exceed $0.6 \mathrm{~kW}$ since that is the rating for the container. However, if the container were inadvertently loaded with 40 pins from a 5.5-kW assembly (20 to 40-day decay, depending on assembly irradiation power level) it would exceed $1.0-\mathrm{kW}$ decay heat in the pin container. Core components after cleaning in the IEM Cell could exceed 1.0-kW decay heat unless the assembly decay time is on the 


\subsection{FIRE DETECTION/SUPPRESSION: BASES}

\section{BASES}

\subsubsection{FIRE DETECTION AND ALARM SYSTEM}

OPERABILITY of the Fire Detection and Alarm System ensures that adequate warning capability is available for prompt detection of fires. Prompt detection of fires will reduce the potential for damage and is an integral element of the overall Fire Protection Program.

In the event that a portion of the Fire Detection and Alarm System is INOPERABLE, either for scheduled maintenance or because of an unplanned outage, the requirements set forth herein shall be followed.

\subsubsection{FIRE PROTECTION SYSTEMS}

The OPERABILITY of the Fire Protection Systems ensures that adequate fire suppression capability is available to confine and extinguish fires. The Fire Protection System consists of the water system, spray and/or sprinklers, Aqueous Film Forming Foam (AFFF), Halon, fire hose stations, $\mathrm{N}_{2}$ flooding, and penetration fire barriers.

In the event that a Fire Protection System is INOPERABLE either for scheduled maintenance or an unplanned outage, the requirements set forth herein shall be followed. Alternate backup fire fighting equipment may be required until the affected equipment can be restored to service.

In the event that the Fire Water Supply System becomes INOPERABLE, immediate corrective measures must be taken since this system provides the major fire suppression capability for the plant. 


\subsection{FIRE DETECTION/SUPPRESSION: BASES}

\section{BASES}

\subsubsection{PENETRATION FIRE BARRIERS}

The OPERATIONAL integrity of the penetration fire barriers ensures that fires will be confined or adequately retarded from spreading to adjacent portions of the plant, thereby fulfilling the space isolation FIRE AREA BOUNDARY requirements. This design feature minimizes the possibility of a single fire rapidly involving other areas of the plant before detection and extinguishment.

An exception to the requirement allows for access to Cell 402 Pipeway. Access is provided to Cell 402 Pipeway only by removing the fire and smoke damper, which renders the penetration INOPERABLE. This is considered acceptable, providing the fire detection system remains OPERABLE and either an hourly fire watch is maintained to monitor for combustibles in the cell, or a fire retardant cover is installed over the cell opening, secured by at least two bolts. Cell 402 access is outside the HTS buildings and has minimal combustible materials, therefore the possibility of a fire spreading from Cell 402 is remote. 


\section{3/4.2 FIRE PROTECTION SYSTEMS}

\section{3/4.2.6 PENETRATION FIRE BARRIERS}

\section{LIMITS}

\subsubsection{LIMITING CONDITIONS FOR OPERATION}

All penetration fire barriers shall be OPERABLE.

\section{EXCEPTION:}

The fire and smoke damper for Cell 402 HTS Pipeway may be removed from service for cell access provided that:

1. An hourly fire watch is maintained to monitor for the buildup of flammable and combustible materials. The amount of these materials taken into the cell will be limited to only that which is required for the job. All materials will be removed from the cell whenever no personnel are present, or

2. The cell access is blocked by a fire-retardant cover secured by at least two bolts.

APPLICABILITY: All modes.

\section{ACTION}

In the event that a penetration fire barrier becomes INOPERABLE, restore to OPERABLE status within 14 days. If a penetration fire barrier remains INOPERABLE beyond 14 days, prepare and submit a report to the DOE within 10 days, outlining the cause of the malfunction and plans for restoring to OPERABLE status. 


\section{3/4.2.6 PENETRATION FIRE BARRIERS}

\section{LIMITS}

\subsubsection{SURVEILLANCE REQUIREMENTS}

1. Penetration fire barriers shall be verified to be OPERABLE by a visual inspection:

- At least ANNUALLY for all fire doors.

- At least TRIENNIALLY for all fire/smoke dampers, and

- Prior to declaring a penetration fire barrier OPERABLE following new placement, repairs, or maintenance.

2. In addition to verification by visual inspections, fire/smoke dampers shall be verified TRIENNIALLY to be OPERABLE by performance of a CHANNEL FUNCTIONAL TEST. 


\subsection{NUCLEAR SAFETY LIMITS}

The Nuclear Safety Limits are binding for all operations within Buildings 405, 4717, and 403 (FFTF Containment and Reactor Service Buildings and the Fuel Storage Facility). All other information presented is intended to be descriptive of or justification for the Nuclear Safety Limits. Changes in operating conditions from those described in this report that adversely affect safety will receive additional analysis and will require an addendum to or a revision of the appropriate section in this chapter. Such changes are those that increase either the probability or the consequences of a previously analyzed accident, or that introduce the possibility of an accident type not previously considered.

20.3.1 Fissionable Material Operations--shall all be controlled by engineered safeguards and/or procedures such that the twocontingency policy is satisfied. The two-contingency policy states that at least two unlikely, independent and concurrent events must occur before criticality is possible.

20.3.2 Batch Limit--defines the quantity of fissionable material, consisting of one or more items, that is considered as a unit for control purposes.

- The quantity of fissionable material handled as a batch in transfer, process, or storage shall not exceed $45 \%$ of the critical quantity (mass or number). For mixed materials having the same moderation restrictions, the sum of the fractions of the critical mass and/or critical number of each type of material or fuel pin present in a batch shall not exceed 0.45 . On the 550-ft level of the RSB and $R C B$, the quantity of fissionable material handled as a batch in transfer, process, or storage shall be less than one-third of the minimum critical quantity. When fissionable material is securely packaged within a container of high integrity, the geometry restrictions imposed by the container may be taken into account. 
- When geometry, spacing, and/or moderator exclusion is ensured, such geometry, spacing, and/or moderator exclusion may be taken into account in determining the critical mass or critical number. Otherwise, geometry, spacing, and/or moderator shall be assumed to be that providing the smallest critical quantity.

- Batch limits on fuel and moderating materials shall be specified such that overbatching of any or all of the materials to a quantity less than 2.22 times its batch limit could not result in criticality. (Note: $1 / 0.45=2.22$ )

- On the 550-ft level of the RSB and RCB, one of the following shall be met:

- Batches equal to 0.33 minimum critical quantity, but no more than 0.45 of a critical quantity, may be handled on a temporary basis with alarm coverage provided by a portable criticality Alarm System (CAS)

- If.justification is provided by a specific analysis that a criticality is not possible, based on physical form and isotopic distribution of the fissionable material, 0,45 of a minimum critical quantity may be handled as a batch without alarm coverage.

- For batches equal to or less than $33 \%$, no analysis or alarm coverage is required.

20.3.3 Arrays Criteria--shall meet the following criteria:

- Full reflection and optimum interspersed moderation shall be assumed, taking into account the type and physical form of the material permitted. Generally water will be assumed for the reflector and moderator. 
- Arrays shall be established based on the following:

- The number of units shall not exceed $45 \%$ of the critical number when the spacing is ensured by mechanical means. If the limit is based on spacing that is not ensured by mechanical means, the number of units shall not exceed $33 \%$ of the critical number.

- The $k_{\text {eff }}$ of the array under any allowed condition or credible accident conditions shall not exceed 0.95 at the $95 \%$ confidence level. Interaction with other arrays and overbatching errors shall be considered in determining the value of $k_{e f f}$.

- Array geometry shall be limited to $75 \%$ of the critical volume, or $85 \%$ of the critical diameter or critical slab thickness.

20.3.4 Geometry Restrictions for Containers--shall be based on the following:

- When slab geometry control is used and is ensured by mechanical design: the slab thickness shall not exceed $85 \%$ of the minimum critical slab thickness for the type and form of fissionable material allowed.

- When slab geometry control is used, but is not ensured by mechanical design, the slab thickness shall not exceed $33 \%$ of the minimum critical slab thickness.

20.3.5 Spacing Restrictions--One of the following shall apply:

- The spacing between two batches of fissionable material shall be at least $2 \mathrm{ft}$ edge to edge when maintained administratively. 
- The spacing between two batches of fissionable material shall be at least $1 \mathrm{ft}$ edge to edge when maintained by mechanical means; however, a spacing less than $1 \mathrm{ft}$ may be used providing a technical analysis is performed for the operation and the two-contingency policy is satisfied.

- The following fissionable material transfers may be made without regard to spacing between material being moved and material in a fixed location:

- Material may be added or removed from a container when the total does not exceed the batch limit

- A single batch may be entered into or removed from an array.

\subsubsection{Shipping Containers}

- Fissionable materials within shipping containers for which a DOT permit and/or DOE approval has been granted may be received, handled, and stored under the conditions of the permit or approval in lieu of other controls specified in these limits.

\subsubsection{Reflection}

- Full reflection shall be used in setting limits unless it can be assured that a lesser degree of reflection will not be exceeded. Full reflection shall consist of at least 12 inches of close fitting water or Mobiltherm. Concrete reflection shall be used when it is present to such a degree as to provide a better reflector than water or Mobil therm. 


\subsection{CRITICALITY PREVENTION SPECIFICATIONS}

\subsubsection{Criticality Prevention Specifications 405-1, 550-ft Level of RCB and RSB}

Work Location: Reactor Service Building (RSB, BIdg. 4717) and Reactor Containment Building (RCB, Bldg. 405), excluding the IEM Cell.

\section{A. Eissionable Material Description}

1. Fuel Pins--Only fuel pins contained in the assemblies or pin containers specified in Sections A.2 and A.3 below shall be handled.

2. Assemblies

2.1 Type $A$ assemblies.

2.1.1 Driver fuel assemblies consisting of a hexagonal lattice of 217 (max) driver fuel pins with fuel composition as described in Section 20.4.2, Part A.1.1.1, inside a standard duct. The pin lattice has a $0.287-i n$. pitch.

2.1.2 Fuel assemblies, other than driver fuel, that are no more reactive than a driver fuel assembly with fuel composition as shown in Section 20.4.1, Part A.1.

2.2 The following approved Type B assemblies:

\begin{tabular}{lr} 
MFF-2 & Serial Number \\
MFF-3 & 2168 \\
MFF-4 & 2169 \\
MFF-5 & 2088 \\
MFF-6 & 2089 \\
MFF-8A & 2090 \\
\hline
\end{tabular}


All nonreference fuel assemblies (reference fuel assemblies are Series I or Series II fuel assemblies as described in FSAR Chapter 17, Section 17.5.3.1) shall be approved as Type A or B assemblies before handling at the FFTF. A list of approved fuel assemblies shall be maintained by the Criticality Safety Representative and with the Shift Operations Manager's copy of the FSAR, Chapter 20.

A statement will be made on the above list affirming that any combination of approved assemblies loaded in Interim Decay Storage (IDS) would result in an IDS $k_{\text {eff }}<0.95$ at the 2- $\sigma$ confidence level.

\section{Closed Ident 69 and Ident 1578 Pin Containers Containing Fuel Pins}

3.1 Closed Ident 1578 pin containers containing Type A fuel pins.

3.2 Closed Ident 69 pin containers containing no more than 217 Type A fuel pins.

3.3 Closed. Ident 1578 and Closed Ident 69 pin containers containing any Type $B$ fuel pins where the pin container loading has been approved and found to be no more reactive than a Type $A$ assembly when unmoderated and greater than three pin containers are necessary for criticality to occur when moderated.

A list of approved pin container loadings where the containers contain any Type B fuel pins shall be maintained by the Criticality Safety Representative and with the Shift Operations Manager's copy of the FSAR, Chapter 20. 
4. Nonfuel Fissionable Material

4.1 Neutron fission chamber detectors containing fissionable material and sealed, unmoderated fissionable sources (including ${ }^{238} \mathrm{Pu}$ ).

B. Operations Involved

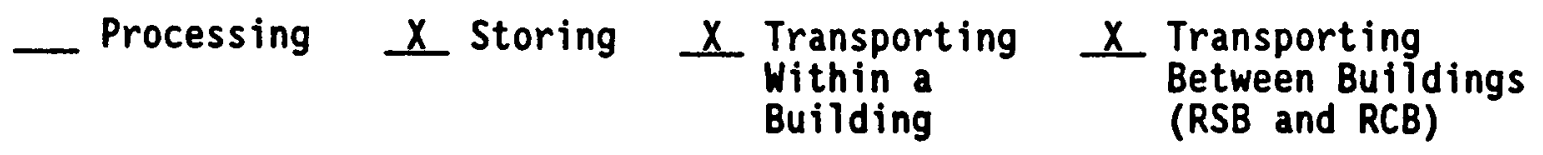

C. Brief Description of Operations and Equipment Involved

1. This specification is valid for the transportation and handling of fresh and irradiated fuel on the 550-ft level of the RSB and RCB and storage of fuel on the 550-ft level of the RCB.

2. This specification is also valid for the storage and handling of fission chamber detectors containing fissionable material out of their permanently installed location in the RCB and for handling sealed, unmoderated fissionable sources.

3. The Limits and Controls section of this specification does not provide limits for the Reactor Vessel, IDS, TACS (note restrictions in Section D.1.4), $\operatorname{CCCS}(\mathrm{N}), \operatorname{CCCS}(S), B L T C$, CLEM, or T-3 shipping cask. Technical Specifications [Chapter 17 of the Fast Flux Test Facility Final Safety Analysis Report, HEDL-TI-75001 ${ }^{(3)}$ ] provide operating limits for the reactor vessel. The Design Controls section of this specification provides assurance of safe operation for the other fuel storage and transfer locations.

4. RRSCs shall not be stacked.

D. Fuel Handling Limits and Controls

1. Limits for Criticality Safety

1.1 Batch Limits--safe amounts of fissionable material. Batch limits are used for transportation of fissionable material 
outside of work stations (Section 20.4.1, Part D.2.3) and for establishing limits in auxiliary work stations (Section 20.4.1, Part D.1.2.2). A batch shall meet at least one of the following criteria applicable to the type of fuel:

1.1.1 Three (max) Radial Reflector Shipping Containers (RRSC). No more than one (max) RRSC containing fuel shall be open. Each shall be limited by one of the following criteria:

- Four (max) Type A assemblies

- Two (max) Type B assemblies and no other fuel assemblies

- One (max) Type B assembly and two (max) Type A assemblies.

1.1.2 Two (max) Instrumented Test Article Shipping Cunlainers (ITASC), each containing nne (max) Typo A or B asscmbly. No more than one ITASC shall be open.

1.1.3 One of the following limits applies to the batch 1 imit for fuel assemblies:

- One (max) Type A assembly

- One (max) Type B assembly.

1.2 Work Station Limits--Uniess otherwise specified, the wnrk. station limit is the sum of each of the bulleted limits.

\subsubsection{CTASS Work Station}

- Inree (max) RRSCs. Each shall be limited by one of the following criteria:

- Four (max) Type A assemblies

- Two (max) Type B assemblies and no other fuel assemblies

- One (max) Type B assembly and two (max) Type A assemblies.

No more than one $(\max )$ RRSC shall be open at any one time.

- One (max) Type A assembly or one (max) Type B assembly not attached to an RRSC strongback 
- Two (max) ITASCs, each containing one (max) Type A or $B$ assembly. No more than one (max) ITASC containing fuel shall be open at any time.

\subsubsection{Auxiliary Work Stations}

- The fuel contained within an auxiliary work station is limited to any one of the batch limits of Section 20.4.1, Part D.1.1.

- One one assembly shall be removed from a strongback at a time.

- No more than two (max) auxiliary work stations shall be established at any one time.

- The Manager, FFTF Operations, shall approve establishing any auxiliary work station.

- Auxiliary work stations may only be established on the 550-ft level in the RCB.

- The work stations shall meet the spacing requirements of Section 20.4.1, Part D.2.1.

\subsection{Moderation Control}

No more than 5 gal of free moderating liquid shall be permitted in a work station, not counting moderators fixed by design, unless all fuel is located in closed shipping containers. If this condition is not met, fuel handling shall be terminated and the moderating liquid removed. Failure to meet this limiting condition is not a CPS nonconformance, but shall be reviewed and reported appropriately. 


\subsection{Facility Restrictions}

1.4.1 Only two Type $A$ assemblies are allowed in the New Storage Vault and two Type $A$ assemblies are allowed in the Radioactive Storage Vault of the TACS.

1.4.2 MFF-8A shall be the only Type $B$ assembly that is inserted into TACS. MFF-8A shall only be stored in TACS CLIRA storage cell T-383, with up to 1 (max) Type $A$ assembly in T-382.

1.4.3 When MFF-8A is stored in TACS CLIRA storage, no fueled assembly(ies) are allowed to be placed in TACS, other than in CLIRA cells.

\section{Controls for Criticality Safety}

\subsection{General Spacing Limits}

2.1.1 A 3-ft (min) edge-to-odgo spacing shall be maintained as follows:

- Between work stations

- Between fuel outside a work station and work stations except for work stations to or from which the fuel is being moved

- Between any two batches outside work stations.

2.1.2 No spacing restrictions are required between work stations and the permanent fuel storage locations and transfer equipment specified in Section 20.4.1, Part C.3. 


\subsection{Inventory}

2.2.1 A current inventory of fissionable material shall be maintained. Standard inventory control records maintained by FFTF Refueling and Maintenance Planning will satisfy this requirement.

\subsection{Transportation of Fuel Outside Work Stations}

2.3.1 Any fuel moved outside established work stations, except fuel in the permanent equipment designated in Section 20.4.1, Parts F.1 through F.7, shall meet one of the batch limits of Section 20.4.1, Part D.1.1.

2.3.2 The spacing restrictions of Section 20.4.1, Part D.2.1, shall be adhered to.

2.3.3 Only one batch shall be transported per person, cart, or vehicle.

2.3.4 No more than one batch shall be in transit at any one time in the RSB and one in the RCB.

[. Nonfuel rissionable Material Liiiit

The total quantity of nonfuel fissionable material shall not exceed $50 \mathrm{~g}$. This material shall be in the form of radiation sources and fission chambers.

F. Design Controls

By respective equipment designs, adherence to the following limits is ensured. Fuel located in the equipment specified in items 1 through 7 below is in a safe configuration by virtue of the design. It is, 
therefore, not governed by either the batch or work station limits or controls of Section 20.4.1, Part D.1.

1. The Closed Loop Ex-Vessel Machine (CLEM) is 1 imited to handling one (max) Type $A$ or $B$ fuel assembly, Ident 69 containing fuel pins, or Ident 1578 containing fuel pins.

2. The Bottom Loading Transfer Cask (BLTC) is limited to one (max) Type $A$ or $B$ fuel assembly, Ident 69 containing fuel pins, or Ident 1578 containing fuel pins.

3. Each T-3 shipping cask is limited to one (max) Type $A$ or $B$ fuel assembly, Ident 69 containing fuel pins, or Ident 1578 containing fuel pins.

4. Each core component storage location in the IUS array is limited to one (max) Type A or B fuel assembly, Ident 69 containing fuel pins, or Ident 1578 containing fuel pins.

5. Each location in the TACS is limited to one (max) $40-\mathrm{ft}$ fuel assembly. The TACS is not designed to accept Ident 69 pin containers, or 1578 pin containers. Although the TACS was not originally designed to accept 12-ft assemblies, they may be stored in the TACS CLIRA storage cells using an adapter tube(s). (Note the limit in Section 20.4.1, Parts D.1.4.1 and D.1.4.3, that limits the number of assemblies in the New and Radioactive Storage Vaults, and Part D.1.4.2, that limits the insertion of Type $B$ assemblies in the TACS.)

6. Each of the two locations in Core Component Conditioning StationSouth (CCCS[S]) is 1 imited to one (max) Type A or B fuel assembly, Ident 69 containing fuel pins, or Ident 1578 containing fuel pins.

7. The CCCS-North $(N)$ is limited to one (max) Type A or B fuel assembly, Ident 69 containing fuel pins, or Ident 1578 containing fuel pins.

8. Each Ident 1578 is 1 imited to 40 (max) Type A fuel pins. 


\section{Ident 69 and Ident 1578 Pin Containers Containing Fue 1 Pins}

3.1 Ident 1578 pin containers containing Type A fuels pins.

3.2 Ident 69 pin containers containing no more than 217 Type A fuel pins.

3.3 Ident 1578 and Ident 69 pin containers containing any Type B fuel pins where the pin container loading has been approved and found to be no more reactive than a Type $A$ assembly when unmoderated and greater than three pin containers are necessary for criticality to occur when moderated.

A list of approved pin container loadings where the containers contain any Type $B$ fuel pins shall be maintained by the Criticality Safety Representative and in the Shift Operations Manager's copy of FSAR, Chapter 20.

\section{Nonfuel Fissionable Material}

4.1 Neutron fission chamber detectors containing fissionable material and sealed, unmoderated fissionable sources (including ${ }^{238} \mathrm{Pu}$ ).

B. Operations Involved

$\underline{x}$ Processing $\underline{x}$ Storing $\underline{x} \begin{aligned} & \text { Transporting } \\ & \text { Within a } \\ & \text { Building }\end{aligned} \quad \begin{aligned} & \text { Transporting } \\ & \text { Between } \\ & \text { Buildings }\end{aligned}$

C. Brief Description of Operations and Equipment Involved

1. This specification is valid for the transportation and handing of fresh and irradiated fuel within the IEM Cell.

2. Any assembly duct containing fuel pins shall be counted as one fuel assembly. 
3. Fuel pins shall not be intentionally disassembled to release fuel pellets or powder. If such a release should occur, all pins and assemblies shall be placed in a secure position, and the released fuel shall be cleaned up before resuming normal operations.

\section{Fuel Handling Limits and Controls}

\section{Limits for Criticality Safety}

\subsection{Fuel Storage Locations [Except Ident 35 and Pin Weighing System $(M-715)]$}

Each of the fuel storage locations listed in Table 20.4-1 shall contain no more than the stated amount of fuel.

\begin{tabular}{|c|c|c|c|c|c|}
\hline \multicolumn{6}{|c|}{ TABLE 20,4-1 } \\
\hline \multirow[b]{2}{*}{$\begin{array}{l}\text { Ident } \\
\text { No. }\end{array}$} & \multirow[b]{2}{*}{ Location Description } & \multicolumn{4}{|c|}{ May Contain One of the Following: } \\
\hline & & $\begin{array}{l}\text { Fuel } \\
\text { Assy }\end{array}$ & $\begin{array}{l}\text { Closed } 69 \\
\text { w/Fuel Pins }\end{array}$ & $\begin{array}{l}\text { Closed } 1578 \\
\text { w/Fuel Pins }\end{array}$ & $\begin{array}{l}\text { Closed } 1578 \\
\text { Pin Basket } \\
\text { w/Fuel Pins }\end{array}$ \\
\hline 15 & $\begin{array}{l}\text { Core Component } \\
\text { Receiving Container }\end{array}$ & 1 & 1 & 1 & --- \\
\hline 89 & $\begin{array}{l}\text { Sodium Removal } \\
\text { Station }(T-100)\end{array}$ & 1 & --- & --- & 1 \\
\hline $17-1$ & $\begin{array}{l}\text { Cure Component } \\
\text { Pot Storage Container }\end{array}$ & 1 & 1 & -- & --- \\
\hline $17-2$ & $\begin{array}{l}\text { Core Component } \\
\text { Pot Storage Container }\end{array}$ & 1 & 1 & -- & --- \\
\hline $39-1$ & $\begin{array}{l}\text { Fuel Pin Shipping } \\
\text { Container Rack }\end{array}$ & 1 & 1 & --- & -- \\
\hline $39-2$ & $\begin{array}{l}\text { Fuel Pin Shipping } \\
\text { Container Rack }\end{array}$ & 1 & 1 & -- & -- \\
\hline 41 & $\begin{array}{l}\text { Duct } \\
\text { Measuring System }\end{array}$ & 1 & -- & --- & --- \\
\hline $116 B$ & $\begin{array}{l}\text { Fuel Pin Container } \\
\text { Transfer Stand - } \\
\text { Wall-Mounted } \\
\text { Manipulator }\end{array}$ & 1 & 1 & 1 & 1 \\
\hline
\end{tabular}


3.3 Closed Ident 1578 and Closed Ident 69 pin containers containing any Type $B$ fuel pins where the pin container loading has been approved and found to be no more reactive than a Type $A$ assembly when unmoderated and greater than three pin containers are necessary for criticality when moderated.

A list of approved pin container loadings where the containers contain any Type $B$ fuel pins shall be maintained by the Criticality Safety Representative and in the Shift Operations Manager's copy of FSAR, Chapter 20.

\section{Nonfuel Fissionable Material}

4.1 Neutron fission chamber detectors containing fissionable material and sealed, unmoderated fissionable sources (including ${ }^{238} \mathrm{Pu}$ ).

B. Operations Involved

- Processing $\underline{x}$ Storing $\underline{x} \underset{\substack{\text { Within } \\ \text { Building }}}{\text { Transporting }}-\begin{gathered}\text { Transporting } \\ \text { Between Buildings } \\ \text { (RSB and FSF) }\end{gathered}$

C. Brief Description of Operations and Equipment Involved

1. The only fuel handling operations permitted by this specification are (1) transfer of fuel in the BLTC between the RSB and the FSF Storage Vessel and (2) storage of fuel in the FSF Storage Vessel.

2. This specification is also valid for the storage and handling of fission chamber detectors containing fissionable material and for handling sealed, unmoderated fissionable sources. 


\section{Fuel Handling Limits and Controls}

1. Limits for Criticality Safety--All fuel in the FSF shall be either in the BLTC or in the FSF Storage Vessel, which are safe by their design features. Therefore, no batch limits or Work Station limits are applicable to FSF.

\section{Controls for Criticality Safety}

2.1 General Spacing Limits--Because all required spacing is guaranteed by the Design Controls (no batches or Work Stations are permitted), there are no applicable spacing 1 imits.

2.2 Inventory--A current inventory of fissionable material shall be maintained. Standard inventory control records maintained by FFTF Refueling will satisfy this requirement.

\section{E. Nonfuel Fissionable Material Limit}

The total quantity of nonfuel fissionable material shall not exceed $50 \mathrm{~g}$. This material shall be in the form of radiation sources and fission chambers.

F. Design Controls

1. Physical Design Restrictions--By respective equipment designs, adherence to the following limits is assurud.

1.1 The Bottom Loading Transfer Cask (BLTC) is limited to one $(\max )$ fuel assembly, Ident 69 containing fuel pins, or Ident 1578 containing fuel pins.

1.2 Each core component storage location in the FSF Storage Vessel array is limited to one (max) fuel assembly, Ident 69 containing fuel pins, or Ident 1578 containing fuel pins. Access to Rows $H, J$, and $M$ is physically restricted.

\subsection{Deleted.}




\subsection{CRITICALITY PREVENTION SPECIFICATION BASES}

\subsubsection{Technical Bases for CPS 405-1, 550-ft Level of RCB and RSB}

Work Location: This specification permits handling greater than one-third Minimum Critical Mass in the RCB and RSB.

\section{A. Fissionable Material Description}

1. Fuel Pins

2. Assemblies

The original FFTF Criticality Specifications did not address specific fuel assemblies, but rather bounded the fissionable material descriptions of fuel assemblies and pins. Analyses were performed, and limits established, based on an assembly with Driver Fuel Assembly (DFA) (Series I/II) dimensions and a $\mathrm{PuO}_{2}$ enrichment of $\leq 31$ wt\%. The content of ${ }^{240} \mathrm{Pu}$ was analyzed to be $10 \mathrm{wt} \%$.

Assemblies, other than Series I or II DFAs, are analyzed with respect to this 31 wt\% DFA. Irrespective of their fuel form or interior dimensions, assemblies no more reactive than the 31 wt\% DFA are categorized as Type $A$ assemblies. Type $A$ assemblies have an MCN of at least 5 and are handled under a batch limit of one (max) assembly. All Series I and II DFAs are Type A assemblies and do not need to be reanalyzed.

Type B assemblies are more reactive than Type $A$ assemblies and are handled under a batch limit of one (max) assembly. Reference 15 provides additional information on the criteria for these categories.

Fuel pins are categorized in the same manner. Only pins that will be outside of assembly ducts are described in this section. A pin no more reactive than a pin with the dimensions of a Series I/II 
DFA fuel pin and enriched to 31 wt\% is a Type A fuel pin. A Type B pin is more reactive than a Type $A$ pin. Unlike the assembly criteria, there is no upper bound on the reactivity of a Type $B$ fuel pin. That is acceptable, because the limits are not preestablished for Type B pins. When they are so designated, appropriate limits have to be provided case by case.

The categorization of fuel pins and assemblies as Type $A$ and $B$ permits a formal, two-tiered approach to fuel handing analyses.

1. Before handling fuel assemblies or pins, they are analyzed to determine if they are Type $A$ or $B$. Type $A$ assemblies and pins do not require any C.PS r.hanges. However, a l1sting of Type $A$ assemblies is maintained with the Criticality Safety Representative and in the Shift Operations Manager's copy of FSAR, Chapter 20 for the aid of the operators and for auditability.

2. A second level of effort is required for the Type B assemblies and pins.

\section{Iype B assemblies:}

- Require a change to CPS 405-1 for increased visibility that the: more restrictive Type $B$ limits apply

- Cannot be handled in the TACS, the IEM Cell (CPS 405-2), or the FSF (CPS 403-1) without a CPS change not only listing them, but also providing appropriate limits.

Type B pins:

- Require a change to CPS 405-2 for the IEM Cell listing them and providing new limits (or verifying that current limits are satisfactory) 
- Require explicit pin container loading plans to ensure the pin containers remain within the reactivity criteria of Type $A$ assemblies when unmoderated and greater than three pin containers are necessary for criticality to occur when moderated. 
station boundaries, it must meet one of the batch limits. Each of the batch limits is a safe amount of fuel, even fully moderated in its most reactive configuration.

\subsection{Batch Limits}

1.1.1 Nine (9) RRSCs with their permitted loading (four standard assemblies each) cannot (with optimum moderation and spacing) be made critical. The batch limit of three was chosen as the limit to control the amount of fuel on hand, and because it is less than $1 / 3$ of the critical number (CN). The RRSCs should normally be closed to maintain cleanliness and as a preventive measure for inadvertent moderation. Reference 15 provides the technical basis for the contents of each RRSC with respect to Type A and B assemblies.

1.1.2 The minimum CN of ITASCs containing fuel is 288 . The batch limit of two was chosen as a number that would not be operationally restrictive.

1.1.3 Table 20.5-1 shows criticality data taken from References 4 and 5. The MCN of DFAs is 5. This is the smallest number that can be made critical for optimum moderation and full reflection. Without moderation, the MCN is at least 27 DFAs for pins containing 31 wt\% $\mathrm{Pu}\left({ }^{240} \mathrm{Pu}=10\right.$ wt\%) $\mathrm{O}_{2}-U($ nat $) \mathrm{O}_{2}$. A limit of one assembly is $<1 / 3$ of the MCN and $4 \%$ of the unmoderated $\mathrm{CN}$.

For Type B assemblies, because their MCN is at least three, one is the appropriate batch limit.

Type $B$ assemblies with $0.33 \mathrm{MCN}$, but no more than 0.45 of their $\mathrm{CN}$, can be handled on a temporary basis, with alarm coverage provided by a portable CAS. If justification is provided by a specific 20.5-5 
analysis that a criticality is not possible based on physical form and isotopic distribution of fissionable material, 0.45 of MCN may be handled as a batch of one assembly without alarm coverage.

\subsection{Work Station Limits}

Work stations described in this section may contain fuel under specified conditions in excess of one batch. Fuel shall not be moved into a work station unless it is first verified that the work station limits will not be exceeded. Fuel leaving a work station shall meet one of the batch limits of Section 20.4.1, Part D.1.1.

\subsubsection{CTASS Nork Station}

The CTASS has two main purposes: (1) to provide a location for securing 40-ft assemblies after they are unloaded from ITASCs before being loaded in TACS and (2) to provide a location for unloading 12-ft assemblies from RRSCs.

This work station permits the uninading of 12-ft fuol assemblies from RRSCs for loading into CCCS(S). Three RRSCs are permitted, one of which may be opened for unloading. Only one fuel assembly may be handled at any one time. If the only assomblies at CTASS were Type $A$ assemblies, the most reactive credible accident would be to drop one assembly on top of an open RRSC containing four assemblies while at the same time filling the lower half of the RRSC with water.

This would actually constitute two independent accidents. Two assemblies would then be fully moderated, while three assemblies would be unmoderated. 
Optimum moderation and full reflection would require flooding of the entire area to a depth of $>20$ in. This is not possible. In the postulated accident, very little reflection would be available on the top half of the container. Steel plates of $0.25-i n$. thickness separate the assemblies. At least five assemblies under optimum conditions are required for criticality. The four assemblies on a completely flooded strongback would have a $k_{\text {eff }}$ of 0.81 . For flooding of only the lower half, $k_{\text {eff }}$ would be much less. For the accident conditions described above, the fuel would remain well subcritical. This would remain true even if two sealed RRSCs were located nearby. Interaction with the assembly secured to CTASS or those in ITASCs would be negligible. Fuel assemblies will be handled with the polar crane and will be removed individually from the work station under the batch 7 imit given in Section 20.4.1, Part D.1.1.3.

If the two independent accidents described above were to occur with a Type B assembly at CTASS, and if the Type B assembly was the assembly that was dropped, the result would be two driver assemblies fully moderated and the Type B assembly plus two driver assemblies unmoderated. It is conservative to use two driver assemblies in the place of the Type $B$ assembly. The result then becomes equivalent to two driver assemblies moderated and four driver assemblies unmoderated. If the Type $B$ assembly was in the lower part of an RRSC when the accidents occurred, the result would be the equivalent of three driver assemblies fully moderated and three driver assemblies unmoderated. No reflection would be supplied over the upper half of this array and only partial reflection around the lower portion. In neither case could a criticality occur as 5 driver assemblies under optimum conditions or 31 driver assemblies in air are required 
for criticality. The sum of the fractions of critical would not exceed 0.85 in the most reactive combination.

\subsubsection{Auxiliary Work Stations}

Auxiliary work stations may be established to safely handle unforeseen circumstances. To ensure control while providing this flexibility, the number of such stations is limited to two, and the FFTF Operations Manager must approve the establishment of each. Each auxiliary work station is limited to one batch and must meet the spacing and posting requirements applicable to all work stations.

\subsection{Moderation Control}

Because all of the operations with fuel have been shown to be subcritical when flooded, the limitation on moderating liquid is specified as a rondition for continuing fucl handling rather than a strict criticality limit.

A limit of $5 \mathrm{gal}$ of free moderator is presented as a guideline. Even if this limit is greatly violated, criticality is not possible. However, it is necessary to have a restriction on moderation to maintain a high level of safety. This limit is primarily intended to impress upon fuel handlers that water and other moderators should not be brought near fuel, while at the same time permitting some liquids. No inventory sheet is required, because a visual estimate of volume is sufficiently accurate to satisfy the intent of this limit. This limit of $5 \mathrm{gal}$ was chosen to permit easily portable amounts for required cleanup. There is no known need for greater amounts. 


\subsection{Facility Restrictions}

1.4.1 The TACS has been verified safe for Type $A$ assemblies. However, neither the Radioactive Storage Vault nor the New Storage Vault have been actually shown to meet all requirements for Seismic Category I. Therefore, each of these vaults is limited to two (max) Type A assemblies. This restriction may be removed upon showing that the array supports and grid plates are Seismic Category I or by showing that moderation is not credible.

1.4.2 MFF-8A is the only Type $B$ assembly that is approved for storage in any TACS location. An analysis has been performed that shows MFF-8A (which is a Type B assembly) may be $p l a c e d$ into TACS CLIRA storage (location T-383) either alone or with only 1 other Type A assembly (max) in the CLIRA storage area (location T-382).

1.4.3 The analysis for MFF-8A was performed with the Radioactive Storage Vault full of nonfueled MOTA assemblies and the New Storage Vault empty. Before any fueled assemblies, other than those already approved in Section 1.4.2, are stored anywhere in TACS, an analysis must be performed verifying the safe storage of the assemblies in these locations.

\section{Controls for Criticality Satety}

\subsection{General Spacing Limits}

The 3-ft spacing (required for operation without a CAS) ensures. no reactivity effects between work stations and/or batches. This spacing limit could be violated by several batches simultaneously without causing criticality, assuming that at the same time moderation is not provided. Storage locations and handling machines listed in Section 20.4.1, Part C.3, are inherently safe by design. Fuel in any of these locations cannot be physically brought within $3 \mathrm{ft}$ of fuel in any other specified location. In addition, a batch of fuel being moved independently of these locations cannot be brought accidentally within $3 \mathrm{ft}$ of fuel within these locations, except when being

$$
\text { 20.5-9 }
$$

Amendment 72, 08/15/92 132542,167102 , Text Rotation 
entered into one of those locations. Fuel being entered becomes part of the limit for that location and must fall under the appropriate limit. If a location already contains a limit quantity, equipment design prevents the addition of more fuel.

\subsection{Inventory}

Maintaining a current inventory using the standard inventory control records meets the requirements of WHC-CM-4-29. (1)

\subsection{Transportation of Fuel Outside Work Stations}

One bateh of fuel is permittud lo be transported outside of work stations at any one time. Note that fuel in the permanent equipment designated in Section 20,4.1. Parts F.1 through F.7, is not considered under batch limits. Although an unl imited number of batches could be in transit using the above limits with no criticality hazard, this limit reduces the potential for a batch size or spacing limit violation. The consequences of violating these limits is discussed in Section 20.5.1, Parts D.1.1 and D.2.1. The one batch limit per person, cart, or vehicle reduces the possibility of a limit violation caused by a common mode failure and is consistent with the double contingency principle.

\section{E. Nonfuel Fissionable Material Limit}

The 50-g limit on nonfuel fissionable material is intended to cover handling of radiation sources and fission chambers without having to place them on the inventories of the various work stations. Radiation sources and fission chambers generally each contain $<3 \mathbf{g}$ of fissionable material. Their construction makes it difficult to combine them with fuel assemblies or pins in such a way as to cause effective interaction. Moderating materials associated with them are limited to small quantities of solids and cannot be effectively combined with other fissionable material. The entire quantity of nonfupl fissionable material under conditions of optimum moderation and full reflection comprises $<10 \%$ of a minimum critical mass. In reality, it is considerably less. In practice, this material will be located in small units in widely separated locations. At least four Type A assemblies or three Type $B$ assemblies together with moderation and all $50 \mathrm{~g}$ of nonfuel 
fissionable material would have to be combined in the presence of full reflection. This is not considered credible.

The 50-g limit on nonfuel is completely independent of the fuel limit. That is, some or all of it may be moved inside work stations and need not meet any spacing restrictions with respect to batches of fuel. A core one or two outer driver fuel pin contains $<40 \mathrm{~g}$ of fissionable material. This 1 imit, then, permits the equivalent of adding about $11 / 4$ driver fuel pins to each work station and batch limit. This does not have a significant effect on those limits. The 50-g limit is a total amount for the RSB and RCB. Buildings at the FFTF other than the RSB/RCB and FSF are limited to $15 \mathrm{~g}$, unless they are established as isolated or nuclear facilities. The 50-g limit is primarily expected to cover fission chambers outside of their permanent wells, check sources (check sources $\leq 0.5 \mathrm{~g}$ need not be maintained on inventory sheets), and radiography sources brought in on temporary basis. The fission chambers for the low-level flux monitors have $2.3 \mathrm{~g}$ of fissionable material. Those for the ex-vessel flux monitors have about $1.1 \mathrm{~g}$.

Some trans-plutonium isotopes have a minimum critical mass $<50 \mathrm{~g}$. However, all of these exist in very small quantities, and their presence at the FFTF in a separated condition in greater than milligram quantities is incredible. These isotopes are not excluded in the specification because of the incredibility of their presence at the FFTF and the benefit of keeping the specification as simple as possible.

\section{F. Design Control}

Limits listed in this section cannot be exceeded because of design features of the equipment. These limits, which do not depend on procedural control, are listed for completeness. Because the equipment in Section 20.4.1, Parts F.1 through F.7, maintains the fuel subcritical by virtue of design, it is not governed by the batch or work station limits and controls. 
Although the IDS vessel was designed safe for FFTF reference fuel assemblies, separate analyses were required for subsequent, more reactive Type $B$ assemblies. Using more recent analyses, a complex limit could have been written within the specification. It was decided, rather, to continue to state that the IDS is designed safe for those assemblies approved for use at the FFTF. Therefore, this list of approved assemblies (see Section 20.4.1, Part A.2, of the specification) includes a statement that any combination of approved assemblies loaded into the IDS would result in an IDS $k_{\text {eff }}<0.95$ at the 2-sigma confidence level. Because all pin containers are loaded (CPS 405-2, Part A.3) to be no more reactive than Type $A$ assemblies when unmoderated, they do not need to be listed separately.

The TACS has been verified safe for Type $A$ assemblies. However, neither the Radioactive Storage Vault nor the New Storage Vault have been actually shown to meet all requirements for Seismic Category I. Therefore, each of these vaults is limited to two (max) Type A assemblies: This restriction may be removed upon showing that the grid plates are Seismic Category I or by showing that moderation is not credible. Because an analysis of Type $B$ assemblies in the TACS has not been performed except for MFF-8A, it is limited to Type $A$ assemblies and MFF-8A. The TACS is not designed to accept Ident 1578 and Ident 69 pin containers. Therefore, no analysis is necessary for moderated pin containers in the TACS. Twelve-foot assemblies may be stored in the TACS CLIRA cells using adapter tubes.

\subsubsection{Technical Bases for CPS 405-2. IEM Cell}

\section{Bases, Limits, and Controls}

Introduction: In an unmoderated environment, the MCN of pins and assemblies permitted by Section 20.5.2, Part A, is 1,785 (clad-to-clad) Type A pins or 27 Type $A$ assemblies. It is impossible to achieve criticality within the stated limits (even if physical constraints fail) in an unmoderated environment. The MCN of Type $B$ assemblies and pins are evaluated on a caseby-case basis.

$20.5-12$

Amendment 72, 08/15/92 132542,167102 ,

Text Rotation 
The double-contingency policy (Section 20.3.1) states that at least two unlikely, independent, and concurrent events must occur before criticality is possible. The two events required for a criticality in the IEM Cell are as follows:

(1) An event that removes the allowable fuel in the cell from engineered constraints and places it in a configuration required for criticality when moderated

(2) An event permitting sufficient moderating material in the cell.

Each of these events is extremely unlikely. Their simultaneous occurrence is incredible. The remainder of the bases will demonstrate how adherence to the specification limits ensures the very low probability of each of these events.

Work Location: This specification permits handling quantities of fissionable material greater than $1 / 3$ Minimum Critical Mass in the IEM Cell.

\section{A. Fissionable Material Description}

\section{Fuel Pins}

\section{Assemblies}

The original FFTF Criticality Specifications did not address specific fuel assemblies, but rather bounded the fissionable material description of fuel assemblies and pins. Analyses were performed, and limits established, based on an assembly with DFA (Series I/II) dimensions and a $\mathrm{PuO}_{2}$ enrichment of $\leq 31 \mathrm{wt} \%$. The content of ${ }^{240} \mathrm{Pu}$ was analyzed to be $10 \mathrm{wt} \%$.

Assemblies, other than Series I or II DFAs, are analyzed with respect to this 31 wt\% DFA. Irrespective of their fuel form or interior dimensions, assemblies no more reactive than the 31 wt\% DFA are categorized as Type $A$ assemblies. Type $A$ assemblies have an MCN of at least 5 and are handled under a batch limit of two (max) 
assemblies. All Series I and II DFAs are Type A assemblies and do not need to be reanalyzed.

Type $B$ assemblies are more reactive than Type $A$ assemblies. They have an MCN of at least 3 and are handled under a batch limit of one (max) assembly. Reference 15 provides additional information on the criteria for these categories.

Fuel pins are categorized in the same manner. Only pins that will be outside of assembly ducts are described in this section. A pin no more reactive than a pin with the dimensions of a Series I/II DFA fuel pin and enriched to 31 wt\% is a Typo A fuel pin. A Type B pin is more reactive than a Type $A$ pin. Unlike the assembly criteria, there is no upper bound on the reactivity of a Type $B$ fuel pin. That is acceptable, because the limits are not preestablished for Type B pins. When they are so designated, appropriate limits have to be provided case by case.

The categorization of fuel pins and assemblies as Type $A$ and $B$ permits a formal, two-tiered approach to fuel handling analyses.

1. Before handling fuel assemblies or pins, they are analyzed to determine if they are Type $A$ or $B$. Type $A$ assemblies and pins do not require any CPS changes. However, a listing of Type $A / B$ assemblies is maintained with the Criticality Safety Representative and in the Shift Operations Manager's copy of the FSAR, Chapter 20 for the aid of the operators and for auditability.

2. A second level of effort is required for the Type B assemblies and pins:

\section{Type B assemblies:}

- Require a change to CPS 405-1 for increased visibility that the more restrictive Type B limits apply 
- Cannot be handled in TACS, IEM Cell (CPS 405-2), or FSF (CPS 403-1) without a CPS change not only listing them, but also providing appropriate limits.

Type B pins:

- Require a change to CPS 405-2 for the IEM Cell listing them and providing new limits (or verifying that current limits are satisfactory)

- Require explicit pin container loading plans to ensure the pin containers remain within the reactivity criteria of Type $A$ assemblies when unmoderated and greater than three pin containers are necessary for criticality to occur when moderated.

Whenever a change is made to the $A / B$ assembly list, a statement is provided that any combination of approved assemblies loaded in the IDS would result in an IDS $k_{\text {eff }}<0.95$ at the 2-sigma confidence level.

Two specific types of pins have been excluded from criticality control at the FFTF.

(1) Some assemblies have contained fissionable material foils, where the fissionable material has been present on the milliand microgram level. Pins containing $<100 \mathrm{mg}$ of fissionable material may be considered nonfuel pins.

(2) Blanket assemblies contain ${ }^{235} \mathrm{U}$ in depleted or natural uranium. While unirradiated, these can be considered nonfuel assemblies.

3. The purpose of this section is to ensure that Ident 69 and Ident 1578 pin containers are loaded such that they can be handled safely in the IEM Cell and within the limits of CPS 405-1 and 403-1. The only difference between the pin container section 
(Part A.3) of CPS 405-1, 405-2, and 403-1 is that the IEM Cell CPS 405-2 permits the containers to be open. 
In an unmoderated condition, these pin containers are to be no more reactive than Type $A$ assemblies. This means they can be stored in either the IDS storage array or the FSF storage array without further analyses. When moderated, however, pin containers can be more reactive than Type $A$ assemblies. This is satisfactory, provided that greater than three containers are necessary for a criticality to occur (see Reference 11). The only credible locations for moderation are the IEM Ce11, CCCS, and TACS. Accidental moderation in the IEM Cell is extremely unlikely (see Section 20.5.2, Part D.1.6). Neither CCCS can hold more than two pin containers or assemblies. The TACS is not designed to accept Ident 1578 or Ident 69 pin containers (see Section 20.4.1, Part F.5).

3.1 Reference 8 provided the original analysis for the Ident 1578 pin containers. The Ident 1578 has two basket inserts, one with a capacity of 19 pins and the other of 40 pins. For moderated and unmoderated conditions, the Ident 1578 is less reactive than a DFA.

3.2 The Ident 69 analyzed by Reference 8 has 109 pin tubes. Since that time, several other models have been developed. The following paragraphs trace the development of the Ident 69 models and the analyses that have been completed and led to the current limits.

Following the design and analysis of the original Ident 69 , several other designs were made to accommodate the distorted, irradiated pins that would not fit into the original container with 109 tubes. The Ident $69 \mathrm{~A}$ has 55 larger-diameter pin tubes and, as do all the Ident 69 models, uses the same "shell." A 37-pin tube configuration was also designed and has been designated Ident 69B. Reference 9 provided the analysis covering these pin configurations. 
Following the disassembly of DE-3-1, a new design was developed that would allow the Ident 69 to hold a greater number of the distorted pins (more than 37 or 55). The Ident $69 \mathrm{C}$ was designed to have only seven large compartments: a center circle with the surrounding space divided at $60^{\circ}$ intervals. The operating philosophy is to place as many fuel pins in each compartment as possible.

Although the previous analyses showed that what was specifically being considered was safe, at this point it was decided to perform a "bounding analysis" for the Ident 69. In this analysis, (11) it was most consorvative to consider that there was no restricting internals in the Ident 69 . It has been theoretically determined that a maximum nf 283 drivor fuel pins with wire wrap, or 451 without wire wrap, could be inserted into an Ident 69 shell.

For operations in the IEM Cell, normal and accident conditions were considered. Under normal conditions, where the pins are contained within the pin container in an unmoderated condition, the number of pine is $<45 \%$ of the MCN and call be handled safely. Under accident conditions, neither the configuration nor the lack of moderator are certain. Without moderator, those pins by themselves cannot increase in reactivity by coming out of the container, because the more loose the pack, the less reactive the configuration. Even proximity to other fuel in the IEM Cell under accident conditions, when unmoderated, cannot cause a criticality. For moderated conditions, increasing the number of fuel pins in an Ident 69 above the previously authorized limit of 109 does not significantly increase the reactivity of the Ident 69. As the number of fuel pins is increased, the amount of interstitial moderator is decreased, thereby reducing the 
effectiveness of the moderator. Therefore, the only potential of a criticality is the concurrent loss of configuration control of the fuel and the presence of a large amount of moderator. Because the probability of either of these events is extremely low (see Section 20.5.2, Introduction, and Section 20.5.2, Part D.1), this is satisfactory. Increasing the allowable number of pins in an Ident 69 does not significantly increase the probability of an accidental criticality. Therefore, a limit has been placed on the Ident 69 loading such that they contain no more than 217 Type A fuel pins. This will be conservative because virtually all of the fuel assemblies in the IEM Cell will have lower enrichments $(<31 \%)$ and have even lower reactivity because of their irradiation.

3.3 Type $B$ pins are more reactive than driver fuel pins enriched to 31 wt\% (Type A pins). Therefore, when Type B. pins are loaded, an evaluation is required to verify that the loading is no more reactive than a Type $A$ assembly when unmoderated or when moderated greater than three pin containers are required for criticality.

4. This specification also places a limit on fissionable material in fission chambers and unmoderated fissionable sources. These will not significantly affect the degree of criticality safety within the IEM Cell.

\section{B. Operations Involved}

This specification covers receipt, storage, cleaning, handling, and transfer of pins and assemblies and disassembly of assemblies. It does not cover operations involving the fuel pellets or powder (prohibited under Section 20.4.2, Part C.3). 


\section{Brief Description of Operations and Equipment Involved}

1. This specification permits both fresh and irradiated fuel in the IEM Cell. The concern of this specification is criticality control. Limits on the total decay heat of irradiated fuel are in Chapter 17 of the FSAR Technical Specifications, ${ }^{(3)}$ Section 17.3.7.2.3.

2. This specification does not consider partial fuel assemblies with respect to limit Section 20.4.2, Part D.1.1. For example, an assembly with half fuel pins and half stainless steel shall be considered as one fuel assembly, not as half a fuel assembly.

3. Although disassembly of assemblies and, to some extent, of pins is planned in the IEM Cell, the clad boundary shall not be intentionally opened. In-cell operations with pins whose cladding has failed may continue in accordance with the conditions of Section 20.4.2, Part D.2.1. Releases from failed fuel pins would not result in more than small quantities ( $<15 \mathrm{~g})$ of pellets or powder being introduced into the. IEM Cell. This material would not be allowed to accumulate but would be cleaned up prior to resuming operations.

\section{Fuel Handling Limits and Controls}

\section{Limits for Criticality Safety}

The "Limits for Criticality Safety" restrict fuel storage locations to the physical constraints designed to store fuel. While it is not envisioned that all such locations would be used simultaneously, to do so would be safe from a criticality safety standpoint. All storage locations in the Cell restrain the fuel in a vertical configuration above the floor level. The bases for this section will demonstrate that if a seismic event occurred (an unlikely event) that caused all fuel constraints to fail (another unlikely event), the probability of the fuel falling in a configuration that would permit a criticality, if moderated, would also be very small. 
In addition to weekly radioactivity analyses of the filters in the inerted cell aerosol monitors, another means of detecting radioactive primary sodium in the inerted cells during power operation is by monitoring particulate filters in the sample lines for the Nitrogen Atmosphere Sampling and Analysis (NASA) System. Filters in the sample line from each sampled cell pass a continuous gas stream and are monitored daily with a portable counter during operation in Modes 1 and 2.

The sensitivity of the detection method is estimated in a manner similar to the evaluation of the aerosol filters. Using the same model and terminology, the total activity on a filter at any time $(t)$ is:

$$
R=k Y^{-1} Q C A_{0}\left(I-e^{-Y t}\right)
$$

where

$$
\begin{aligned}
& k=\begin{array}{l}
\text { Fraction }(0.1) \text { of aerosol from cell reaching filter after } \\
\text { plateout losses }
\end{array} \\
& C=\text { Cell aerosol concentration. }
\end{aligned}
$$

With the background activity existing in the vicinity of the NASA System panels, the usable detector sensitivity is about $10^{-8} \mathrm{Ci}$.

With a sample flow of $2,600 \mathrm{~cm}^{3} / \mathrm{min}$, solution of the equation for detectable cell concentration after $24 \mathrm{~h}$ yields $4.0 \times 10^{-13} \mathrm{~g} / \mathrm{cm}^{3}$. The detectable reactor cavity leak is $400 \mathrm{~g} / \mathrm{h}$. For the HTS cells, the detectable leak is $130 \mathrm{~g} / \mathrm{h}$.

5. Atmospheric Gas Analyzers: The nitrogen analyzer system draws a continuous gas sample from the ventilation exhaust of each inerted cell. Each analyzer system monitors a group of cells sequentially so each cell is monitored every $80 \mathrm{~min}$ for oxygen and moisture levels. 